\title{
Freshwater rotifers from Hordaland, western Norway, with a survey of freshwater rotifers previously found in Norway
}

\section{Brit Godske Bjørklund}

Bjørklund BG. 2009. Freshwater rotifers from Hordaland, western Norway, with a survey of freshwater rotifers previously found in Norway. Fauna Norvegica 29: 11-54.

A total of 156 species (or subspecies) of rotifers, mostly non-planktonic, have been identified from freshwater or slightly brackish-water localities in the county of Hordaland; 83 are new to Norway and 24 others are new to the county. One hundred of the species were collected from the two valleys of Eksingedalen and Teigdalen in spring and summer 1967. Samples were taken on the shallow shores of lake-like parts of the rivers, and in pools, tarns and small lakes. Forty more or less euryhaline freshwater rotifers were also collected during studies of slightly brackish-water localities around Bergen in 1963-1969. A number of freshwater rotifers were collected at several localities in and around Bergen in 1968-1970, and on the western part of Hardangervidda. Of those so far identified, 23 are new to Norway and 8 more are new to the county. They are therefore included in the species list. A few additional ones are referred to in the taxonomical notes. All the species are listed with localities and habitat categories, or, in the case of the last-mentioned ones, just the district where they were collected. The paper includes notes, measurements and, in most cases, figures regarding 44 little known, variable or taxonomically problematical species, especially in the genera Cephalodella and Trichocerca. Comments are given on the distribution, abundance and diversity of the species. The paper presents a survey of previous investigations on rotifers in Norway, listing 200 previously recorded freshwater (a few euryhaline) rotifers, giving other names, the authors who recorded the finds and, in most cases, the counties where the species were collected.

Key words: Rotifera, Norway, fresh water, distribution, taxonomy

Brit Godske Bjørklund, Birkelundsbakken 56, NO-5231 Paradis, Norway

Corresponding author: Brit Godske Bjørklund

E-mail: britgobj@tele2.no

Phone: +4755911713 . Mobile: +4799449459

\section{INTRODUCTION}

A number of detailed investigations of, mostly freshwater, rotifers were performed in mainland Norway in the first half of the twentieth century. Both planktonic and non-planktonic species were dealt with. The first was Lie-Pettersen (1905), who found 12 more or less euryhaline freshwater species in brackish water around Bergen. Huitfelt-Kaas (1906) collected plankton from several lakes in six counties in southern Norway; 19 of the species were new to Norway. Lie-Pettersen $(1909,1910)$ made more detailed investigations of freshwater rotifers in Norway, and added 108 to the list, which then numbered 139 species.
Some investigations were also made by foreign rotifer specialists on brief visits to Norway. Olofsson (1917) found 17 species on the island of Vardøy in Finnmark, adding three new ones to the list. Varga (1936a, 1936b, 1938) made detailed studies in some lakes in Finnmark. He identified 121 species, adding 44 new ones. Berzins (1952) found four freshwater species, two of them new to Norway, near the river mouth in Aurlandsfjord, Sogn \& Fjordane. Thomasson (1956) identified 10 species, including one new one, in two lakes on Dovrefjell, a mountain massif in Sør-Trøndelag.

Several general limnological investigations of plankton have mostly only identified common species. Strøm (1921, 1926, 1927, 1930, 1931, 1932, 1944) recorded 15 rotifer species in 
different parts of the country, but only added one to the list of new species. Hauge (1957) identified 10 species from lakes around Voss, Hordaland, adding one new one. Elgmork (1964) collected plankton in ponds in Buskerud, and added four new ones. Larsson $(1968,1978)$ studied planktonic rotifers in a lake in Akershus, near Oslo, and another in Oppland, and added one new species. Løvik $(1980,1984)$ collected some rotifers among zooplankton from two lakes in Oppland. Koksvik (1985) collected some rotifers in a lake in Hedmark. Reinertsen et al. (1997) collected rotifers during plankton investigations in a lake in Nord-Trøndelag, adding one new species. Wærvågen \& Nilssen (2003) studied planktonic rotifers in lakes in AustAgder and Telemark, adding two new species. Halvorsen et al. (2004) collected rotifers in Atnsjøen, a lake straddling the counties of Oppland and Hedmark, and added one new species.

Hence, with a fairly high degree of certainty, a total of 200 species (or subspecies) of rotifers have been collected in Norway prior to the new ones published in the present paper. The synonym lists of Harring (1913) and Wiszniewski (1954) have been of great help for the oldest records. Segers (2007) has been consulted for valid names and synonyms.

The present author studied rotifers in marine, brackish-water and freshwater habitats in Hordaland in 1963-1970. Only some of the marine and brackish-water material has been published (Eriksen 1968, Bjørklund 1972a, 1972b). A tabulated account of the distribution of species from freshwater habitats in Norway has been published (Bjørklund 1996).

The present paper includes all the identified freshwater species collected in Hordaland in 1963-1970. Most of the investigation took place in two valleys, Eksingedalen and Teigdalen. In addition, species from some slightly brackish-water localities around Bergen are included, as are others new to Hordaland from freshwater pools, small and larger lakes, and a few tarns near Bergen, and some from pools and tarns on the western part of the mountain plateau of Hardangervidda. An updated list of freshwater rotifers previously found in Norway is also included.

\section{MATERIAL AND METHODS}

In summer 1967, the Zoological Museum in Bergen (now Bergen Museum, University of Bergen) initiated investigations in connection with a planned regulation of the lakes and rivers in the valleys of Eksingedalen and Teigdalen. Rotifers were collected at 46 sites, some of them being visited more than once. Most samples were taken from bottom sediment and among submerged vegetation in calm, shallow water using a small rod net with a $45 \mu \mathrm{m}$ mesh. A thin upper layer of the sediment was collected by sweeping just above the bed. The vegetation was swept thoroughly between the plants. A larger plankton net of the same mesh size was used to sample plankton in mountain lakes, a few tarns and a few sites on the rivers. The $\mathrm{pH}$ was roughly determined with a liquid universal indicator. The water temperature was also measured.

The sampling in Eksingedalen took place between the second week of June and the second week of August, inclusive. Teigdalen was briefly visited at the beginning of April, and more comprehensive sampling was done during the second half of August. The material was examined fresh, to observe the rotifers alive and more easily distinguishable from the sediments. Samples of water and sediment were collected in a Petri dish for examination under a stereomicroscope. Many of the rotifers, especially the unknown or uncertain ones, were further examined under an ordinary microscope at magnifications of 500 to $1500 \mathrm{x}$. The loricate forms were killed in formalin before being studied in detail. The illoricate species were studied alive, or after adding small amounts of glacial acetic acid to the side of the cover glass. This mostly narcotised or killed the animal in an extended position. The trophi were studied at the highest magnification after dissolving the other tissues. Representatives of most species were drawn and/or measured by means of a drawing tube to enable precise identification, which in many cases was done later. Some specimens were identified only to the genus level, others not at all. The relative abundance of each species was roughly estimated to one of three levels.

The salinity in the brackish-water localities near Bergen was measured with an aerometer. All the sampling here and in the freshwater localities visited later was done with the small rod net. The $\mathrm{pH}$ and temperature were normally measured. The samples collected on Hardangervidda were fixed in formalin for later examination. The others were examined fresh in the way described above. Representatives of lesser known, or variable species, were drawn and/or measured.

\section{Study area}

Eksingedalen and Teigdalen are fairly narrow valleys surrounded by mountains, and both end in mountainous areas with lakes. The former valley is about $50 \mathrm{~km}$ long, and partly quite steep, even in the lower part. Teigdalen is about $20 \mathrm{~km}$ long, flat at first and then rather steep. The flatter parts of the valleys have calm, mostly shallow, lake-like extensions of the river surrounded by abundant vegetation and also having aquatic vegetation in some parts. Several pools, small lakes, bays and narrow streams were more or less separated from the rivers, depending on the water level. These parts are referred to as river areas, and a few farms were in their vicinity. Spruce, pine, birch and other deciduous trees were common in the lower parts of the valleys, with birch dominating higher up towards the barren mountains.

The spring and summer of 1967 were rather cold and wet, and the water level was quite high throughout the summer, but with 


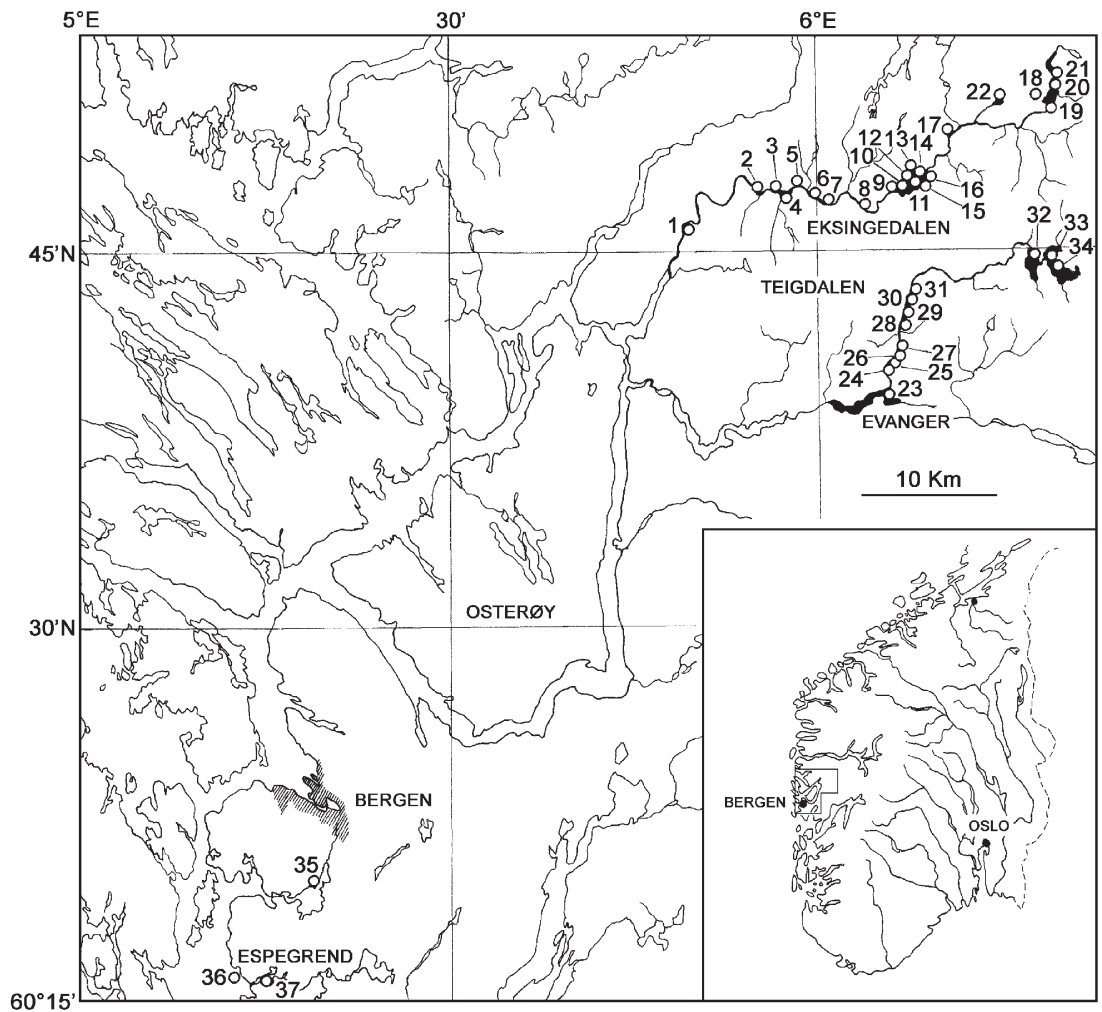

Figure I. Map of the investigated area showing 37 localities between $60^{\circ} 15$ $\mathrm{N}$ and $5^{\circ} 23^{\prime}$ E. Loc. 38 is just northwest of this area. sudden variations. Conditions along the shores became unstable then, and parts of the shores and bordering meadows were mostly more or less flooded. The mountain lakes were situated 760-959 $\mathrm{m}$ a.s.l. Some ice floes and surrounding snow patches and snowfields were seen, even in July and August.

The localities with slightly brackish water are situated around Bergen. Some were shore pools on small islets outside the Biological Station at Espegrend, some in two landlocked fjords, and one was a small inlet.

The main localities are shown and numbered on the map (Figure 1). Some closely situated sampling sites within a given locality are denoted by $a, b$ and $c$ attached to that number. The small, brackish, marshy inlet, Paddhølo, on the northeastern side of the island of Herdla, northwest of Bergen, is not shown on the map.

\section{Habitat categories}

Four habitat categories were distinguished in the two valleys; the rather similar II and III mainly for practical reasons. Slightly brackish-water localities constitute the fifth category. The localities fall into the following categories:

I. Four pools, one small lake and five tarns, all totally separate from the rivers and dispersed from the lowest to the highest parts of the valleys. Eksingedalen had eight of these localities, and Teigdalen just two small pools: locs.
1, 5, 7, 12, 13, 18a, 18b, 20, 31a, 31b. The $\mathrm{pH}$ was 5.0-5.5.

II. Mountain lakes; three in each of the valleys, situated at 760-969 m a.s.1.: locs. 19a, 19b, 19c, 21a, 21b, 21c, 22, 32, 33, 34a, 34b. The $\mathrm{pH}$ was 5.0-5.5.

III. River area in Eksingedalen; localities on, or in contact with, more or less lake-like, gently flowing parts on the lower stretch of the long river: locs. 2, 3, 4, 6a, 6b, 8, 9, 10, $11,14,15,16,17$. The $\mathrm{pH}$ was mostly 5.5-6.0; a few places 6.3-7.5.

IV. River area in Teigdalen; localities on, or more or less in contact with, lake-like, gently flowing parts on the lower stretch of this significantly shorter river, and by the shore where the river enters a lake, Evangervatn: locs. 23a, 23b, 23c, 24, 25, 26, 27, 28, 29a, 29b, 30a, 30b. The pH was 6.0-7.0.

V. The slightly brackish localities around Bergen: locs. 35, 36,37 , which were sampled throughout the year, and the small inlet, loc. 38 , where three samples were taken on a single day.

Table 1 lists the localities and briefly describes the habitats and physical conditions. 
Table I. Localities and habitat description.

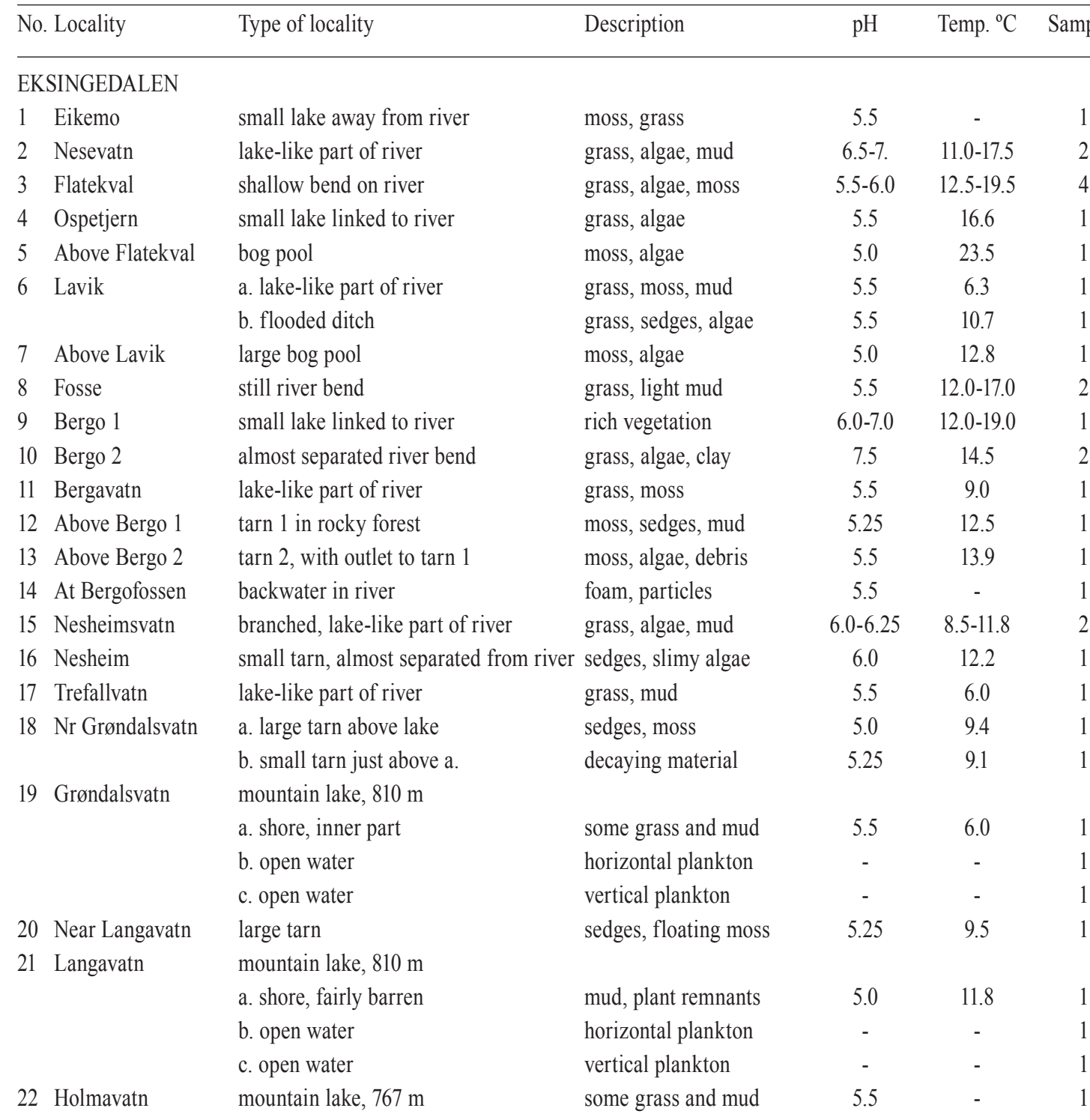

\section{TEIGDALEN}

23 Evangervatn

24 Farvodene

25 Mæstad

26 Mæstadvatn

27 Above Mæstadv.

28 Fastelandet

29 Sevaldstad

30 Langeland lake, $10 \mathrm{~m}$, river mouth

a. shore beside meadow

b. headland with rubbish

c. off a steep shore

extended part of the river

shore with farm rubbish

lake-like part of river

pool in flooded meadow

ditch into meadow

a. nearly separated bend

b. nearly separated ditch

a. ditch into meadow

b. small bend into meadow grass, mud

grass, algae

plankton

grass, mud

grass, moss, mud

grass, mud

grass, shore flowers

shore vegetation, mud

algae, mud, clay

rich shore vegetation

rich shore vegetation

rich shore vegetation
6.0

12.5

1

- $\quad-1$

- $\quad-\quad 2$

$\begin{array}{lll}6.0 & 8.2 & 1\end{array}$

$\begin{array}{lll}6.75 & 2.0 & 2\end{array}$

$6.0 \quad-\quad 1$

$\begin{array}{lll}6.25 & 11.0 & 1\end{array}$

$\begin{array}{lll}6.0 & 9.6 & 1\end{array}$

$\begin{array}{lll}6.0 & 9.0 & 1\end{array}$

$\begin{array}{lll}6.0 & 9.5 & 1\end{array}$

$\begin{array}{lll}7.0 & 11.0 & 1\end{array}$

$\begin{array}{lll}7.0 & - & 1\end{array}$ 
Table I. Continued.

\begin{tabular}{|c|c|c|c|c|c|}
\hline No. Locality & Type of locality & Description & $\mathrm{pH}$ & Temp. ${ }^{\circ} \mathrm{C}$ & Samples \\
\hline \multirow[t]{2}{*}{31 At Brekkhus } & a. pool in spruce forest & grass, decay & 5.5 & 10.1 & 1 \\
\hline & b. bog pool & moss, algae & 5.0 & - & 1 \\
\hline 32 Volavatn & mountain lake, $905 \mathrm{~m}$ & plankton at outlet & 5.5 & - & 1 \\
\hline 33 Borgavatn & mountain lake, $956 \mathrm{~m}$ & plankton at outlet & 5.5 & 4.8 & 1 \\
\hline \multirow[t]{3}{*}{34 Store Piksvatn } & mountain lake, $959 \mathrm{~m}$ & & & & \\
\hline & a. bay on north side & moss, mud & 5.5 & 6.0 & 1 \\
\hline & b. flowing water & plankton at outlet & - & - & 1 \\
\hline \multicolumn{6}{|c|}{ BRACKISH-WATER LOCALITIES AROUND BERGEN } \\
\hline 35 Nordåsvann & landlocked fjord, shore & green algae, mud & - & var. & some \\
\hline 36 Espegrend & brackish shore pools & marsh, stone, mud & var. & var. & many \\
\hline 37 Vågsbøpollen & landlocked fjord, shore & green algae, mud & - & var & some \\
\hline 38 Paddhølo & slightly brackish inlet & shore vegetation, mud & 7.0 & 21.0 & 3 \\
\hline
\end{tabular}

\section{RESULTS}

The 156 species (including a few subspecies) which have been identified are listed in a systematic order in Table 2, with the sampling localities and habitat categories, except for those from the freshwater localities that were visited later and which are only referred to areas.

Five species are only identified to the genus level, as they deviate markedly from all the species seen in the available literature. They are probably new species, but no type specimens have been deposited, and the information available about them is mostly too incomplete to name them as new species. Some species are rather similar to, but differ in some ways, from a certain species, and are denoted with cf. to that species.

"Die Rädertiere Mitteleuropas" (Voigt 1957) was initially used for the taxonomy and nomenclature. Later on, "Rotatoria" (Koste 1978), "Rotifera" 2: The Lecanidae (Segers 1995), "Rotifera" 3: The Notommatidae (Nogrady \& Pourriot 1995), "Rotifera" 4: The Proalidae (De Smet 1996), and "Rotifera" 5: The Dicranophoridae (De Smet 1997) have been used. The nomenclature and systematic order of the species mostly follow the "Termlist Rotifera" from the Nordic Code Centre (Pejler 1997). The recent "Annotated checklist of the rotifers" (Segers 2007) was also consulted. In addition, several other publications concerning rotifer taxonomy and descriptions of new species have been checked.

\section{Taxonomy and occurrence}

Notes or discussions are given concerning 46 species which are little known or which have a problematical taxonomy. Some measurements are given for all of these, and in most cases figures are included. Variations in size and shape are some- times commented on. Some relevant literature and material concerning the later, unpublished, investigations in Hordaland are referred to. In addition, information gained from the rotifer slide collections in the American Museum of Natural History (AMNH), New York, and in the Museum of Natural History in Toronto, Canada (derived from the rotifer specialist, the late G. M. Neal) has been given for some species. These collections were studied during a visit from April to June 1970.The following abbreviations of measurements are used: 1 . - total length of animal, 1.1. - length of lorica, b.l. - body length, b. - breadth of body, h. - height of body, t. - toe length, tr. - trophi length, f. - fulcrum length, r. - rami length, m. - manubrium length, u. uncus length, s.m. - supramanubrium length, sp. - spine length. The numbers measured are given in brackets.

\section{Microcodides chlaena (Gosse, 1886) tr. $22 \mu \mathrm{m}$}

Many specimens were found in a ditch connected to the river in Eksingedalen. This species was also found in two small lakes near Bergen.

\section{Microcodides sp.}

(Figure $2 \mathrm{~A}, \mathrm{C}$ )

\section{1. $235 \mu \mathrm{m}$, t. $22 \mu \mathrm{m}, \operatorname{tr} .22 \mu \mathrm{m} \times 36 \mu \mathrm{m}$ (1)}

Several specimens of this unknown Microcodides were found in the same ditch as mentioned above. Only one specimen was studied in detail and drawn, but apparently there was not much variation in size and shape within the population. This specimen differs from the other Microcodides figured in the literature. The toes are of equal size and shape and are placed beside each other, like in M. hertha (Wulfert 1961). They are, however, much more slender, and are slightly curved ventrally, tapering to acute tips. The rami have no alulae, but an oval structure from the beginning of the fulcrum, with a curved 

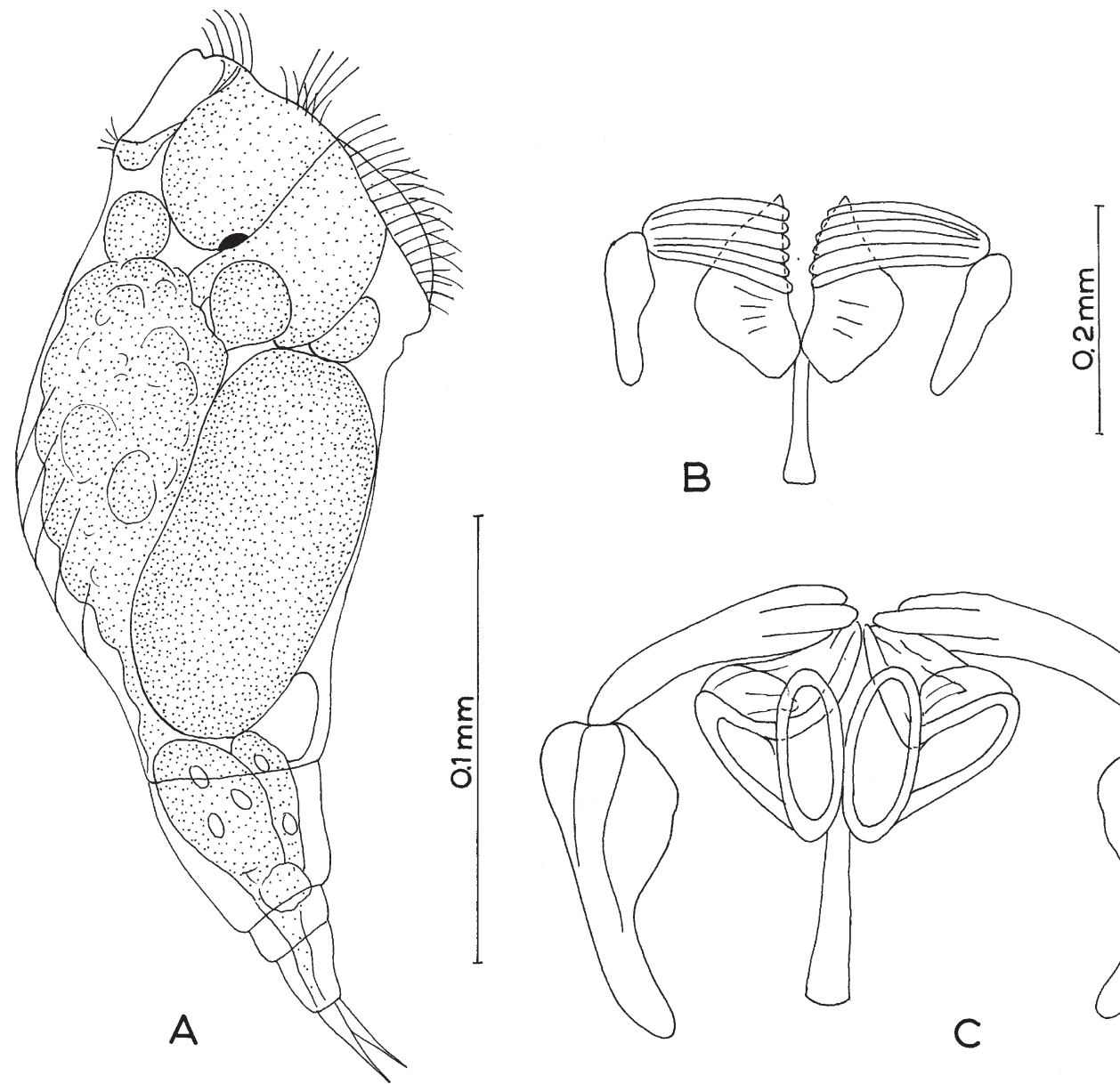

Figure 2. A and C: Microcodides sp., B: Microcodides chlaena, trophi.

"wing" laterally to it. Three teeth are seen on each uncus. This is probably a new species.

\section{Lecane cf. clara (Bryce, 1892)}

(Figure $3 \mathrm{~A}-\mathrm{C}$ )

b.1. $130 \mu \mathrm{m}, \mathrm{t} .40 \mu \mathrm{m}$, tr. $35 \mu \mathrm{m}(1)$

A single specimen was found in a large tarn in Eksingedalen. It was extended with a soft cuticle, so the shape of a contracted lorica was not seen. Nevertheless, it is quite characteristic in shape, especially the toes. It resembles Diglena beauchampi (von Hofsten 1923). Koste (1978) and Segers (1995) list that and also the similar Proales longidactyla (Edmondson 1948) as synonymous with $L$. clara. Their trophi differ from my specimen, however, in having a straight fulcrum. I later found more specimens, one somewhat contracted, in two tarns near Bergen. They also had the fulcrum end extended. A few specimens with the same size and shape were also found in two tarns on Hardangervidda. They have septa about 1/5 from the toe end. The trophi were not studied on them. Any other trophi figures of $L$. clara have not been found in the literature.

\section{Lindia sp.}

(Figure $3 \mathrm{D}, \mathrm{E}$ )

1. $320 \mu \mathrm{m}, \mathrm{t} .18 \mu \mathrm{m}, \operatorname{tr} .33 \mu \mathrm{m} \times 36 \mu \mathrm{m}$ (1)

A single specimen was found on the shore of Evangervatn, near the river mouth. It could not be identified as any of the species figured in the available literature. The trophi are fairly large and complicated. The fulcrum and rami, and mostly also the manubria, are similar to those of $L$. pallida (Harring \& Myers 1921), but larger. Two extra pieces partly cover the anterior parts of the rami. The epipharynx pieces have three or four large teeth in the front.

\section{Lindia pallida Harring \& Myers, 1921 \\ (Figure 3 F) \\ tr. $25 \mu \mathrm{m} \times 32 \mu \mathrm{m}(1)$}

The species was found in two bog pools. Only the trophi were studied in detail. They correspond fairly well to the figure given by Harring \& Myers (1921), but are a little larger. Each uncus has four or five teeth on its widened end, and the epipharynx pieces have two teeth. 

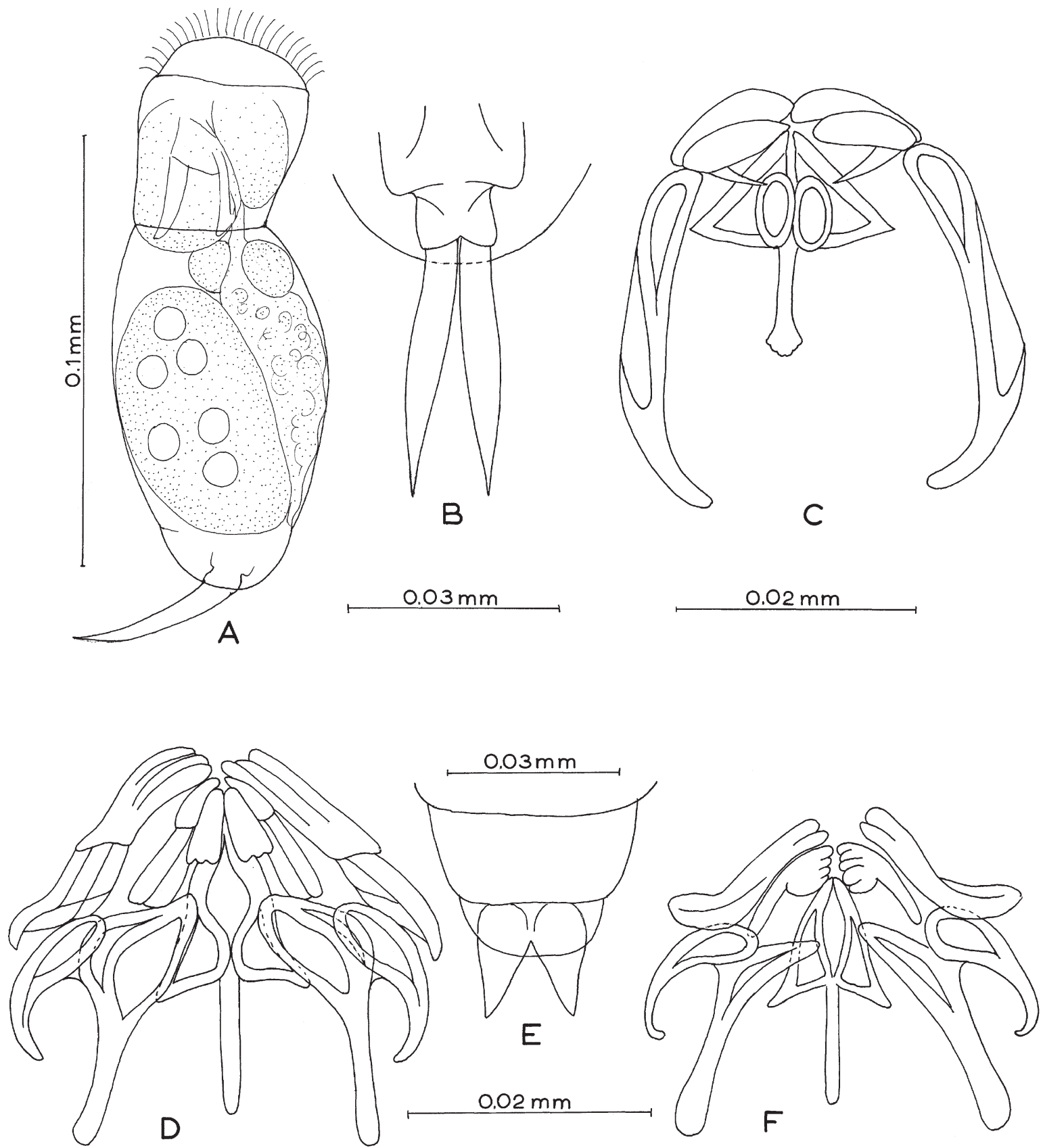

Figure 3. A-C: Lecane cf. clara, D and E: Lindia sp., trophi and foot with toes. F: Lindia pallida, trophi.

Cephalodella apocolea Myers, 1924

(Figure 4 A-C)

1. $146 \mu \mathrm{m}$, t. $42 \mu \mathrm{m}$, tr. $28 \mu \mathrm{m}(1)$

A single specimen was found in Langavatn, a large tarn in Eksingedalen, and another in a small bog pool in Teigdalen. Only one specimen was studied in detail. The shape of the toes is characteristic. The outlines of trophi in lateral position mostly correspond to the three figures seen in the literature (Hauer 1935; Wulfert 1940; Eriksen 1969).
Cephalodella auriculata (Müller, 1873)

(Figure 4 D-F)

1. 111-121 $\mu \mathrm{m}$, t. $25-26 \mu \mathrm{m}$, tr. $32-36 \mu \mathrm{m}(2)$

The species was found in small numbers at eight localities in Eksingedalen. It is shorter than is mostly recorded in the literature. It was even shorter $(1.87-114 \mu \mathrm{m})$ in a tarn near Bergen, where it was frequent. The smallest were possibly young ones. 

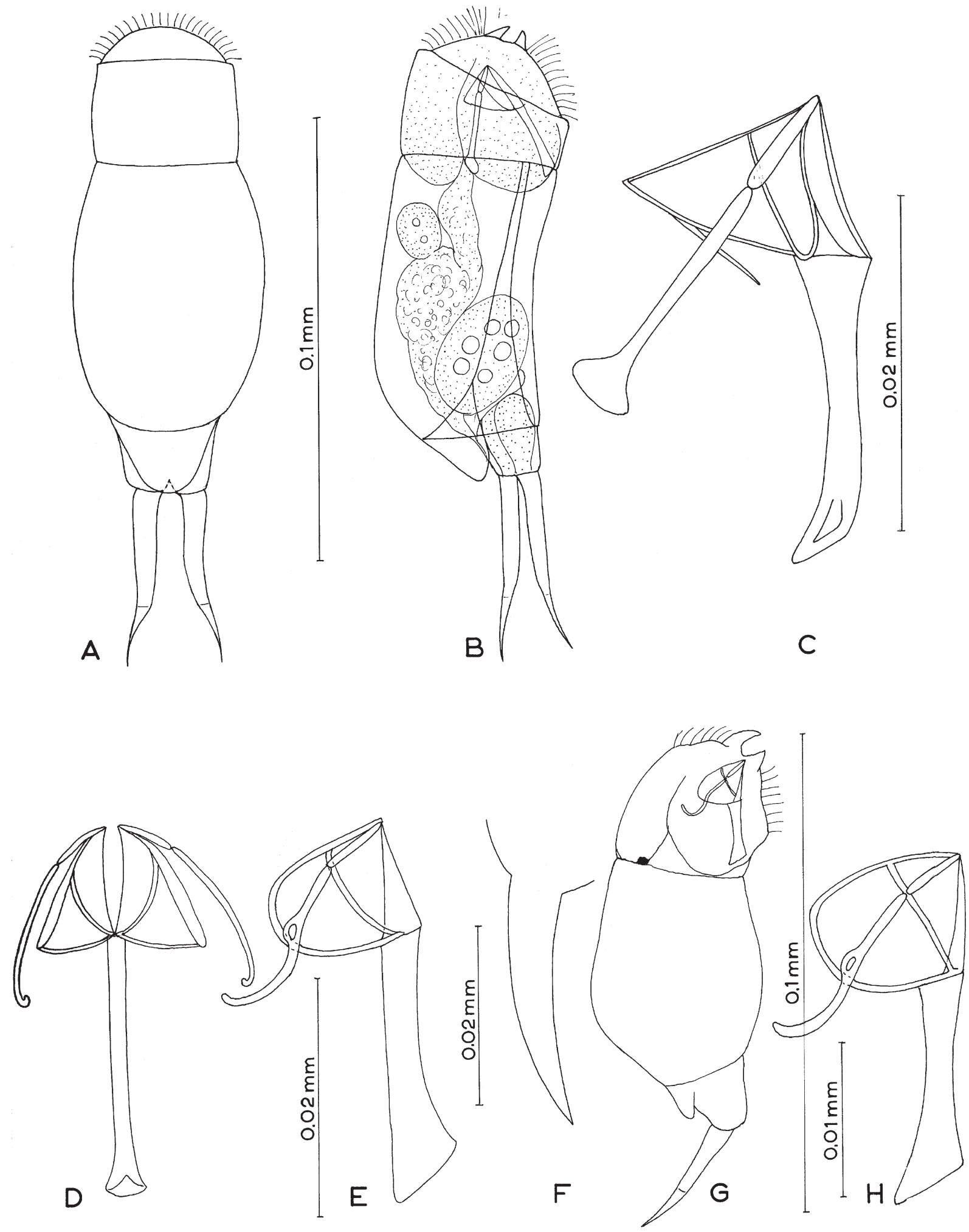

Figure 4. A-C: Cephalodella apocolea, D-F: Cephalodella auriculata, trophi and toe. G and H: Cephalodella derbyi. 


\section{Cephalodella cf. delicata Wulfert, 1937 \\ (Figure 5)}

1. $112-122 \mu \mathrm{m}$, t. $18-22 \mu \mathrm{m}$ (2), tr. $22-25 \mu \mathrm{m}$ (3)

The species was found in small numbers at seven localities. It corresponds quite well in size and shape to the species described by Wulfert (1937), but the trophi differ a little. On the present specimens, the alulae on the rami point a little more to the sides, and the manubria are somewhat shorter and more like those of the trophi of type A. Similar specimens with this trophi form, as well as some with trophi shaped more or less like those figured by Wulfert (1937), were found later in a tarn and two lakes near Bergen; hence, probably all are variations of $C$. delicata.

\section{Cephalodella cf. dentata Wulfert, 1937} (Figure 6 F-I)

1. 140-150 $\mu \mathrm{m}$, t. $25-29 \mu \mathrm{m}$, tr. $21-26 \mu \mathrm{m}, \mathrm{m} .12 .2-15.1 \mu \mathrm{m}$ and 16.5-17.6 $\mu \mathrm{m}$ (7). Smaller specimen: $1.110 \mu \mathrm{m}$, t. $19 \mu \mathrm{m}$, tr. 22 $\mu \mathrm{m}, \mathrm{m} .14 .1 \mu \mathrm{m}$ and $16.6 \mu \mathrm{m}(1)$

The larger specimens were found at seven localities. The trophi correspond to those figured by Wulfert (1937), with the marked teeth on the rami and the somewhat crutched manubria of different length. The present specimens are, however, slightly shorter than those described by Wulfert. The toes in particular are shorter, and also more evenly tapering, and septa are mostly seen about $1 / 3$ from the tips.

The smaller specimen was found at another locality. It has narrower rami with less marked teeth, and no septa on the toes. The manubria are slightly asymmetrical. It also resembles $C$. rotunda bryophila (Pawlowski 1938), but the toes are not ventrally bent. Possibly both are variations of $C$. dentata.

\section{Cephalodella derbyi (Dixon-Nuttall, 1903) (Figure 4 $\mathrm{G}, \mathrm{H})$ \\ 1. $112 \mu \mathrm{m}$, t. $28 \mu \mathrm{m}, \operatorname{tr} .22 \mu \mathrm{m}(1)$}

A single specimen was found in a small lake near the river mouth in Eksingedalen. The size and shape of the body and toes correspond fairly well to the original species description, but the toes have septa about 2/5 from the ends. Septa are also shown by Wulfert (1951), but his specimens were larger than the present one. The trophi are of type A. No other trophi figure is given in the available literature.

\section{Cephalodella forficata (Ehrenberg, 1832) (Figure 7) \\ 1. $200-220 \mu \mathrm{m}$, t. $46-54 \mu \mathrm{m}$, tr. $32-40 \mu \mathrm{m}$ (2)}

The species was found in small numbers at six localities. The manubria are a little asymmetrical, with lamellae and crutched ends, the fulcrum has an extended end and the rami have many
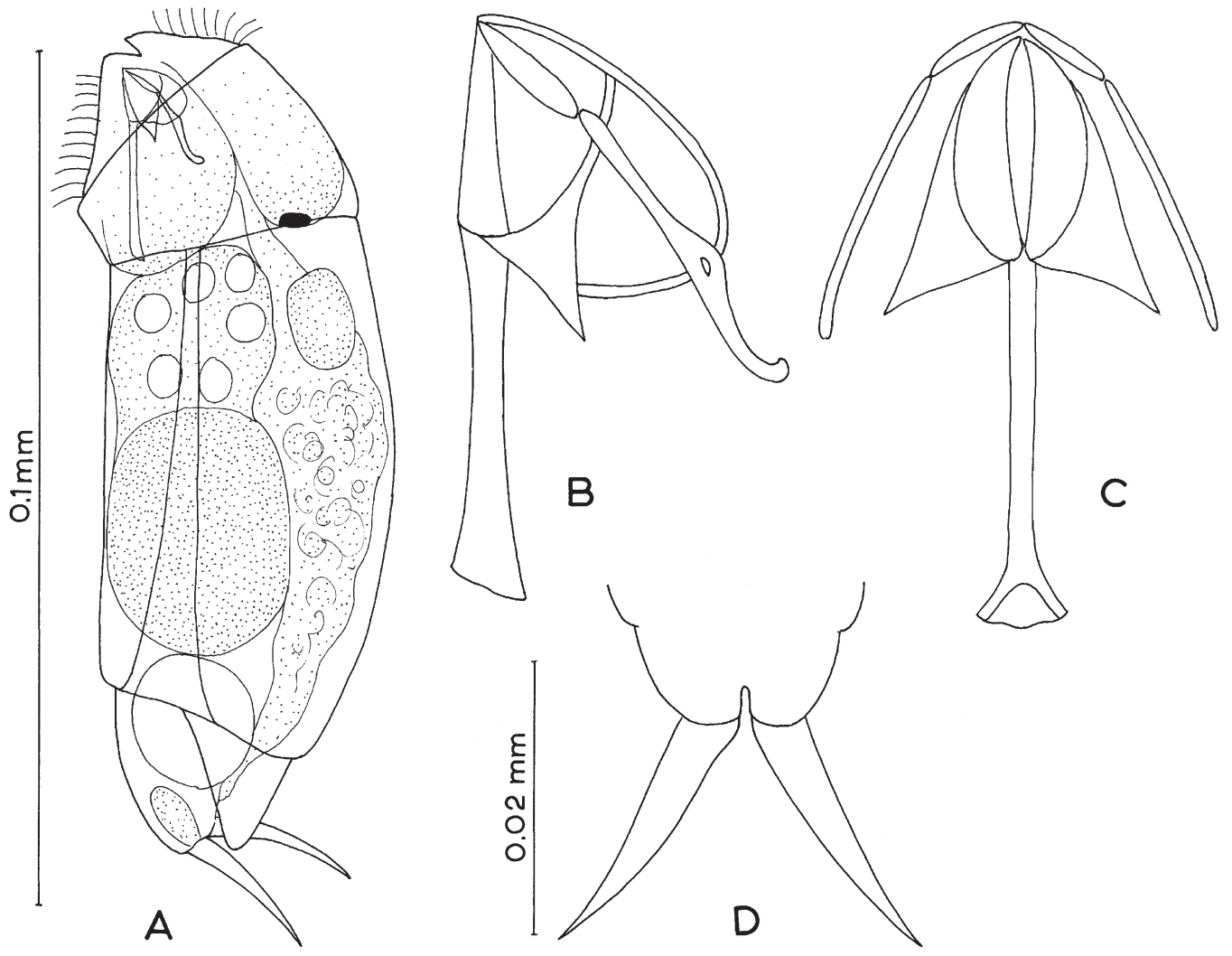

Figure 5. A-C: Cephalodella $\mathrm{cf}$. delicata. 

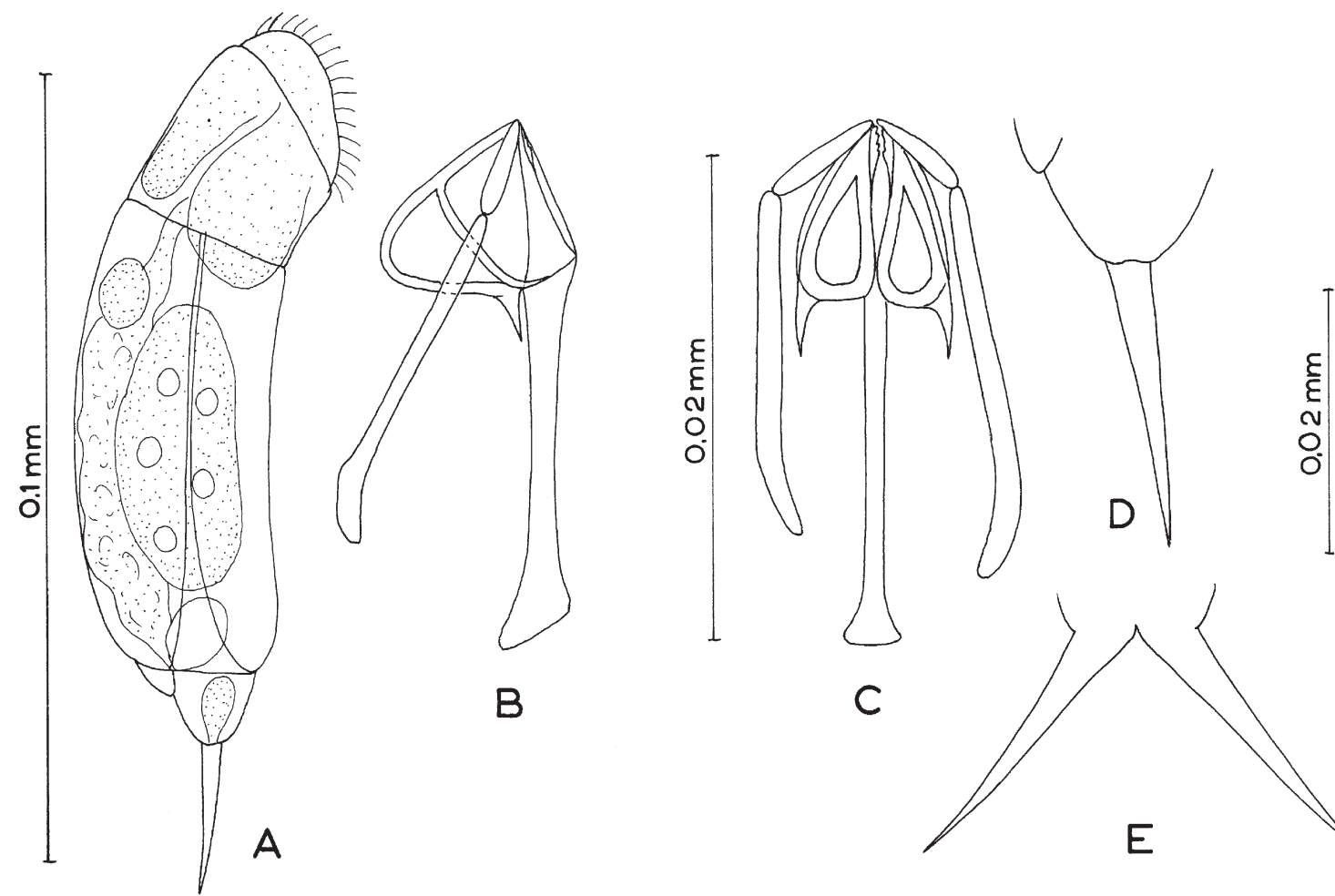

B
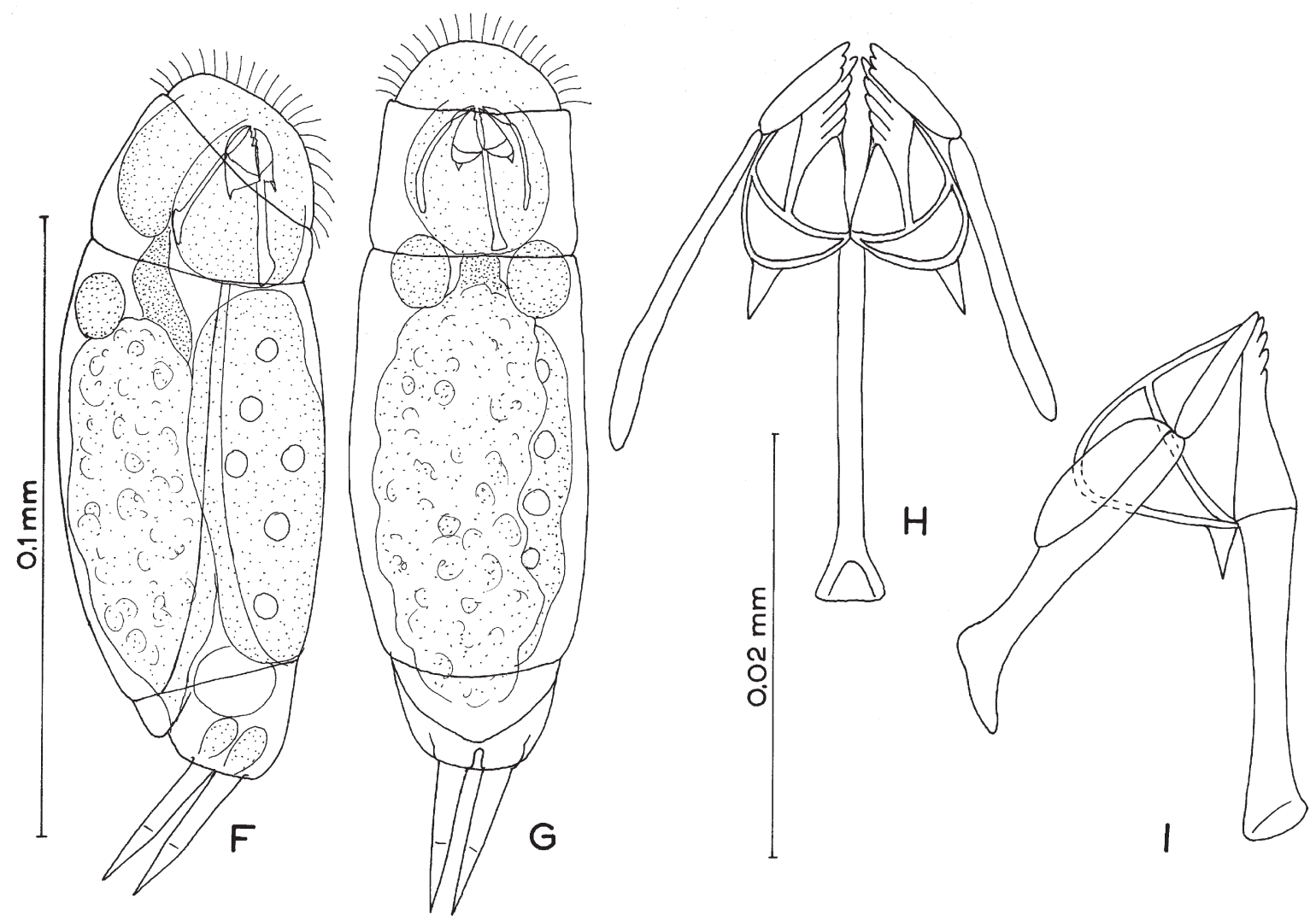

Figure 6. Cephalodella $\mathrm{cf}$. dentata. A-E: Small specimens. F-I: Large specimens. 
marked teeth. The toes are characteristic.

\section{Cephalodella gibba (Ehrenberg, 1838)}

(Figures 8 and 9)

Normal form (Fig. 8 A-C): 1. 242-245 $\mu \mathrm{m}$ (2), t. 76-92 $\mu \mathrm{m}$ (6), tr. $55 \mu \mathrm{m}$ (1). Giant form (Fig. $8 \mathrm{D}-\mathrm{G}$ ): $1.350 \mu \mathrm{m}$, b.l. $214 \mu \mathrm{m}$, t. $137 \mu \mathrm{m}$, tr. $75 \mu \mathrm{m}$ (1). Small form (Fig. 9): 1. 228-230 $\mu \mathrm{m}$ (3), t. $60-62 \mu \mathrm{m}(4), \operatorname{tr} .44-47 \mu \mathrm{m}(5)$

The normal form occurred at several localities in the valleys, and was also common in several lakes and tarns around Bergen and on Hardangervidda. The giant form occurred only as a single specimen in a tarn in Eksingedalen. The small form was found in a few shore pools at Espegrend and in Paddhølo.

The giant form has very long and relatively much more slender toes than the normal one. They are a little constricted at the proximal end, then somewhat swollen before tapering, and they end in acute points that are markedly set off. The trophi are also much larger, but do not seem to differ markedly from the normal form. Slide no. 838 in AMNH, marked C. gibba, contains three trophi of the same size $(76-77 \mu \mathrm{m})$, and slide no. 434 , one $(76 \mu \mathrm{m})$. Finally, slide no. 199 after Neal shows trophi of $80 \mu \mathrm{m}$. The giant form recorded by Wulfert (1937), with $1.450 \mu \mathrm{m}$, t.

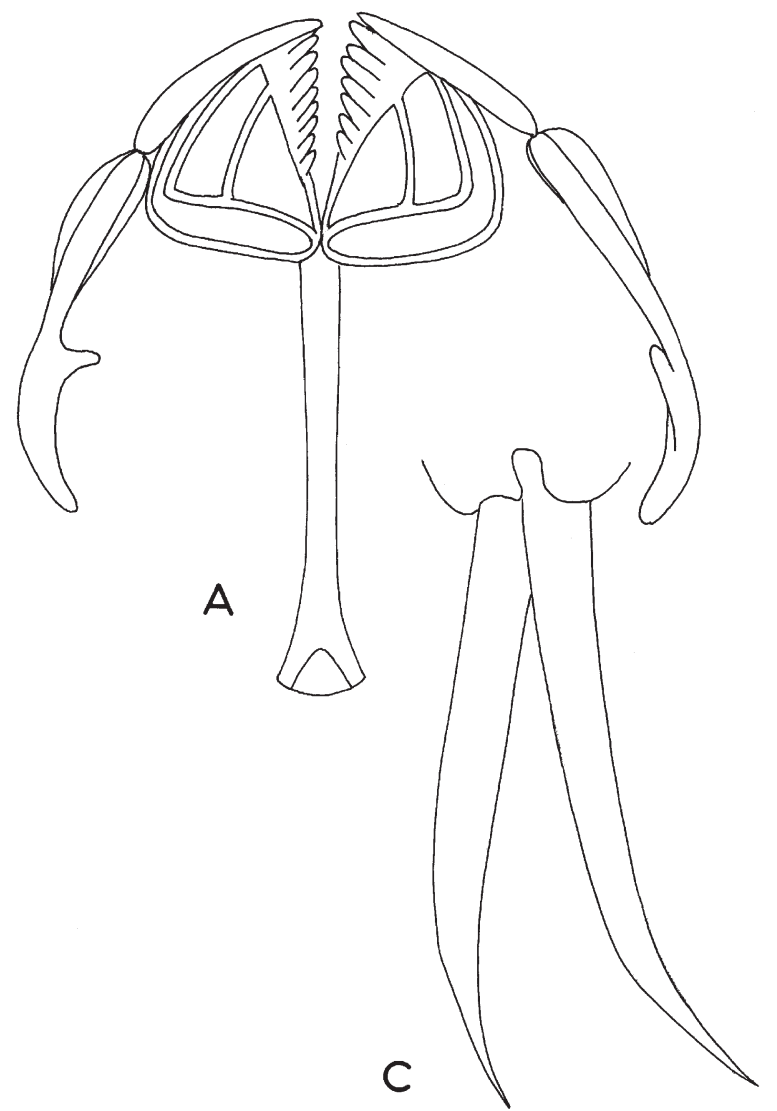

$150 \mu \mathrm{m}$ and tr. $85-90 \mu \mathrm{m}$, was not figured.

The small form was found only in the slightly brackish localities, and it corresponds to that described as subspecies microdactyla by Koch-Althaus (1963). It had, however, no marked teeth on the rami and apparently no lamellae on the manubria. The "rods" across the rami could sometimes be seen. In Finland, this form was common both in brackish and freshwater localities (Eriksen 1969; Bjørklund 1972). De Smet (2001) studied the trophi of this form and the normal one and saw no real differences. As there are transitional lengths of body and toes, he rejected the subspecies status.

I have measured the toe length of 84 C. gibba-like specimens, and the total length of 18 , not contracted, specimens from Hordaland and southern Finland. Almost all toe lengths between 59 and $108 \mu \mathrm{m}$ are represented, but with a marked peak at 59-64 $\mu \mathrm{m}$ (mostly the microdactyla form). After that size group, the lengths are quite evenly distributed up to $108 \mu \mathrm{m}$, before the single giant toes of $137 \mu \mathrm{m}$. The available literature records all toe lengths between 55 and $108 \mu \mathrm{m}$, with a small peak between 55 and $70 \mu \mathrm{m}$. Slide 62 from AMNH shows five specimens with toe lengths of $110-119 \mu \mathrm{m}$, after which there is

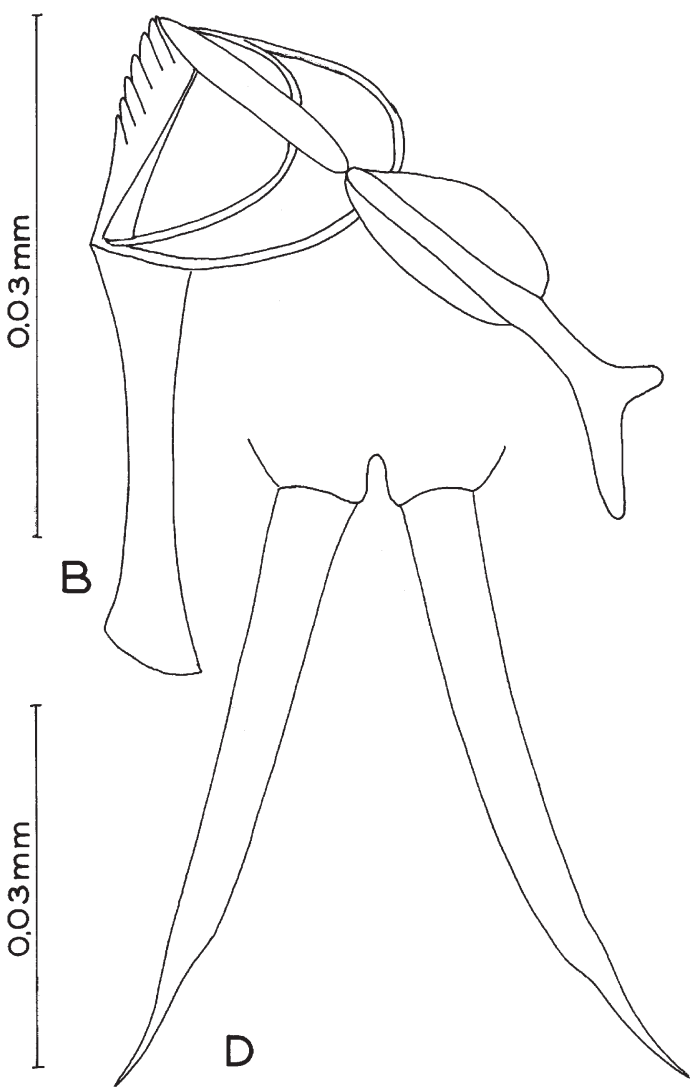

Figure 7. A-D: Cephalodella forficata, trophi and toes seen from the left and dorsally. 

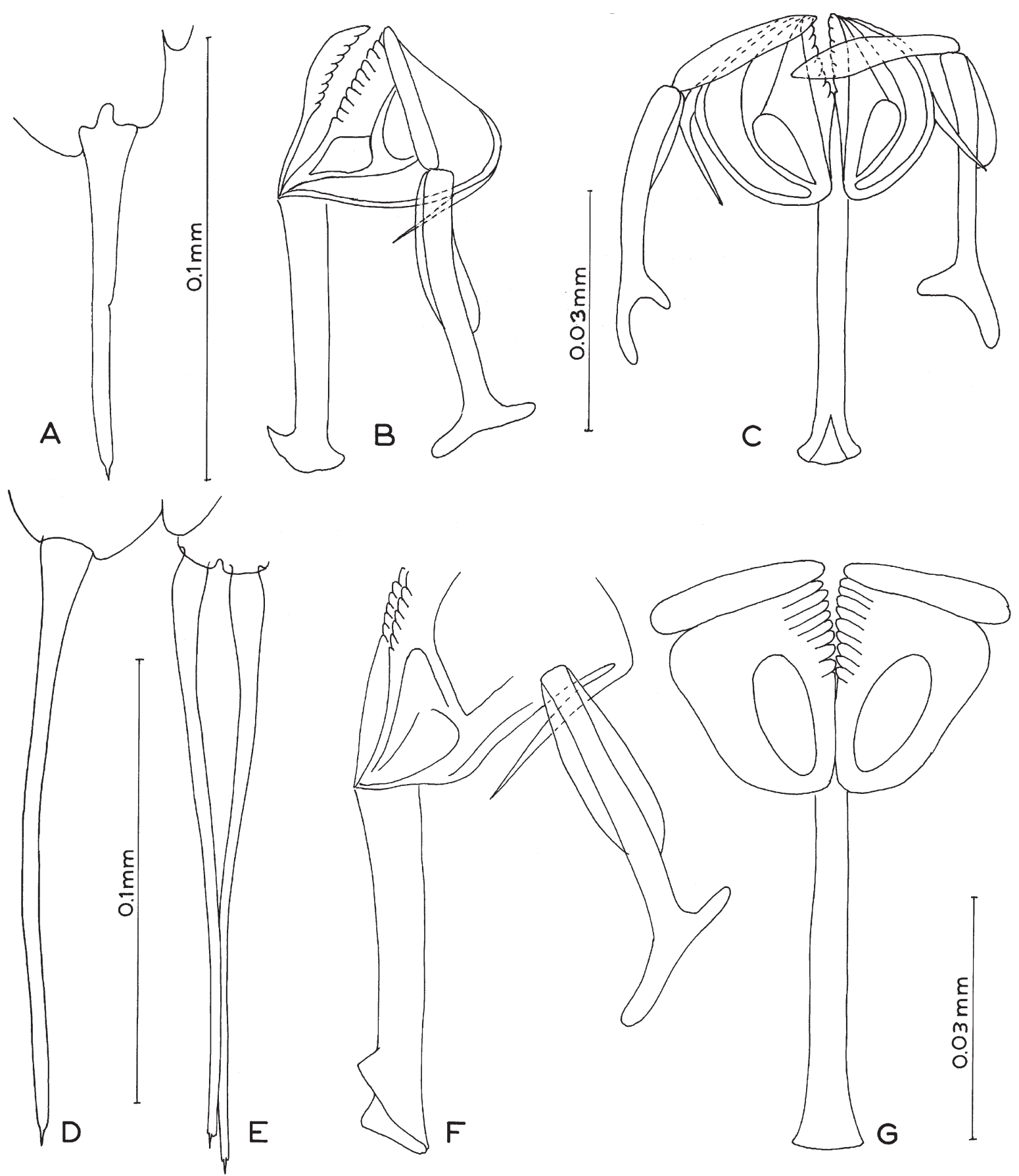

Figure 8. A-G: Cephalodella gibba, toes and trophi. A-C: Normal form. D-G: Giant form.

a gap to Wulfert's (1937) toe record of $150 \mu \mathrm{m}$. I cannot find any connection between the length of the body and the toes, as long specimens could have short toes and vice versa. All these measurements support the conclusion that $C$. gibba is a single, highly variable species, with a wide distribution. There is, however, still some uncertainty about the rare giant forms.
Cephalodella glandulosa Koch-Althaus, 1962

(Figure 10)

t. $27 \mu \mathrm{m}$, tr. $28 \mu \mathrm{m}(1)$

A single specimen was found in a mountain lake. Only the toes and trophi could be studied in detail, but they show great resemblance in size and shape to those of $C$. glandulosa described from northern Germany (Koch-Althaus 1962). That record, and 


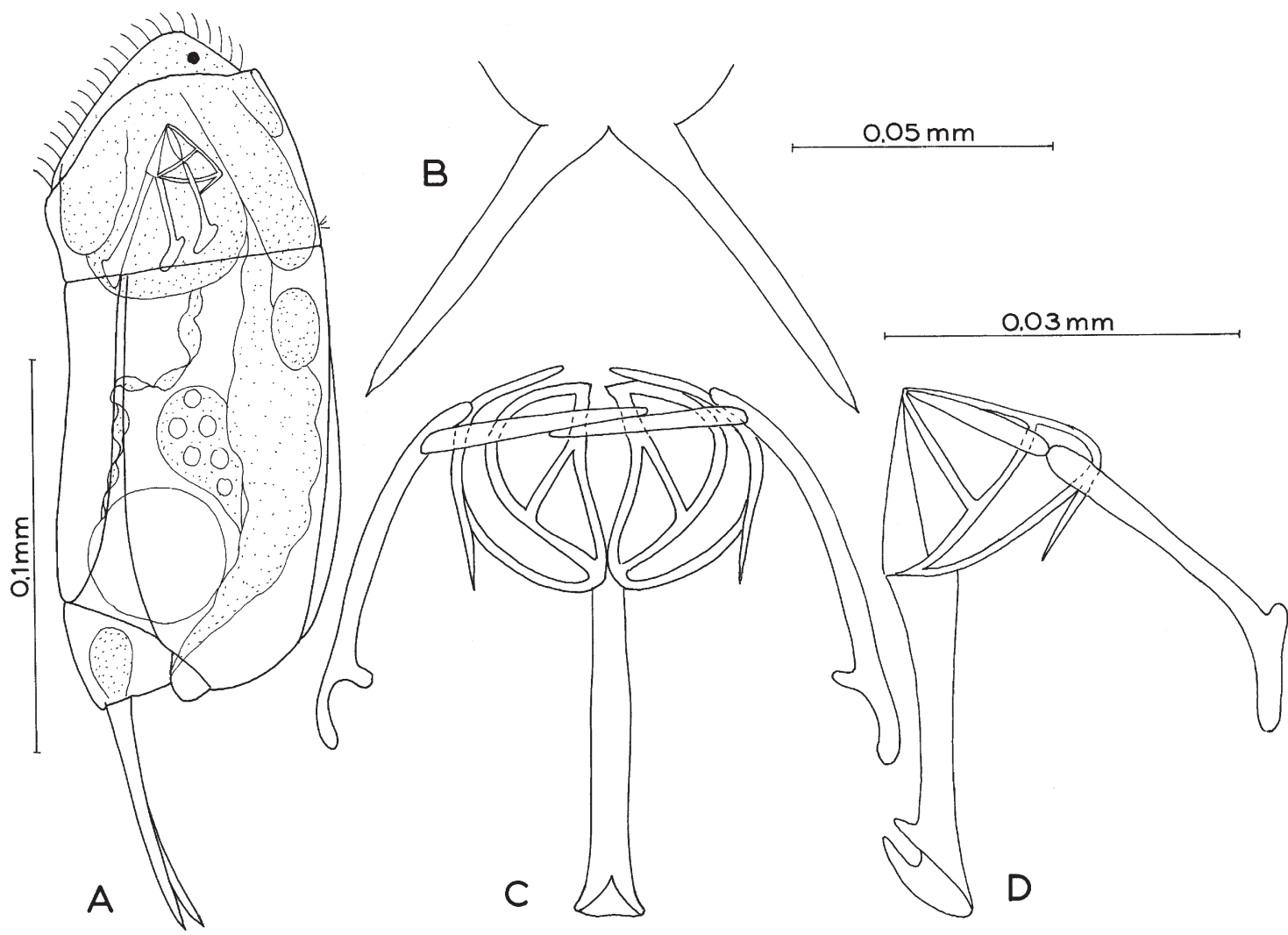

Figure 9. A-D: Cephalodella gibba, small form.

one from Barentsøya, Svalbard (De Smet 1993), seem to be the only ones hitherto.

\section{Cephalodella harringi Smirnov, 1927} (Figure $11 \mathrm{~A}-\mathrm{D}$ )

1. $102 \mu \mathrm{m}$, t. $15 \mu \mathrm{m}$, tr. $27 \mu \mathrm{m}(1)$

A single specimen was found in a lake-like part of the river in Eksingedalen. It resembles the species described by Smirnov (1927) from Russia, both in size and shape, but has slightly more slender toes. I also found similar specimens in a tarn and a small lake near Bergen, with the measurements 1. 85-97 $\mu \mathrm{m}$, t. $12-15 \mu \mathrm{m}, \operatorname{tr} .22-28 \mu \mathrm{m}$ (8). Their toes varied in thickness at the base, being more like the species figured by Smirnov (1927).

Koste (1978) mentioned it as a possible synonym of $C$. crassipes (Lord, 1903), and Nogrady \& Pourriot (1995) listed it as synonymous to that. However, $C$. crassipes is much larger and has quite different trophi and toes. Jersabek (2002) considered it to be a species inquirenda. Finally, Segers (2007) listed it as a separate species. My records support him. C. harringi does not seem to be recorded earlier by other authorities than Smirnov.

\section{Cephalodella intuta Myers, 1924 (Figure $11 \mathrm{E}-\mathrm{G}$ )}

1. $140-217 \mu \mathrm{m}$, t. $43-54 \mu \mathrm{m}, \operatorname{tr} .27-36 \mu \mathrm{m}$ (5)

The typical species with marked teeth and small alulae on the rami, and mostly lamellae seen on the manubria, was found in small numbers at four localities in the valleys. The specimens found in pools at Espegrend (shown in the figure) have no teeth or alulae on the rami; also seen in $C$. intuta jamaicaensis (Koste et al. 1993). No lamellae were seen on the manubria in the present specimens, however, which are also larger and have smaller toes (shown in the figure).

\section{Cephalodella megalocephala (Glascott, 1893) (Figure 12 A-E)}

1. $150-166 \mu \mathrm{m}$, t. $30-35 \mu \mathrm{m}$, tr. $38 \mu \mathrm{m}$ (2)

A single specimen was found in Eksingedalen, and a few in the weakly brackish Paddhølo. The body was small, partly due to some degree of contraction. The toes had no visible joints. The same small form without toe joints was also found in a small lake near Bergen. 


\section{Cephalodella nana Myers, 1924}

(Figure 12 F-I)

1. $110 \mu \mathrm{m}$, t. $30 \mu \mathrm{m}$, tr. $32 \mu \mathrm{m}$ (1)

A single specimen was found in Eksingedalen. It is small, with a relatively large head and long, ventrally curved toes, like those seen on C. cuneata (Harring \& Myers 1924), a synonym of $C$. nana. The same species was also found in a small lake near Bergen.

\section{Cephalodella pachydactyla Wulfert, 1937 (Figure 13) \\ 1. $118-137 \mu \mathrm{m}$, t. $26-34 \mu \mathrm{m}$, tr. $21-23 \mu \mathrm{m}(8)$}

The species was found in shore pools at Espegrend, in salinities up to about $2 \%$. It was recorded throughout the summer, but never in great abundance. One specimen was also found in the river in Teigdalen. My specimens correspond with the species described by Wulfert (1937). Two separate eye spots were seen in the dorso-ventral position.

\section{Cephalodella sterea (Gosse, 1889)}

(Figure $14 \mathrm{~A}-\mathrm{D}$ )

1. $116 \mu \mathrm{m}, \mathrm{t} .28 \mu \mathrm{m}, \operatorname{tr} .27 \mu \mathrm{m}(1)$

A single, small specimen was found in the river in Teigdalen. It corresponds fairly well to the form described as C.sterea $\mathrm{f}$. minor by Donner (1950). The trophi have a few teeth on both rami, as also recorded by Dumont \& Coussement (1976). No marked alulae were seen on the rami.

\section{Cephalodella tantilloides Hauer, 1935}

(Figure $14 \mathrm{E}-\mathrm{G}$ )

1. $136-140 \mu \mathrm{m}$, b.1. $85-100 \mu \mathrm{m}$, t. $44-50 \mu \mathrm{m}$, tr. $26-32 \mu \mathrm{m}$ (4) The species was found at several localities, all but one in
Eksingedalen. The specimens correspond fairly well with the species described by Hauer (1935). This species was also found in a small lake and two tarns near Bergen.

\section{Cephalodella theodora Koch-Althaus, 1961 \\ (Figure $15 \mathrm{~A}-\mathrm{F}$ ) \\ 1. $170-180 \mu \mathrm{m}$, t. $27-30 \mu \mathrm{m}$, tr. $35-38 \mu \mathrm{m}$ (3)}

The species was found at four localities in, or in connection with, the rivers in both valleys. It corresponds quite well in both size and shape with the species described by Koch-Althaus (1961). It has two separate cerebral eye spots. The gastric glands are rounded and not in connection with the ganglion. The rami have each 10 or 11 blunt teeth along the anterior $3 / 5$ of their median parts, and the unci have two teeth each. The manubria have lamellae, but no feather-like structures. The species has only been recorded from Germany and Canada (Nogrady 1988).

\section{Cephalodella ventripes (Dixon-Nuttall, 1901)}

(Figure 15 G-J)

1. $110-128 \mu \mathrm{m}$, b.l. $84-120 \mu \mathrm{m}$, t. $26-29 \mu \mathrm{m}$, tr. 30-38 $\mu \mathrm{m}$, f. 16$21 \mu \mathrm{m}, \mathrm{r} .12-15 \mu \mathrm{m}(8)$

Male: $100-120 \mu \mathrm{m}$, t. $20-22 \mu \mathrm{m}$ (2)

This species was very common and sometimes abundant, especially in Eksingedalen, where males were seen at three localities.

\section{Cephalodella sp.}

(Figure 16)

1. $192 \mu \mathrm{m}$, b.l. $124 \mu \mathrm{m}$, t. $78 \mu \mathrm{m}$, tr. $28 \mu \mathrm{m}$ (1)

A single specimen of an unknown Cephalodella was found in a sample from a shallow, flooded, grassy bend on the river in Eksingedalen. Another sample was taken three days later at the

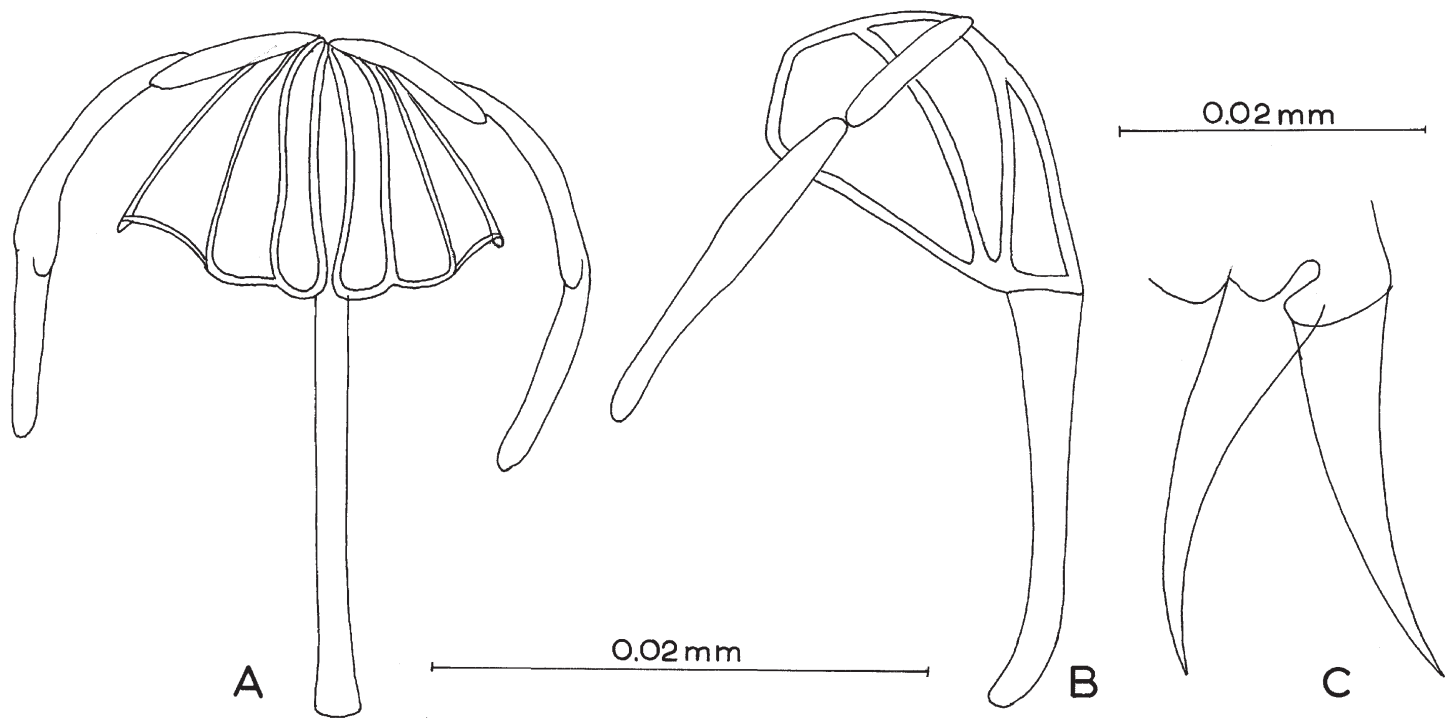

Figure 10. A-C: Cephalodella glandulosa, trophi and toes. 
Fauna norvegica 29: 1I-54. 2009
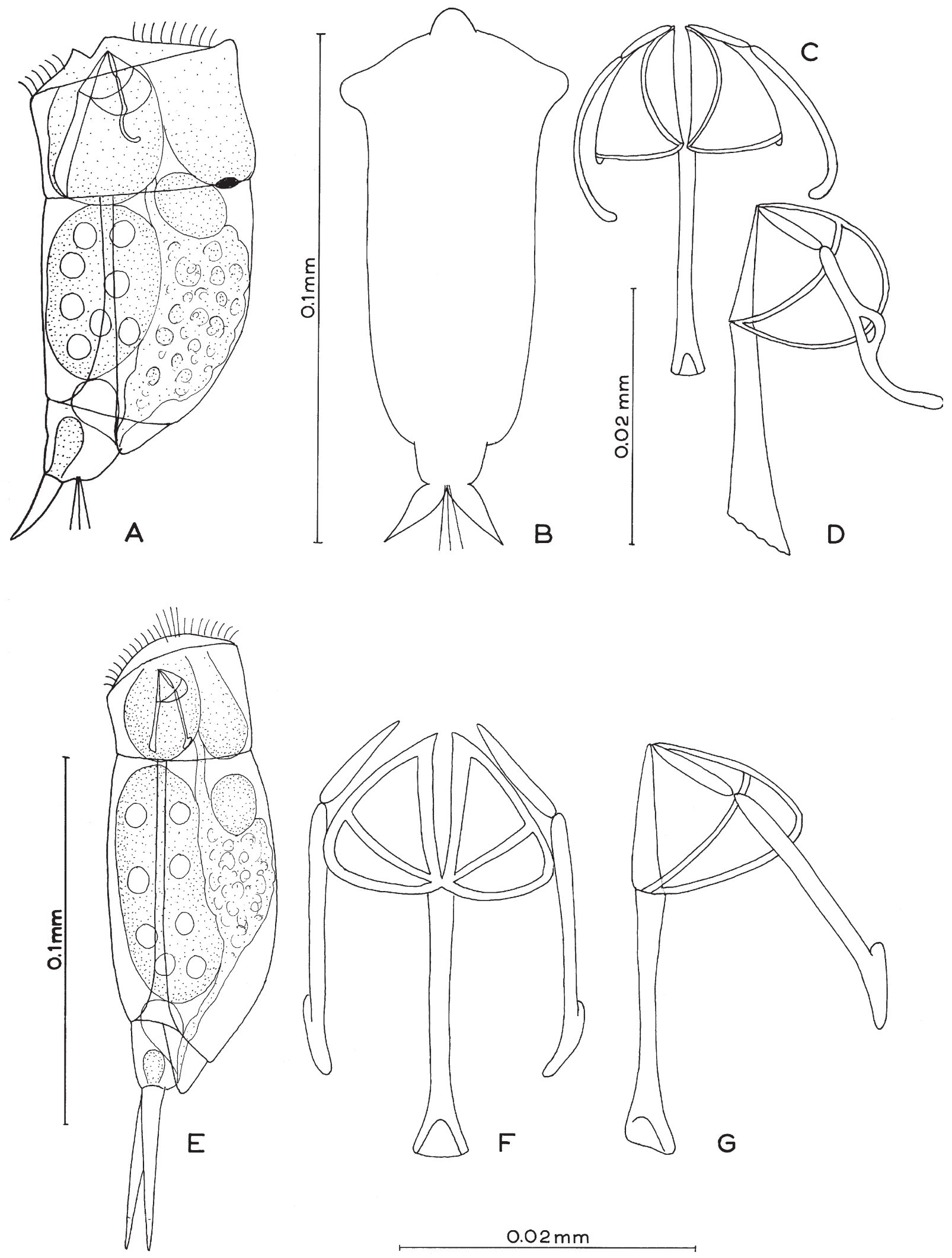

Figure II. A-D: Cephalodella harringi. E-G: Cephalodella intuta.

25 
same locality, to seek more specimens. Unfortunately, heavy rain had fallen in the meantime, flooding the bend even more, and the original sampling site was not reached. Only five other species were found in the nearest reachable site.

The specimen is quite characteristic with its plump body, large head and long, slightly ventrally curved toes, situated rather ventrally. Seen from the ventral side, the toes are bent to each side. It has a broadly extended cerebral eye spot, and trophi of type A. The inner organs could not be studied in detail. The cuticle looks quite soft, and it may be a young individual. It probably represents a new species.
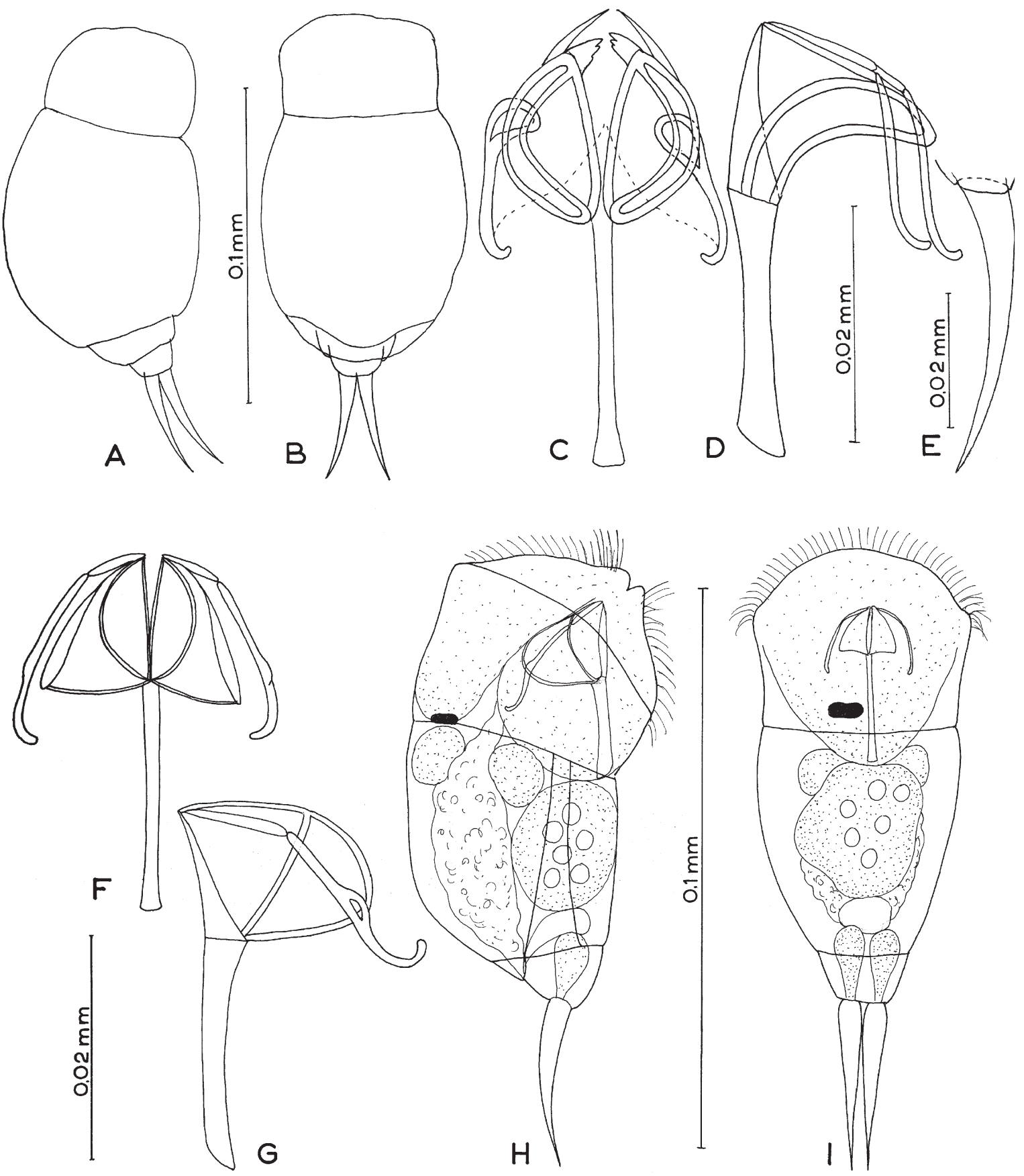

Figure I2. A-E: Cephalodella megalocephala. F-I: Cephalodella nana. 


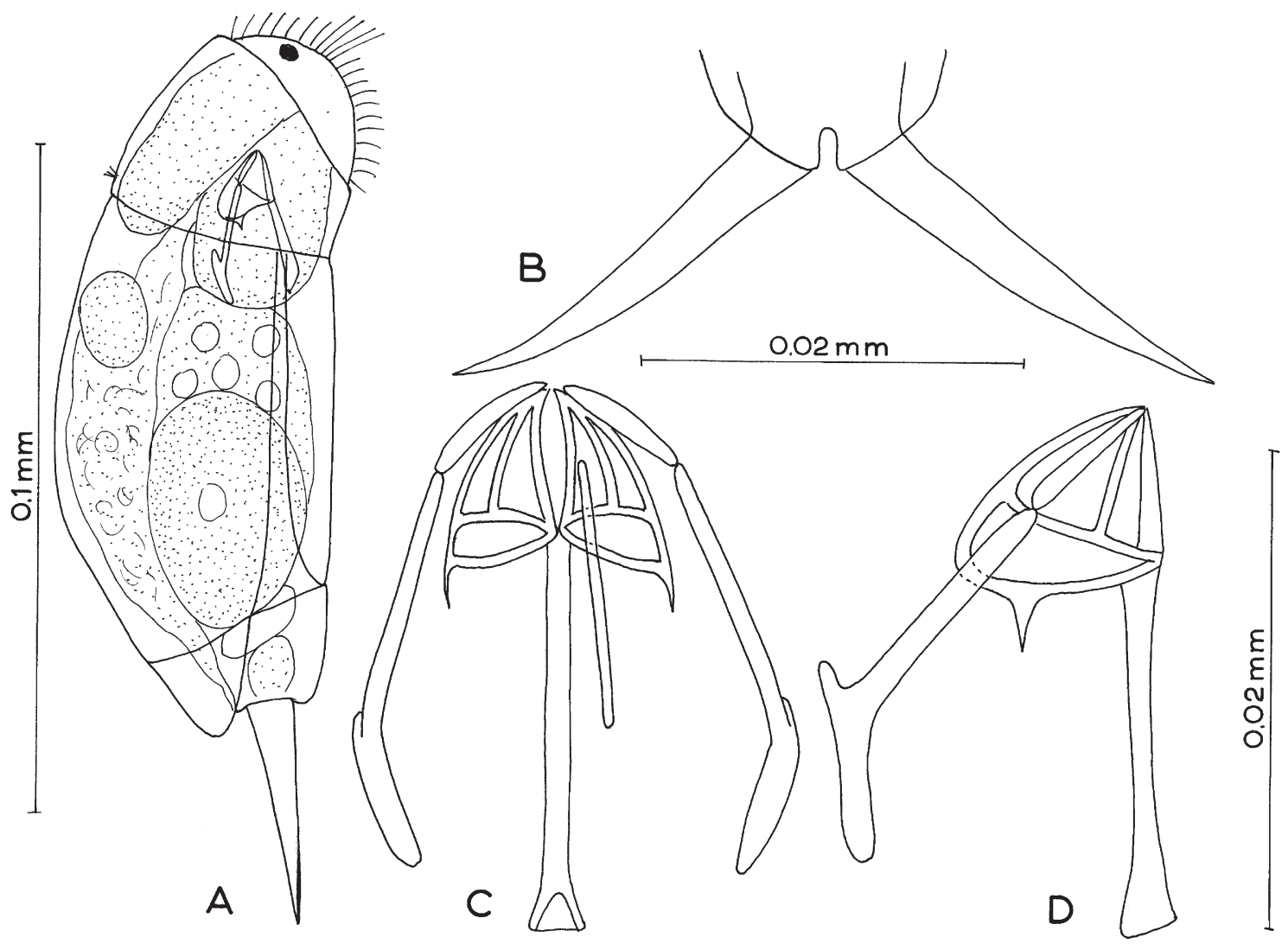

Figure 13. A-D: Cephalodella pachydactyla.

\section{Momommata $\mathrm{cf}$. actices Myers, 1930}

(Figure $17 \mathrm{~A}, \mathrm{~B}$ )

b.1. $134 \mu \mathrm{m}$, t. $126 \mu \mathrm{m}$ and $104 \mu \mathrm{m}$, tr. $25 \mu \mathrm{m}$, egg $44 \times 35 \mu \mathrm{m}$

A single specimen was found in the river in Eksingedalen. It is markedly smaller than the species described by Myers (1930), and also the specimen figured by Wulfert (1960). Especially the toes are much smaller. The trophi are of the same size, however, and also correspond fairly well in shape. A similar specimen found in a small lake near Bergen also had short toes $(130 \mu \mathrm{m}$ and $90 \mu \mathrm{m})$.

\section{Monommata cf. phoxa Myers, 1930}

(Figure $17 \mathrm{C}-\mathrm{G}$ )

b.l. (somewhat contracted) $140 \mu \mathrm{m}$, t. $246 \mu \mathrm{m}$ and $167 \mu \mathrm{m}$, tr. $23 \mu \mathrm{m}$, egg $54 \times 35 \mu \mathrm{m}(1)$

A single specimen was found in a small lake far down in Eksingedalen. The trophi are rather similar to the species described by Myers (1930). The body length is difficult to compare, but the toes are much longer than those figured by him. A similar specimen with markedly smaller toes was found in a small lake near Bergen.

\section{Resticula nyssa Harring \& Myers, 1924} (Figure 18)

1. (somewhat contracted) $330 \mu \mathrm{m}$, t. $16-18 \mu \mathrm{m}$, tr. $48-52 \mu \mathrm{m}$ (2) One specimen (Fig. $18 \mathrm{D}-\mathrm{G}$ ) was found in the river in Eksingedalen and another (Figure $18 \mathrm{~A}-\mathrm{C}$ ) in the river in Teigdalen. They differ a little in the shape of the trophi, but both have very similar trophi to those in figures found in the literature concerning $R$. nyssa, which also vary slightly. The toes, with their swollen basal parts, are characteristic.

\section{Notommata lenis Harring \& Myers, 1922}

1. 240-260 $\mu \mathrm{m}$ (3), t. $12-15 \mu \mathrm{m}$ (4), tr. 33-37 $\mu \mathrm{m}$ (4), egg 100x72 $\mu \mathrm{m}$, spikes $10 \mu \mathrm{m}$

The species was found at five localities in the river in Eksingedalen, and was quite numerous at one locality. Many individuals were carrying spiky resting eggs, and loose eggs were also found. The specimens were fairly similar to the species figured by Nogrady \& Pourriot (1995), after Harring $\&$ Myers (1922), but with no measurements. The species only seems to have been recorded from the USA and France. 


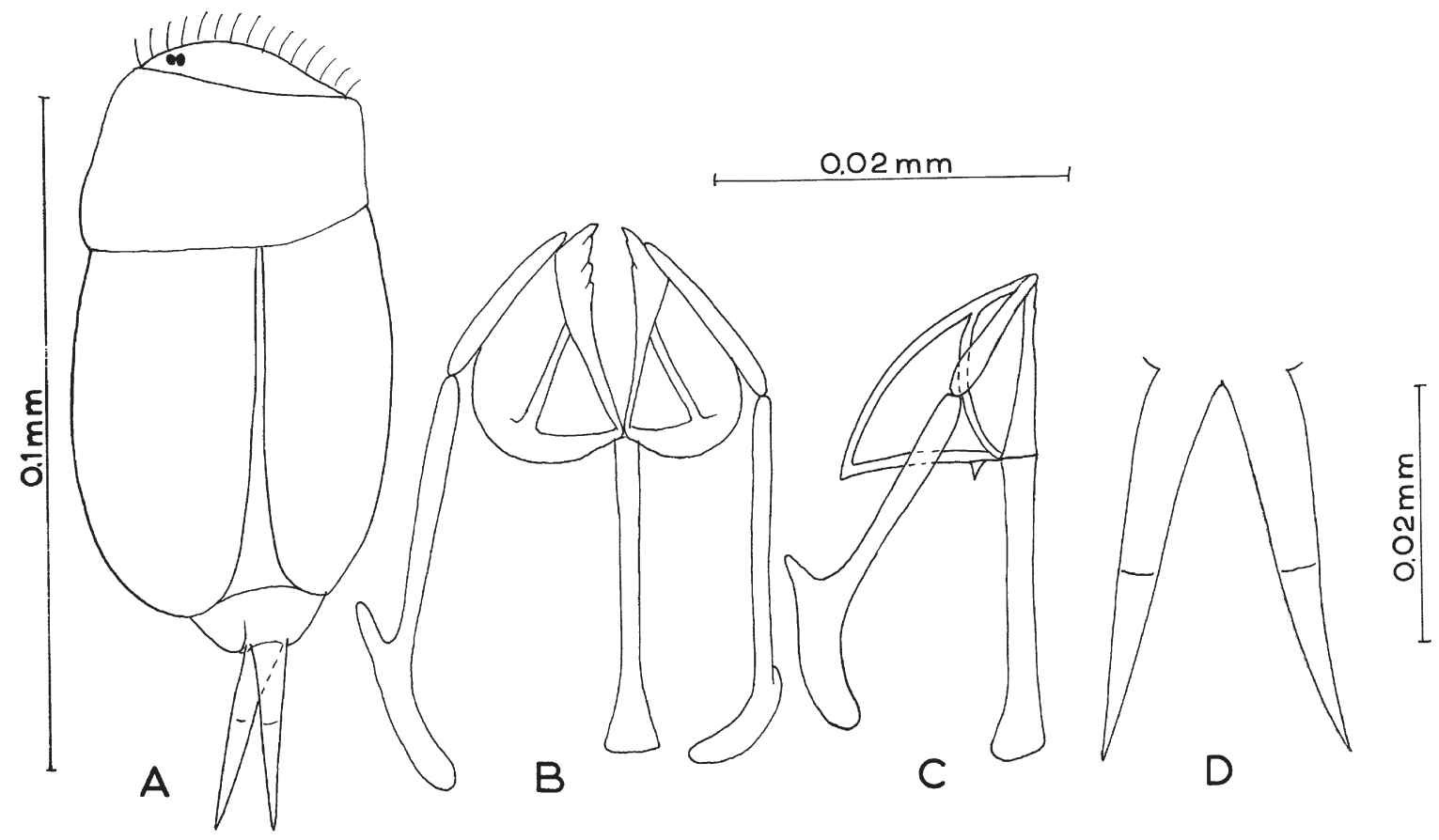

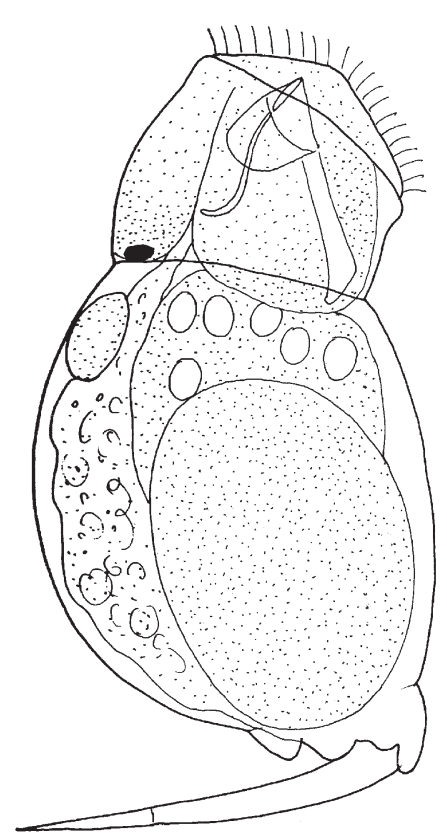

E
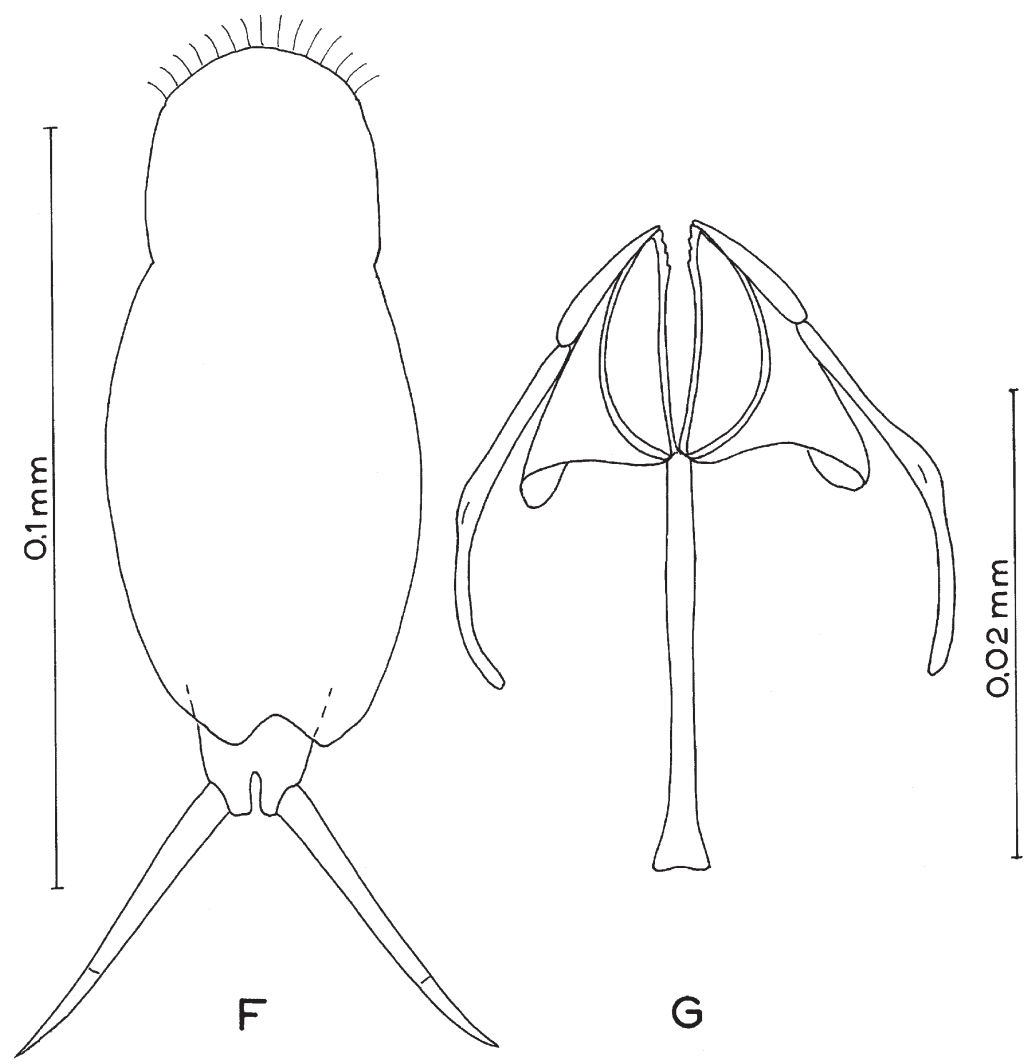

Figure I4. A-D: Cephalodella sterea. E-G: Cephalodella tantilloides. 

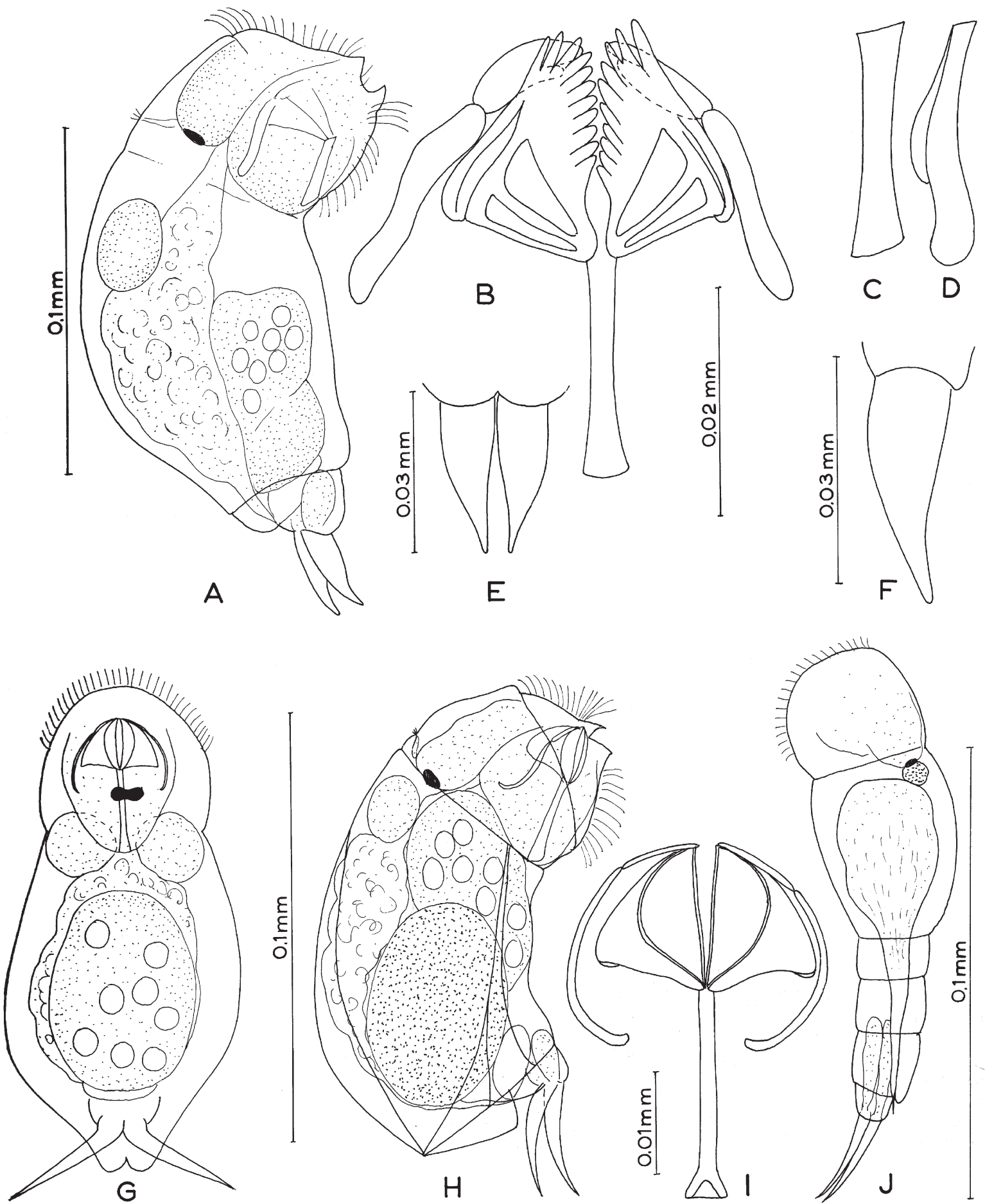

Figure 15. A-F: Cephalodella theodora, G-J: Cephalodella ventripes, J: male. 

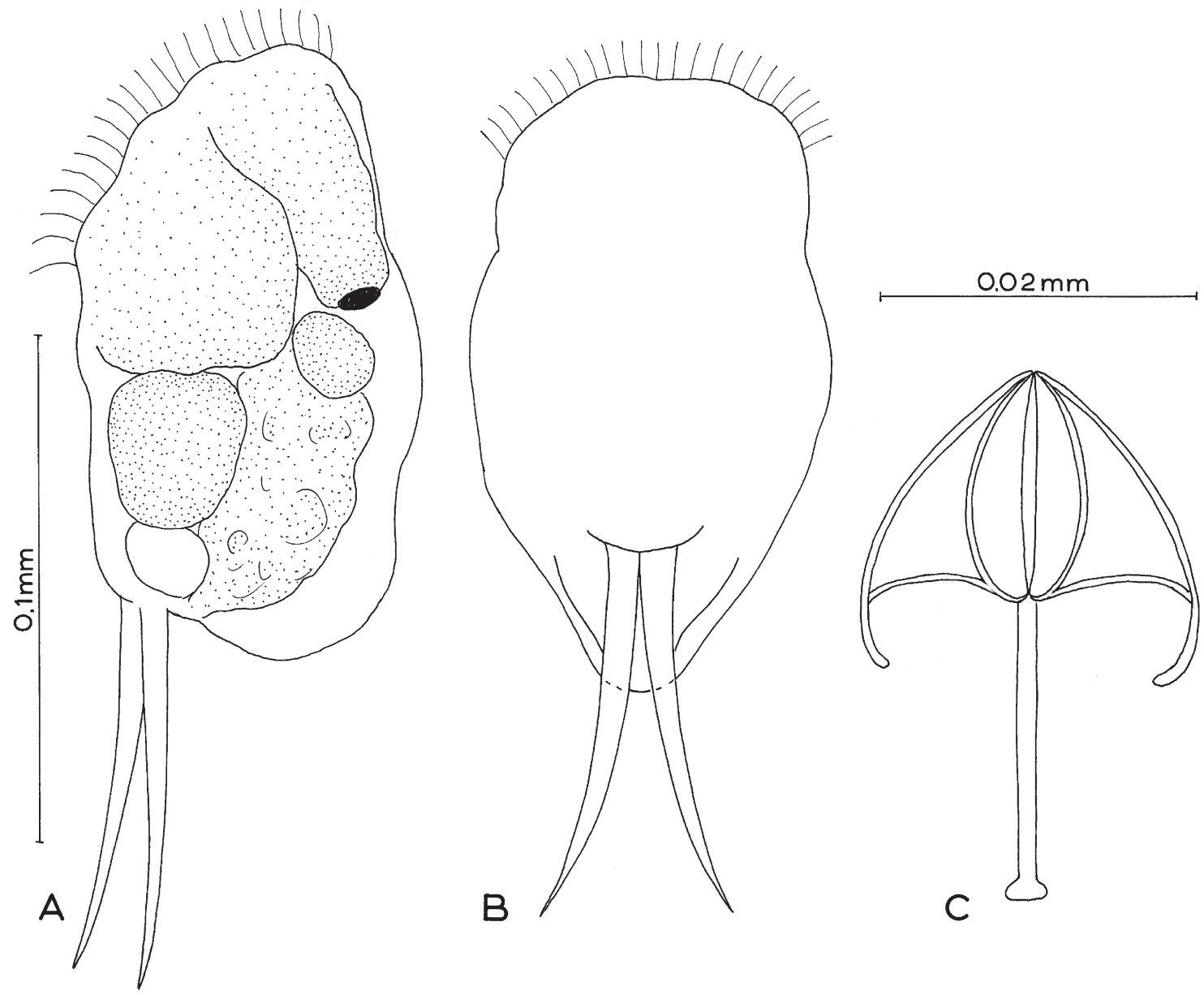

Figure 16. A-C: Cephalodella sp.

Notommata placida Harring \& Myers, 1922 1. $166-175 \mu \mathrm{m}$, t. $12-14 \mu \mathrm{m}, \operatorname{tr} 26-28 \mu \mathrm{m}(2)$

One specimen was found in a large bog pool and another in a tarn, both in Eksingedalen. They were a little contracted, and hence somewhat shorter than the one described from the USA. The trophi are of the same size, and quite similar. The symmetrical rami have several small teeth. No other records of this species seem to exist.

Trichocerca bidens (Lucks, 1912)

(Figure 19 A)

1.1. $200 \mu \mathrm{m}$, h. $76 \mu \mathrm{m}$, t. $56 \mu \mathrm{m}$ and $47 \mu \mathrm{m}$, tr. $65 \mu \mathrm{m}$ (1) A single specimen was found in the river in Eksingedalen. $T$. bidens resembles T. cavia (Gosse), but is generally considerably larger, and they can be distinguished by the former having a bent end on the left manubrium. A much smaller T. bidens was found on Edgeøya, Svalbard (De Smet et al. 1988).

\section{Trichocerca brachyura (Gosse, 1851)}

(Figure $20 \mathrm{~F}-\mathrm{I})$

1.1. $87-110 \mu \mathrm{m}$, h. $32-44 \mu \mathrm{m}$, t. $25-28 \mu \mathrm{m}$ and 23-26 $\mu \mathrm{m}$, tr. $29-$ $30 \mu \mathrm{m}(3)$

A few specimens were found in a shore pool with almost fresh water at Espegrend. The left front of the lorica protrudes characteristically. Four substyli are seen. The trophi have suprarami and a crutched left manubrium.

\section{Trichocerca cavia (Gosse, 1886)}

(Figure 19 B)

1.1. $136 \mu \mathrm{m}$, h. $62 \mu \mathrm{m}$, t. $32 \mu \mathrm{m}$ and $34 \mu \mathrm{m}$, tr. $63 \mu \mathrm{m}$ (1)

One specimen was found in the river in Eksingedalen and another in a mossy pool at Espegrend. It has also been found in several tarns near Bergen and on Hardangervidda (1.1. 92-126 $\mu \mathrm{m})$. The left manubrium is crutched and considerably smaller than in T. bidens. The right manubrium is shorter than in other specimens recorded. 

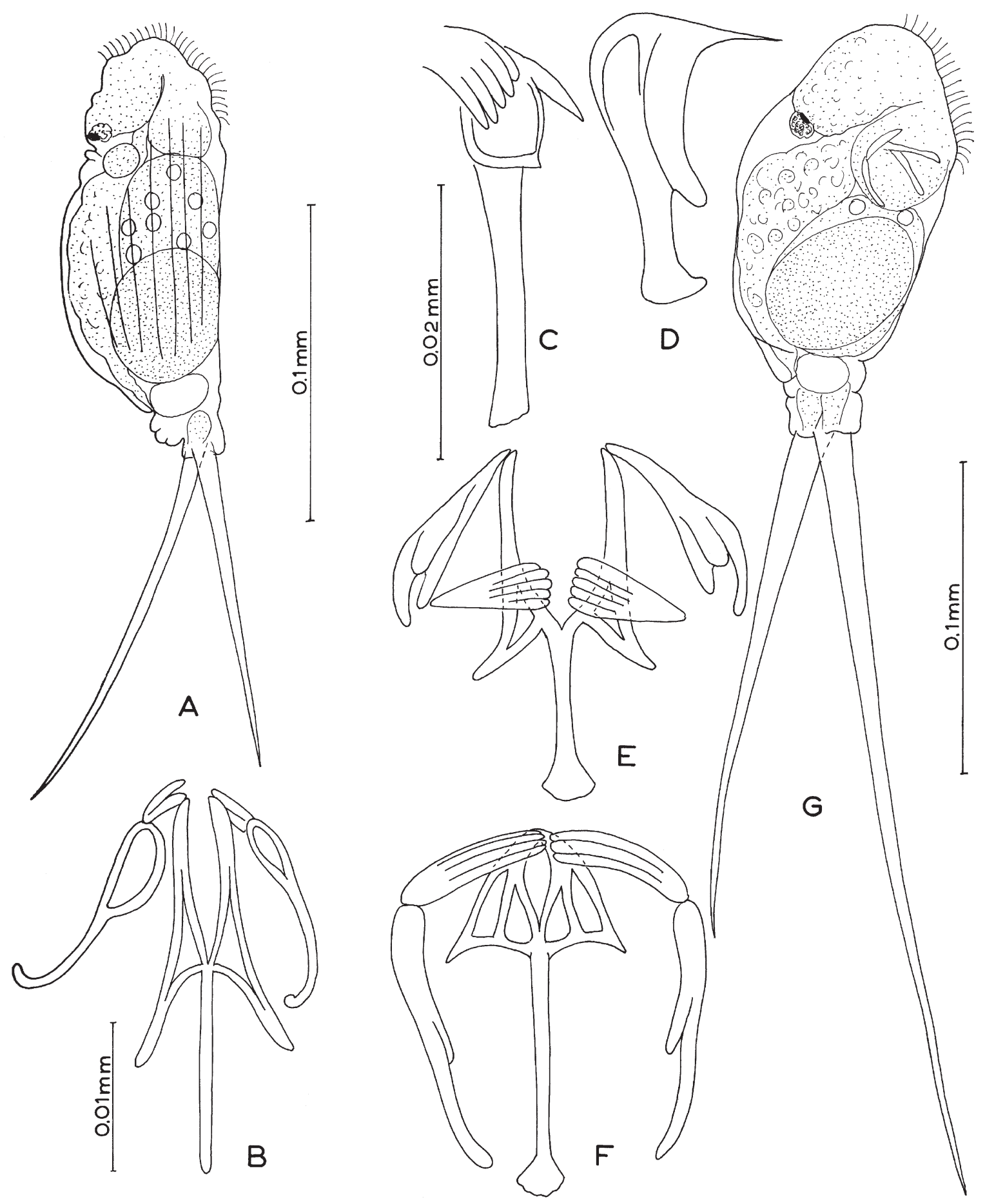

Figure 17. A-B: Monommata cf. actices. C-G: Monommata cf. phoxa, C and D: trophi parts laterally.. 


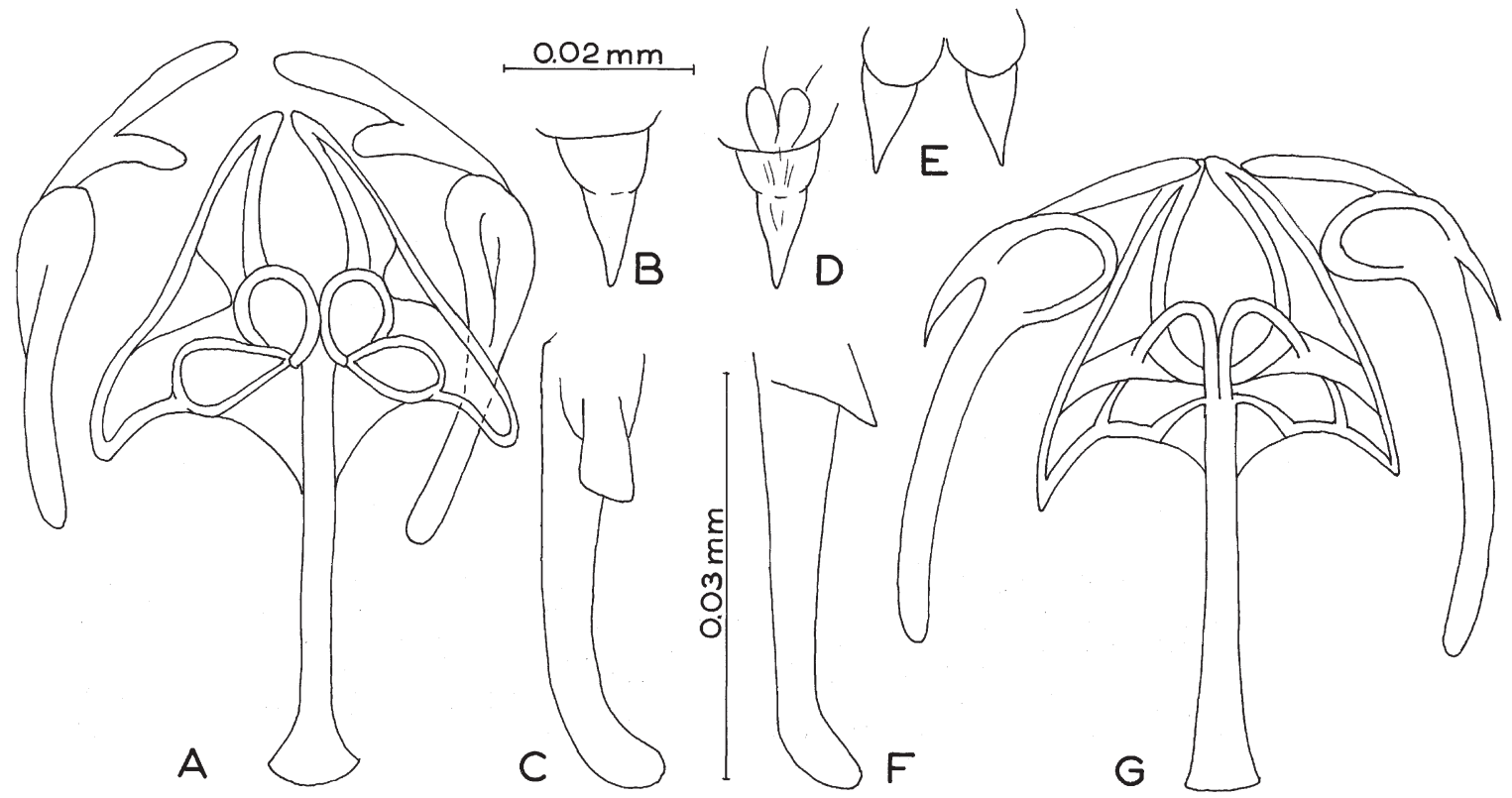

Figure 18. A-G: Resticula nyssa, A-C: from Teigdalen, D-G: from Eksingedalen, B, D, C, F: toe and fulcrum laterally.

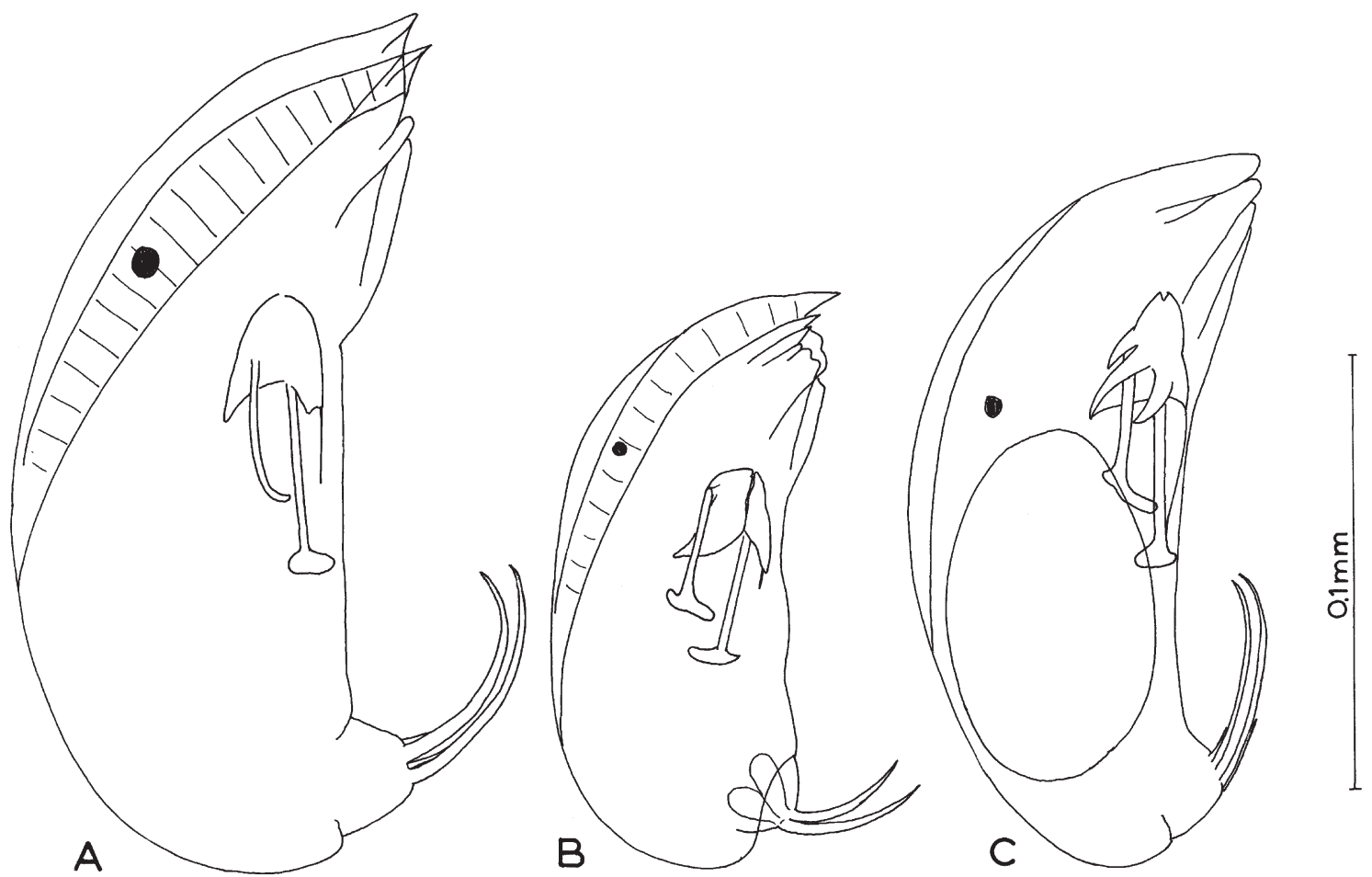

Figure 19. A: Trichocerca bidens. B: T. cavia. C: Trichocerca cf. collaris. 

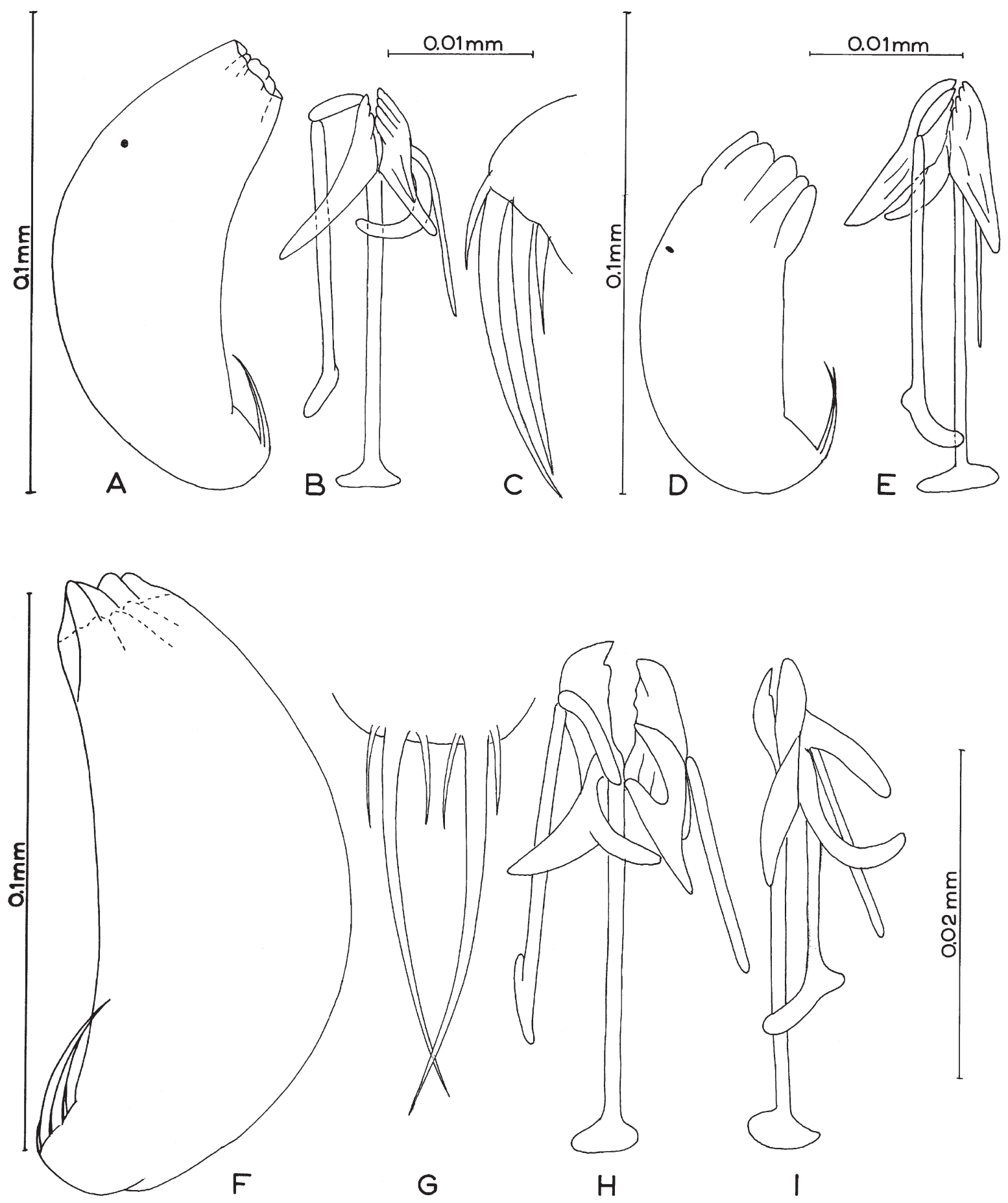

Figure 20. A-E: Trichocerca obtusidens, A-C: Espegrend specimens, D and E: small form. F-I: T. brachyura. 


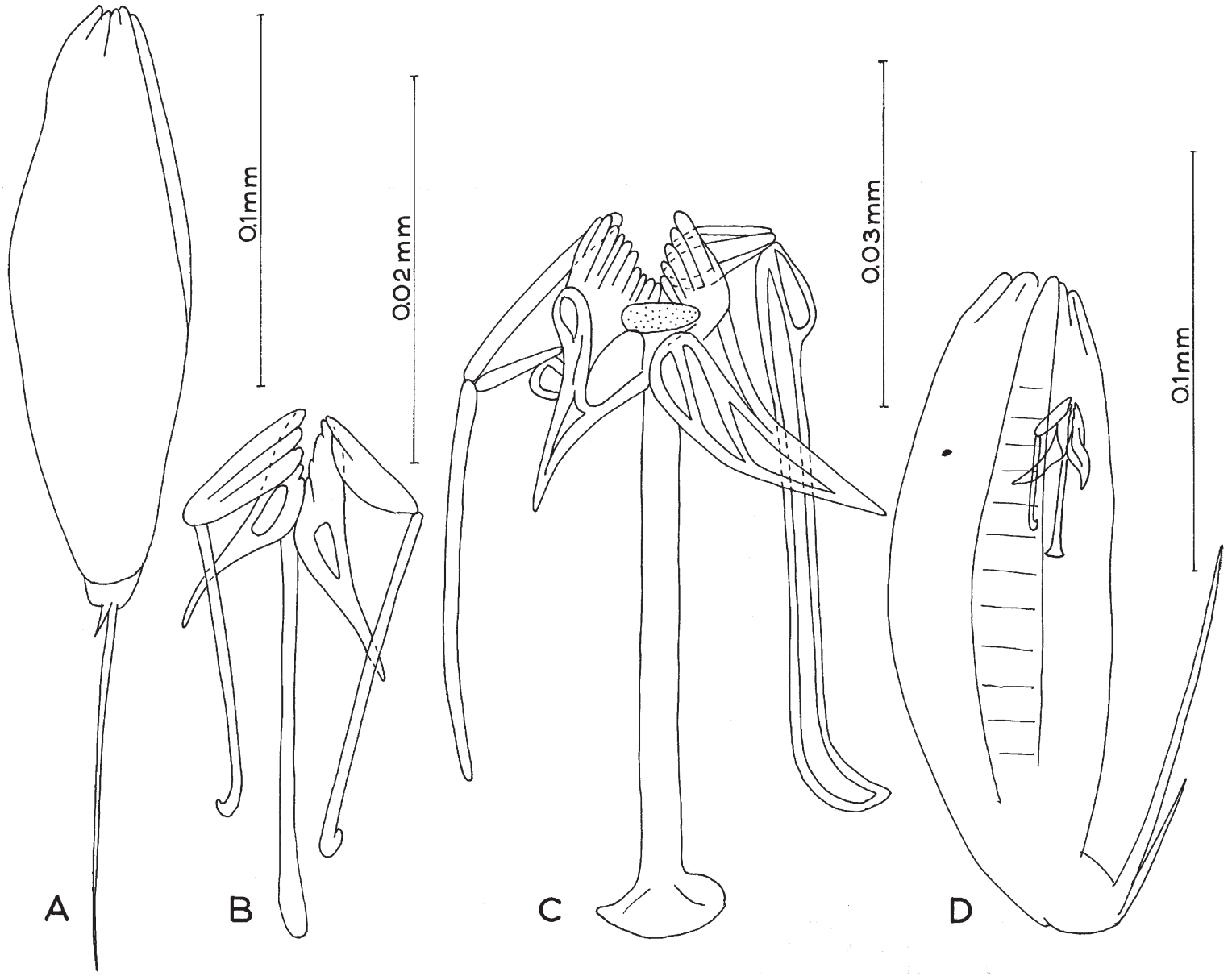

Figure 21. A and B: Trichocerca gracilis. C: Trichocerca lophoessa, trophi. D: Trichocerca sp. 1 (cf. mollis).

\section{Trichocerca cf. collaris (Rousselet, 1896) (Figure $19 \mathrm{C}$ )}

1.1. $170 \mu \mathrm{m}$, h. $64 \mu \mathrm{m}$, t. $52 \mu \mathrm{m}$ and $47 \mu \mathrm{m}$, tr. $63 \mu \mathrm{m}$ (1) A single specimen was found in a tarn in Eksingedalen. Its small size corresponds to that of T. collaris f. minor (Wulfert 1941), but the trophi are smaller. Koste (1978) proposed that that form, with its relatively large trophi, was a young individual. The present form, carrying an egg, is definitely an adult. The same small form was also found in a tarn on Hardangervidda and in southern Finland (Eriksen 1969). All these specimens have two substyli, not seen on other figures. The fulcrum and the crutched left manubrium resemble those shown (also incomplete and laterally) by Stenroos (1898), but the body and toe lengths of that specimen are much larger. The more complete trophi figure in a frontal position drawn by Koste (1978) does not show a marked crutch on the left manubrium.

\section{Trichocerca gracilis (Tessin, 1890) (Figure $21 \mathrm{~A}, \mathrm{~B}$ )}

1.1. $158-160 \mu \mathrm{m}$, t. $86-92 \mu \mathrm{m}$ and $10 \mu \mathrm{m}$, tr. $27 \mu \mathrm{m}$ (2) A few specimens were found in a small tarn above Grøndalsvatn.
The neck is almost not marked, and there is a low keel along more than half of the lorica. The shortest toe is somewhat shorter than recorded earlier. A figure of the trophi of T. gracilis does not seem to exist in the literature. The one shown in Figure 11-1b by Koste \& Shiel (1992) belongs to the similar T. iernis (Gosse) (Figure 2). The trophi parts of the present specimens are almost symmetrical. The fulcrum is very slightly expanded near the distal end. The rami have long alulae, "holes", and some teeth on the anterior parts. The manubria have curved distal ends. The unci have a few teeth.

\section{Trichocerca lophoessa (Gosse, 1886)} (Figure $21 \mathrm{C}$ )

1.1. $204 \mu \mathrm{m}, 86-92 \mu \mathrm{m}$ and 38-50 $\mu \mathrm{m}$ (5), tr. $65-70 \mu \mathrm{m}$ (2)

The species was found in small numbers at three places in the river in Eksingedalen and one in the river in Teigdalen. It was also found in a mossy pool at Espegrend from May to November, where it was sometimes quite numerous. The size and shape of the toes and lorica are characteristic, but a neck is not marked. There is a keel along most of the lorica length. I have not found any detailed figure of the trophi in the available literature, only a description (Koste 1978). This seems to correspond to my 

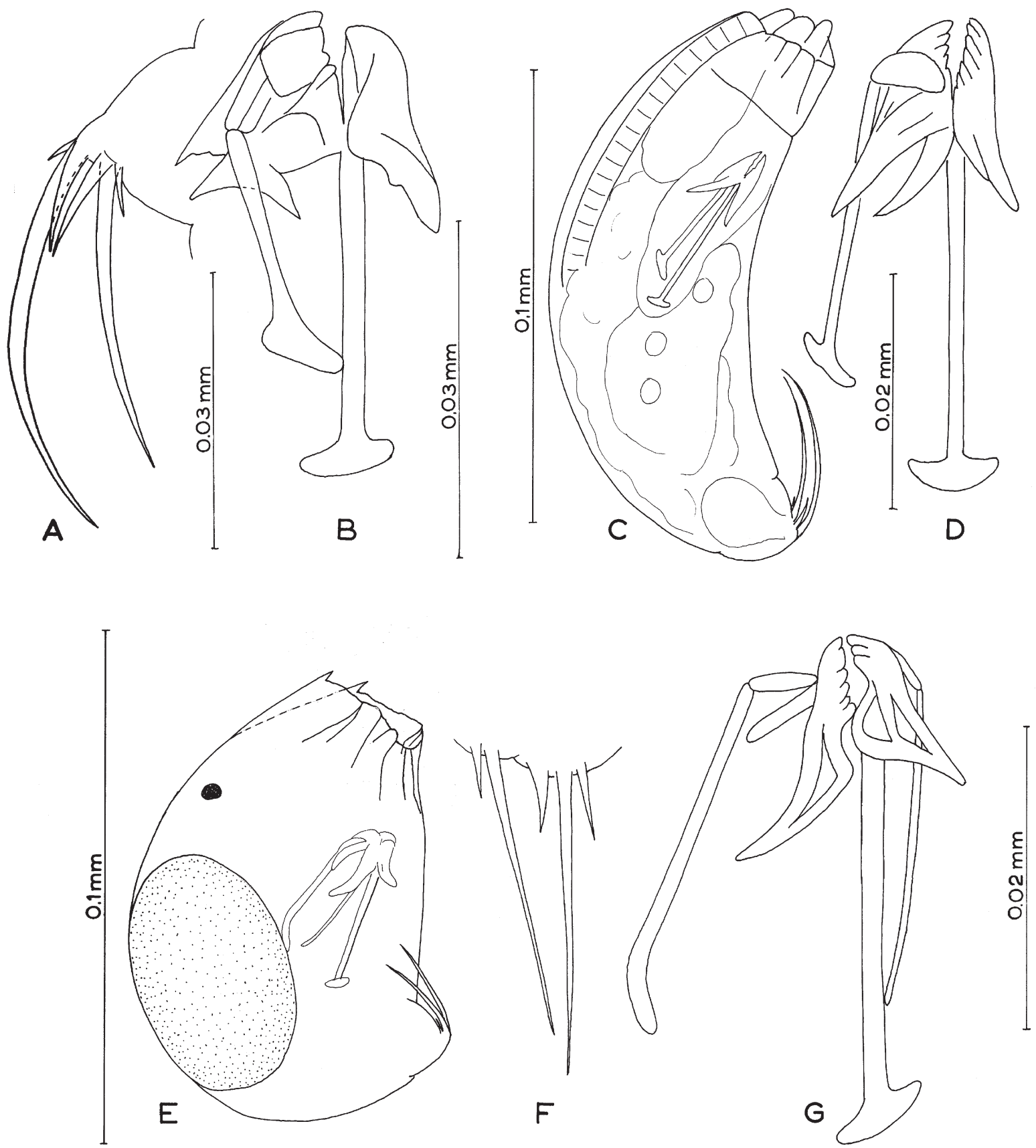

Figure 22. A and B: Trichocerca cf. musculus, toes and trophi. C and D: Trichocerca obtusidens, large form. E-G: T. sp. 2.

figure of the trophi, which are fairly asymmetrical.

Trichocerca cf. musculus (Hauer, 1936)

(Figure $22 \mathrm{~A}, \mathrm{~B}$ )

t. $42 \mu \mathrm{m}$ and $35 \mu \mathrm{m}$, tr. $42 \mu \mathrm{m}$ (1)

A single specimen was found in a flooded river bend in Eksingedalen. Only the toes and trophi have been studied. The broad left ramus with three alulae differs slightly from that shown by Hauer (1936). The short right manubrium is not seen.

Trichocerca obtusidens (Olofsson, 1918)

(Figures $20 \mathrm{~A}-\mathrm{E}, 22 \mathrm{C}, \mathrm{D}$ )

Small form (Fig. 20 D, E): 1.1. $72-74 \mu \mathrm{m}$, t. $20 \mu \mathrm{m}$ and $19 \mu \mathrm{m}$, tr. $26-28 \mu \mathrm{m}(2)$

Medium form (Fig. 22 A-C): 1.1. 92-110 $\mu \mathrm{m}$, t. 23-27 $\mu \mathrm{m}$ and 


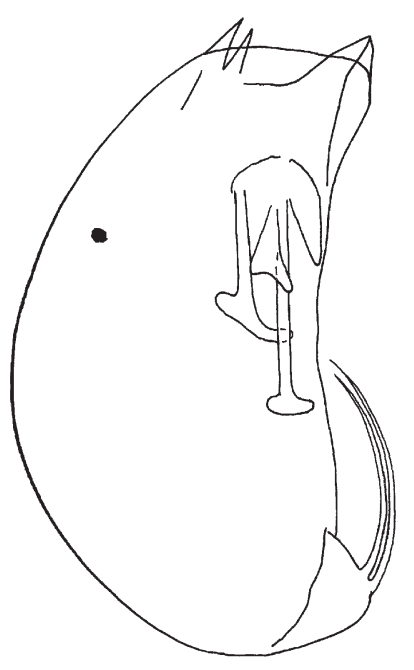

A
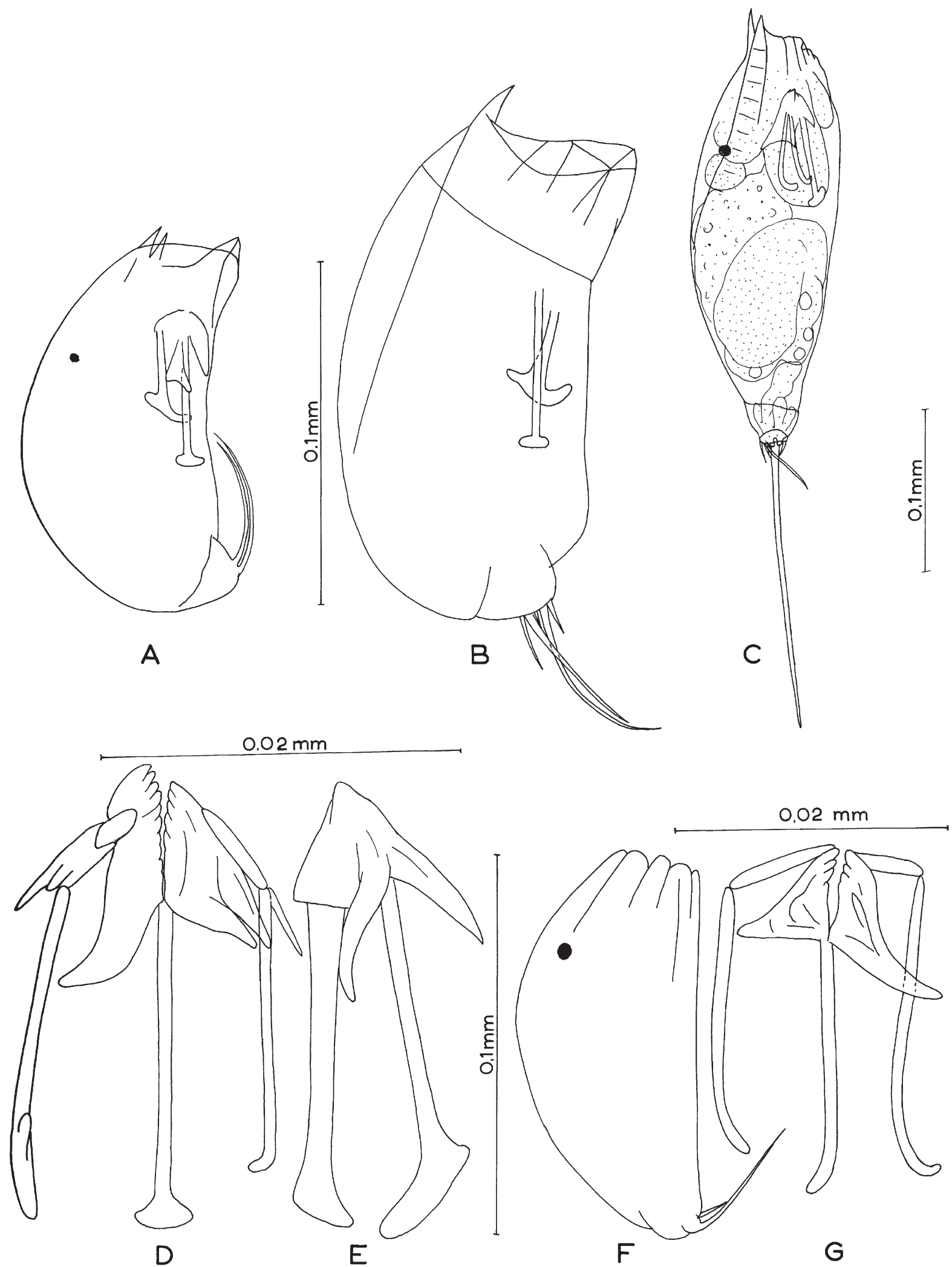

Figure 23. A and B: Trichocerca porcellus, A: small form, B: large form. C: Trichocerca $\mathrm{cf}$. rosea. D and E: Trichocerca cf. siamensis. F and G: Trichocerca cf. pusilla. 


\section{0-26 $\mu \mathrm{m}$, tr. $27-30 \mu \mathrm{m}(9)$}

Large form (Fig. 22 C, D): 1.1. 115-122 $\mu \mathrm{m}$, t. 37-39 $\mu \mathrm{m}$ and 26-

$30 \mu \mathrm{m}$, tr. $36-40 \mu \mathrm{m}(3)$

The smallest specimens were found in three tarns in Eksingedalen. The medium-sized specimens were fairly common in a few pools with almost fresh water at Espegrend. These two size groups resemble the species described as Diurella arctica by Olofsson (1918) from Spitsbergen, but without any trophi figure. The literature of the similar $T$. relicta shows trophi figures which are rather similar to those present here, mostly showing a short right manubrium.

The largest specimens were found at several localities in both rivers. The size and shape of the lorica and toes agree very well with the species described by Olofsson (1918) as Diurella obtusidens, also from Spitsbergen and without a trophi figure. I have found more specimens like this in two small lakes near Bergen and a tarn on Hardangervidda (1.1. 107-124 $\mu \mathrm{m}$, t. 22-34 $\mu \mathrm{m}$ (11) and 20-32 $\mu \mathrm{m}$ tr. 26-37 (4). A shorter or longer keel was sometimes seen. The short right manubrium was not observed on that form. According to De Smet (1988) and Segers (2003), all three forms are variations of T. obtusidens.

\section{Trichocerca porcellus (Gosse, 1886)}

(Figure $23 \mathrm{~A}, \mathrm{~B}$ )

Small form (Fig. 23 A): 1.1. 114-123 $\mu$ m, h. 56-59 $\mu$ m, t. 38-43 $\mu \mathrm{m}$ and 32-35 $\mu \mathrm{m}(2)$, tr. $47 \mu \mathrm{m}(1)$

Large form (Fig. 23 B): 1.1. $157 \mu \mathrm{m}$, h.70 $\mu \mathrm{m}$, t. $50 \mu \mathrm{m}$ and 44 $\mu \mathrm{m}, \operatorname{tr} .65 \mu \mathrm{m}(1)$

The small form was found at two localities connected with the river in Teigdalen. The toes differed in length, and substyli were seen on only one specimen. Some similar specimens were also found in a tarn near Bergen (1.1. 114-117 $\mu \mathrm{m}, \mathrm{h} .48-58 \mu \mathrm{m}$, left t. $38-43 \mu \mathrm{m}$, right t. a little shorter (3)).

A single large specimen was found in a tarn in Eksingedalen. It has a keel on about $2 / 5$ of the lorica. Only one spine was observed in the dorsal front, but the smaller right one could have been concealed behind the left one. The ventral front was typically protruding. On the trophi, only the fulcrum and left manubrium were studied, and these were of typical shape. Two substyli were seen. A similar, large specimen was also found in a tarn near Bergen (1.1. $173 \mu \mathrm{m}$, h. $82 \mu \mathrm{m}$, t. $54 \mu \mathrm{m}$ and 50 $\mu \mathrm{m})$.

\section{Trichocerca cf. pusilla (Jennings, 1903)} (Figure 23 F, G)

$$
\text { 1.1. } 70-114 \mu \mathrm{m} \text {, h. } 32-78 \mu \mathrm{m}, \text { t. } 32-40 \mu \mathrm{m} \text { and 10-20 } \mu \mathrm{m} \text { (12), tr. }
$$$$
25-27 \mu \mathrm{m}(5)
$$

The species was found in great numbers in open water in a large pool with almost fresh water on an islet at Espegrend. Its maximum abundance was in late spring and early summer in both years when sampling took place. It also occurred sporadically in a few other pools. The length of the lorica corresponds to that reported by Koste (1978) for T. pusilla, but the toes are shorter. The trophi (better seen in Koste \& Shiel (1992)) mostly correspond to the present figure. The shape of the rami, the terminally bent fulcrum and the bent left manubrium agrees, but the right manubrium differs, being weakly bent and almost as long as the left one. A bent right manubrium is also seen on the SEM micrograph published by Sanoamuang \& Stout (1993), but the fulcrum end looks to be more extended. Two teeth on each uncus could mostly be seen. Both the size and the toe length correspond well with $T$. cf. stylata drawn by Pejler (1957), but without a trophi figure. The lorica was often rounder on fully adult individuals, especially when carrying an egg.

\section{Trichocerca cf. rosea (Stenroos, 1898)}

(Figure $23 \mathrm{C}$ )

\section{1. $270 \mu \mathrm{m}$, h. $89 \mu \mathrm{m}$, t. $178 \mu \mathrm{m}$ and $40 \mu \mathrm{m}$, tr. $73 \mu \mathrm{m}$ (1)}

A single specimen was found in a bog pool in Eksingedalen. The size and shape of the lorica and toes are rather characteristic. The trophi, seen laterally, show roughly asymmetrical rami, extended fulcrum ends and two distally bent manubria of almost the same length. The original description (Stenroos 1898) roughly shows the trophi in a ventral position, and both manubria seem to have somewhat bent ends (not easily seen in that position). Koste \& Shiel (1992) show a shorter, straight, right manubrium.

\section{Trichocerca cf. siamensis Segers \& Polpunthin, 1997 (Figure $23 \mathrm{D}, \mathrm{E}$ ) \\ 1.1. (without spine) $74 \mu \mathrm{m}, \mathrm{h} .30 \mu \mathrm{m}$, t. $18 \mu \mathrm{m}$, tr. $25-27 \mu \mathrm{m}, \mathrm{m}$. $18 \mu \mathrm{m}$ and $15 \mu \mathrm{m}(1)$}

A single specimen was found among vegetation on the shore of the river mouth at Evangervatn. Because it died when extended, any frontal spine on the lorica was not distinguished. The size and shape of the body, toes and trophi correspond fairly well to those of the species described by Segers \& Polpunthin (1997) from Thailand and Brazil. Similar specimens were also found a small lake near Bergen (1.1. 64-70 $\mu \mathrm{m}$, h. $32 \mu \mathrm{m}$, t. $17-18 \mu \mathrm{m}$, sp. $18 \mu \mathrm{m}(3)$, tr. $23 \mu \mathrm{m}, \mathrm{m} .18 \mu \mathrm{m}$ and $14 \mu \mathrm{m}(1))$. Both extended and contracted specimens were found, also showing the frontal spine. The "knob" on the left manubrium was in the same position as figured by Segers \& Polpunthin (1997). Segers (2003) claimed that $T$. siamensis is a typical warm-water species. My specimens were living in temperatures of 12.5 and $17.0^{\circ} \mathrm{C}$.

\section{Trichocerca sp.1 (cf. T. mollis (Edmondson, 1936))} (Figure $21 \mathrm{D}$ )

1.1. $160-162 \mu \mathrm{m}$, h. $53-58 \mu \mathrm{m}$, t. $85-86 \mu \mathrm{m}$ and 34-36 $\mu \mathrm{m}$ (2), tr. $38 \mu \mathrm{m}(1)$

A few specimens were found in a small lake and a tarn in Eksingedalen. The species shows some similarity to T. mollis (Edmondson 1936), but is a little larger. The right toe is also longer, about $2 / 5$ of the longest one. Slide 818 in AMNH shows three specimens named $T$. mollis with a similar size and shape to those of the original description, but also with a longer right 

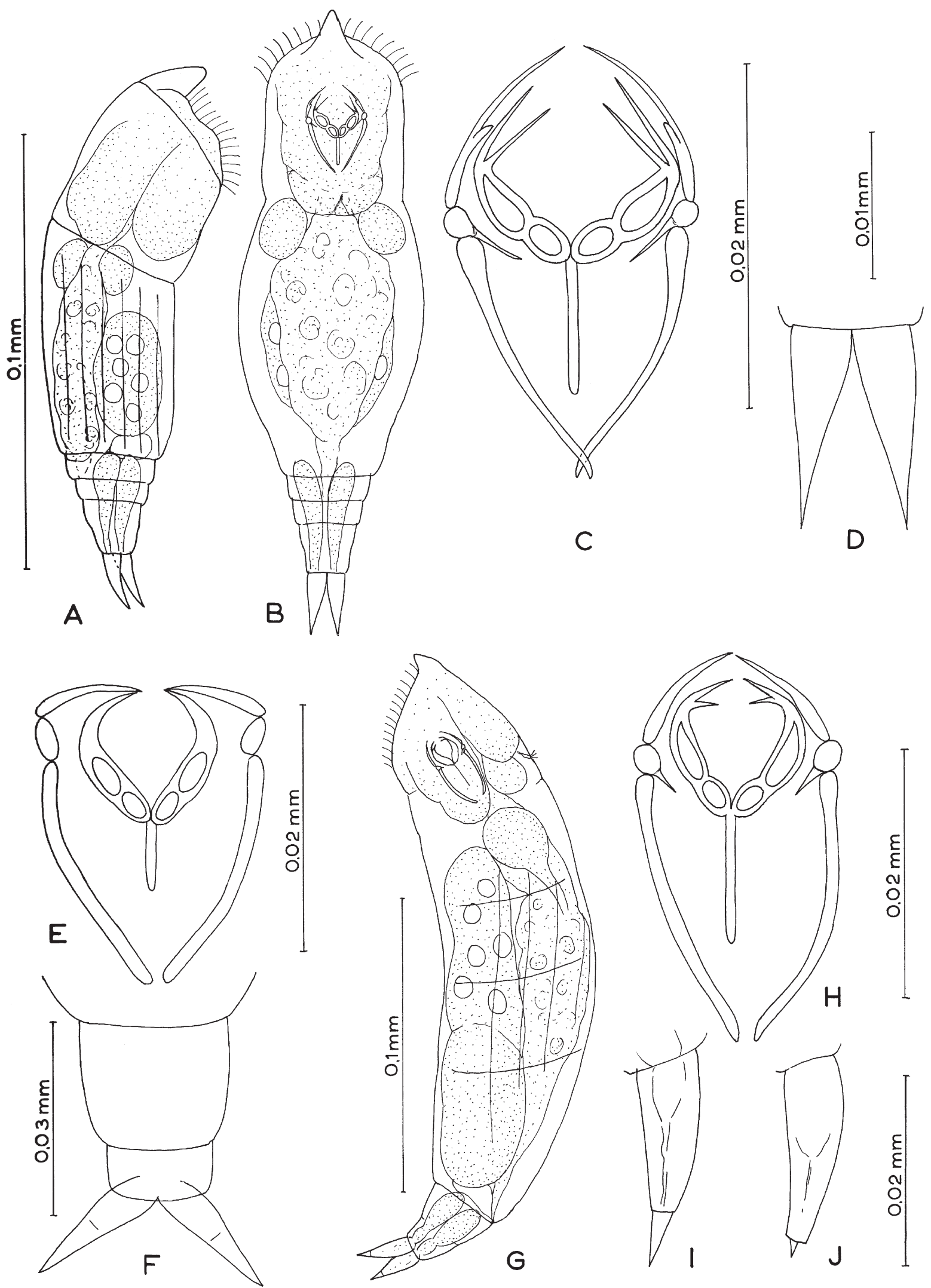

Figure 24. Figure 24. A-D: Encentrum mustela, A: young specimen, B: older specimen. E and F: Encentrum arvicola, trophi and foot with toes. G-J: Encentrum putorius, J: toe with tip withdrawn. 
toe. No trophi are shown on those specimens. The present trophi seem to show the left manubrium bent, no right manubrium, a fulcrum with an extended end, and rather asymmetrical rami. Segers (2003) recorded T. mollis from South America, also showing its trophi. They differ considerably from those of the present one, however, and the left toe is short.

The species was also found in three tarns around Bergen and one on Hardangervidda. (1.1. 135-162 $\mu \mathrm{m}$, h. 39-53 $\mu \mathrm{m}$, t. 78-92 $\mu \mathrm{m}$ and 26-32 $\mu \mathrm{m}$ (9), tr. 36-43 $\mu \mathrm{m}$ (4)). The neck is sometimes marked, and a keel or a striated area is occasionally seen. This may be a new subspecies, or even species.

\section{Trichocerca sp. 2}

(Figure 22 E-G)

\section{1. $89-91 \mu \mathrm{m}$, t. $21-23 \mu \mathrm{m}$, tr. 33-34 $\mu \mathrm{m}$ (2), h. $56 \mu \mathrm{m}$ (1)}

A few specimens were found in a mossy pool at Espegrend. The body looks rather plump, perhaps because of some degree of compression, and also the large egg inside it. The toes, front and trophi are rather characteristic. It does not seem to correspond to any other species seen in the available literature, and may be a new species.

\section{Encentrum arvicola Wulfert, 1936}

(Figure $24 \mathrm{E}, \mathrm{F}$ )

1. $170 \mu \mathrm{m}$ (a little contracted), t. $20 \mu \mathrm{m}$, tr. $26 \mu \mathrm{m}$ (1) A few specimens were found in the river in Teigdalen. The body was not studied in detail, but the trophi agree well with the figure given by Wulfert (1936). The foot is two-jointed, with the anterior joint rather long. The toes have weakly marked septa about midway.

\section{Encentrum mustela (Milne, 1885)}

(Figure 24 A-D)

1. $125-140 \mu \mathrm{m}$, t. $22-25 \mu \mathrm{m}$, tr. $22-25 \mu \mathrm{m}$, r. $10 \mu \mathrm{m}$, f. $8 \mu \mathrm{m}$, u. 12-13 $\mu \mathrm{m}, \mathrm{m} .13-16 \mu \mathrm{m}, \mathrm{s} . \mathrm{m} .3-4 \mu \mathrm{m}(2)$

Two specimens were found in a lake-like part of the river in Eksingedalen. The young one had a strikingly large head relative to its trunk, which had longitudinal folds and small internal organs. The older one was considerably longer, with larger organs (perhaps also a little extended). There were two short pseudo-segments on the distal part of the abdomen, and a longer foot segment. The large pedal glands extended through all the segments. De Smet (1997), for the first time, showed the supramanubria on his trophi figure. On the present specimens, they are more straight and slender, pointing obliquely backwards.

\section{Encentrum putorius Wulfert, 1936} (Figure $24 \mathrm{G}-\mathrm{J}$ )

1. $210-230 \mu \mathrm{m}$, t. $21-23 \mu \mathrm{m}$, tr. $31-33 \mu \mathrm{m}(3)$

The species was common at two sites in the river in Teigdalen in April at $2{ }^{\circ} \mathrm{C}$. The present specimens are considerably smaller than those described by Wulfert (1936), but longer than the smallest measurement given by Koste \& Terlutter (2001). The shape of the body and trophi corresponds quite well with those on the other figures. The toe tips could be withdrawn.

\section{Distribution in habitat categories}

There were a number of differences in the distribution and abundance of species between the categories of habitat (Table 3). Category III had most species and by far the highest number of species found only once during the investigation. Category IV also had many species, and had the most samples and species with abundance levels 2 and 3. Category I, however, had the highest mean number of species per sample. It had a somewhat higher mean value (13.1) when the three small pools were excluded (leaving only the large bog pool, one small lake and five tarns). Relative to the number of samples taken, this category also had the highest total number of species and of species found only there. Category II had the fewest species and the lowest number of species found only there, and found only once.

The species composition also varied to a certain extent between the various categories of habitat. Most localities were acid, but with some gradients in $\mathrm{pH}$ and trophic degree down the valleys. Some correlation has been proposed between the composition of the rotifer fauna and these two factors, which often accompany each other (low pH - low trophic degree). Berzins \& Pejler $(1987,1989)$ processed a large amount of data from Sweden and found no particularly strong correlation between the rotifers and those factors. Most species tolerated a very broad range of variation. Only two species of those typically occurring in acid water were found in the present investigation: Polyarthra minor (category I) and Kerratella serrulata (categories I and II). However, many of the species found are rare and nothing can be said about their affinities to environmental factors.

\section{Disparity in species composition between samples}

The variation in the species composition on the same date at localities situated rather close to one another was considerable, and it could differ even more at the same locality on different dates. Sudden variations in the water level caused by heavy rain alternating with drier periods gave changing habitat conditions in the shore zones. After some days of heavy rain, it might be impossible to repeat a collection from a certain site, and after several sunny days, a previously flooded site might be dry land.

Some examples are given (abundance levels 2 or 3 in brackets, otherwise level 1. m - males seen, r. e. - resting eggs seen):

\section{Neighbouring localities, river area in Eksingedalen}

Loc. 6a - shallow shore of a lake-like stretch of river at Lavik $-\mathrm{pH}$ 5.5:

Euchlanis dilatata, E. lyra, E. triquetra, Colurella obtusa, C. sulcata, Proalinopsis squamipes, Cephalodella delicata, C. cf. dentata, C. forficata, C. tantilloides (2), C. ventripes (2, m), C. sp. (a small one), Trichocerca bidens, T. lophoessa, Encentrum mustela 
Table 2. Species list with sampling localities or areas and habitat categories. The distribution in the two valleys is denoted by the number of records in each of the categories I - IV. In the slightly brackish-water localities near Bergen (locs. 35, 36, 37, 38), category V, + means one or more records. The species included from later collections in freshwater are only marked with the area: B (Bergen) and $\mathrm{H}$ (Hardangervidda). Bold denotes species new to Norway, and * species new to Hordaland.

\begin{tabular}{llllllllll}
\hline Localities or areas & I & II & III & IV & V & \\
\hline
\end{tabular}

\section{PHILODINIDAE}

Philodina citrina Ehrenberg, $1832 \quad 36$

P. roseola Ehrenberg, $1832 \quad 36$

Rotaria rotatoria (Pallas, 1766) $\quad 36$

\section{EPIPHANIDAE}

Microcodides chlaena (Gosse, 1886)* $\quad 6 \mathrm{~b}$

M. sp.

$6 \mathrm{~b}$

\section{BRACHIONIDAE}

Brachionus calyciflorus Pallas, 1776*

\section{B. quadridentatus Hermann, 1783}

B. rubens Ehrenberg, 1838

B. urceolaris (Müller, 1773)

Kellicottia longispina (Kellicott, 1879)

Keratella cochlearis (Gosse, 1851)

K. hiemalis Carlin, 1943*

K. paludosa (Lucks, 1912)

K. quadrata (Müller, 1786)

K. serrulata (Ehrenberg, 1838)

Notholca acuminata (Ehrenberg, 1832)

N. labis Gosse, 1887*

N. squamula (Müller, 1786)

6
6
6

\section{EUCHLANIDAE}

\section{Euchlanis alata Voronkov, 1912}

E. dilatata Ehrenberg, 1832

E. lyra Hudson, 1886

E. meneta Myers, 1930

E. oropha Gosse, 1887

E. triquetra Ehrenberg, 1838

Tripleuchlanis plicata Levander, 1894

\section{MYTILINIDAE}

Mytilina unguipes (Lucks, 1912)

M. ventralis brevispina (Ehrenberg, 1832)*

M. videns (Levander, 1894)*

35

B

B

36

19a, 23b, c, 32, 33, 34b

$21 \mathrm{c}$

19b, 20, 21c, 23b, 32, 33, 34b

B

35,38

$5,7,13,19 \mathrm{~b}, 20$

$35,36,37$

28

22, 23c, 29a, 30b, 32

$11,22,23 b, 25,26$

$2,4,6 \mathrm{~b}, 8,13,15,23 \mathrm{c}, 25,26$

$2,6 \mathrm{a}, 8,36$

2

$11,34 \mathrm{a}$

3, 6a, 13, 15, 21b, 22, 23a, c, 24, 26

25

B

$\mathrm{H}$

5,32

$3,4,9,12,15,19 \mathrm{~b}$

$23 \mathrm{a}$

$1,5,7,13,31 \mathrm{a}$

36

36

1, 6a, 7, 24, 25

$1,6 \mathrm{a}, 7,24,25$

$\begin{array}{lllll}- & - & - & - & + \\ - & - & - & - & - \\ - & - & - & - & - \\ - & - & - & - & + \\ - & 5 & - & 1 & - \\ - & 1 & - & - & - \\ - & 5 & - & 1 & - \\ - & - & - & - & - \\ - & - & - & - & + \\ 4 & 1 & - & - & - \\ - & - & - & - & + \\ - & - & 1 & - & - \\ - & 2 & - & 3 & -\end{array}$

\section{TRICHOTRIDAE}

Trichotria tetractis caudata (Lucks, 1912)

T. t. similis (Stenroos, 1898)

T. truncata (Whitelegge, 1889)

\section{LEPADELLIDAE}

Colurella anodonta (Carlin, 1939)

C. colurus (Ehrenberg, 1830)*

C. obtusa (Gosse, 1886) 


\begin{tabular}{|c|c|c|c|c|c|c|}
\hline & Localities or areas & I & II & III & IV & $\mathrm{V}$ \\
\hline C. sinistra Carlin, 1939 & 36,38 & - & - & - & - & + \\
\hline C. sulcata (Stenroos, 1898)* & $6 a$ & - & - & 1 & - & - \\
\hline C. tessella (Glascott, 1893) & $1,7,18 b, 24,25,31 b$ & 4 & - & - & 2 & - \\
\hline Lepadella acuminata (Ehrenberg, 1832) & $3,8,11,13,17,29 b, 36$ & 1 & - & 4 & 1 & + \\
\hline L. dactyliseta (Stenroos, 1898) & $\mathrm{H}$ & - & - & - & - & - \\
\hline L. glossa Wulfert, 1960 & $\mathrm{H}$ & - & - & - & - & - \\
\hline L. ovalis Müller, 1786 & 36 & - & - & - & - & + \\
\hline L. patella patella (Müller, 1786) & $4,9,11,15,29 b, 30 b, 36$ & - & - & 5 & 2 & + \\
\hline L. p. oblonga (Ehrenberg, 1834)* & $\mathrm{H}$ & - & - & - & - & - \\
\hline L. p. persimilis De Ridder, 1961 & 36 & - & - & - & - & + \\
\hline L. quadricarinata (Stenroos, 1898)* & 36 & - & - & - & - & + \\
\hline L. rottenburgi (Lucks, 1912) & $7,18 \mathrm{a}$ & - & 2 & - & - & - \\
\hline L. triptera (Ehrenberg, 1838) & 38 & - & - & - & - & + \\
\hline L. venefica Myers, 1934 & $\mathrm{H}$ & - & - & - & - & - \\
\hline \multicolumn{7}{|l|}{ LECANIDAE } \\
\hline L. agilis (Bryce, 1892) & B & - & - & - & - & - \\
\hline L. cf. clara (Bryce, 1892) & 20 & - & 1 & - & - & - \\
\hline L. closterocerca (Schmarda, 1859) & 22,36 & - & - & 1 & - & + \\
\hline L. depressa (Bryce, 1891) & $\mathrm{B}$ & - & - & - & - & - \\
\hline L. flexsilis (Gosse, 1886) & 38 & - & - & - & - & + \\
\hline L. intrasinuata (Olofsson, 1917) & 5,12 & 2 & - & - & - & - \\
\hline L. lauterborni Hauer, 1924 & $21 \mathrm{a}$ & - & 1 & - & - & - \\
\hline L. levistyla (Olofsson, 1917)* & $\mathrm{H}$ & - & - & - & - & - \\
\hline L. ligona (Dunlop, 1901) & $21 b$ & - & 1 & - & - & - \\
\hline L. luna (Müller, 1776) & 38 & - & - & - & - & + \\
\hline L. lunaris (Ehrenberg, 1832) & $\begin{array}{l}\text { 7, 12, 13, 16, 18a, b, 19a, b, 21a, } \\
\text { 30a, 31a, 34a, 36 }\end{array}$ & 7 & 3 & 1 & 1 & + \\
\hline L. acus Harring, 1913 & $21 \mathrm{a}$ & - & - & 1 & - & - \\
\hline L. perplexa (Ahlstrom, 1938) & $3,18 \mathrm{a}, 19 \mathrm{~b}, 36$ & 1 & 1 & 1 & - & + \\
\hline L. mira (Murray, 1913) & 16 & - & - & 1 & - & - \\
\hline L. rhacois Harring \& Myers, 1926 & $\mathrm{~B}$ & & & & & \\
\hline L. scutata (Harring \& Myers, 1926) & $\mathrm{H}$ & - & - & - & - & - \\
\hline L. signifera ploenensis (Voigt, 1902) & $20,31 \mathrm{a}$ & 2 & - & - & - & - \\
\hline L. stichaea (Harring, 1913) & $1,4,5,7,12,18 b, 31 b$ & 6 & - & 1 & - & - \\
\hline \multicolumn{7}{|l|}{ PROALIDAE } \\
\hline Bryceela tenella (Bryce, 1897) & $\mathrm{B}$ & - & - & - & - & - \\
\hline Proales fallaciosa Wulfert, 1937 & 12 & 1 & - & - & - & - \\
\hline Proalinopsis caudatus (Collins, 1872) & $6 b, 15,23 a$ & - & - & 2 & 1 & - \\
\hline P. squamipes Hauer, 1935 & $6 a, 11$ & - & - & 2 & - & - \\
\hline \multicolumn{7}{|l|}{ LINDIIDAE } \\
\hline Lindia cf. pallida Harring \& Myers, 1922 & $7,31 b$ & 2 & - & - & - & - \\
\hline L. sp. & $23 b$ & - & - & - & 1 & - \\
\hline \multicolumn{7}{|l|}{ NOTOMMATIDAE } \\
\hline Cephalodella apocolea Myers, 1924 & 21a, 31b & 1 & 1 & - & - & - \\
\hline C. auriculata (Müller, 1773)* & $1,3,8,12,13,15,16,20$ & 4 & - & 5 & - & - \\
\hline C. catellina (Müller, 1786)* & 36 & - & - & - & - & + \\
\hline C. delicata Wulfert, 1937 & $1,6 a, 8,15,27,29 a, b$ & 1 & - & 3 & 3 & - \\
\hline C. cf. dentata Wulfert, 1937 & $3,6 \mathrm{~b}, 7,8,10,15,29 \mathrm{a}, \mathrm{b}$ & 1 & - & 5 & 2 & - \\
\hline
\end{tabular}


Table 2. Continued.

\begin{tabular}{|c|c|}
\hline & Localities or areas \\
\hline C. derbyi (Dixon-Nuttall, 1903) & 1 \\
\hline C. eva (Gosse, 1887)* & $\mathrm{B}$ \\
\hline C. exigua (Gosse, 1886$)^{*}$ & $\mathrm{~B}$ \\
\hline C. forficata (Ehrenberg, 1832) & $6 \mathrm{a}, 8,9,12,15,23 \mathrm{a}$ \\
\hline C. gibba (Ehrenberg, 1832) & $1,6 b, 7,12,18 a, 29 a, b, 36,38$ \\
\hline C. glandulosa Koch-Althaus, 1962 & 22 \\
\hline C. globata (Gosse, 1887) & $\mathrm{B}$ \\
\hline C. gracilis (Ehrenberg, 1832) & 36,38 \\
\hline C. harringi Smirnov, 1927 & 15 \\
\hline C. hoodi (Gosse, 1886$)^{*}$ & $\mathrm{~B}$ \\
\hline C. intuta Myers, 1924 & $11,15,17,25,36$ \\
\hline C. limosa Wulfert, 1937 & $\mathrm{~B}$ \\
\hline C. megalocephala (Glascott, 1893)* & 3,38 \\
\hline C. nana Myers, 1924 & 15 \\
\hline C. pachydactyla Wulfert, 1937 & 25,36 \\
\hline C. sterea Donner, 1950 & 25 \\
\hline C. tantilloides Hauer, 1935 & $6 a, 7,13,16,18 a, b, 26$ \\
\hline C. theodora Koch-Althaus, 1961 & $8,11,14,29 a$ \\
\hline C. ventripes (Dixon-Nuttall, 1901) & $2,6 a, b, 8,9,10,12,15,19 a, 23 c, 29 b$ \\
\hline C. wrighti Wulfert, 1960 & $\mathrm{~B}$ \\
\hline C. sp. & 3 \\
\hline Monommata cf. actices Myers, 1930 & $6 b$ \\
\hline M. dentata Wulfert, 1940 & $3,15,26$ \\
\hline M. grandis Tessin, 1890 & 1,13 \\
\hline M. cf. phoxa Myers, 1930 & 1 \\
\hline Notommata allantois Wulfert, 1935 & 36 \\
\hline N. cyrtopus (Gosse, 1886) & 36 \\
\hline N. falcinella Harring \& Myers, 1921 & 5 \\
\hline N. lenis Harring \& Myers, 1922 & $2,3,6 b, 8,15$ \\
\hline N. placida Harring \& Myers, 1924 & $7,18 \mathrm{a}$ \\
\hline N. tripus Ehrenberg, 1838 & $29 b$ \\
\hline Resticula nyssa Harring \& Myers, 1924 & 14,26 \\
\hline Taphrocampa annulosa Gosse, 1851 & $1,3,20,29 b, 31 b$ \\
\hline T. selenura Gosse, 1887 & $\mathrm{~B}$ \\
\hline
\end{tabular}

I II III IV V

TRICHOCERCIDAE

Trichocerca bidens (Lucks, 1912)

T. brachyura (Gosse, 1851)

$6 a$

36

$6 b, 36$

T. cavia (Gosse, 1886)

T. cf. collaris (Rousselet, 1886)

$18 \mathrm{~b}$

T. cylindrica (Imhof, 1891)

T. gracilis (Tessin, 1890)

$18 \mathrm{a}$

$18 \mathrm{~b}$

T. longiseta (Schrank, 1802)

T. longistyla (Olofsson, 1918)

7, 13, 29a, b

B

T. lophoessa (Gosse, 1886)

2, $6 \mathrm{a}, 15,30 \mathrm{~b}, 36$

T. maior (Hauer, 1936)

T. cf. musculus (Hauer, 1936)

T. obtusidens (Olofsson, 1918)

T. parvula (Carlin, 1939)

T. porcellus (Gosse, 1851)

B

3

1, 3, 4, 7, 11, 15, 18b, 27, 30b, 36

B

$13,29 \mathrm{~b}, 30 \mathrm{~b}$

36 
Table 2. Continued.

\begin{tabular}{|c|c|c|c|c|c|c|}
\hline & Localities or areas & I & II & III & IV & $\mathrm{V}$ \\
\hline T. rattus (Müller, 1776) & 36 & - & - & - & - & + \\
\hline T. cf. rosea (Stenroos, 1898) & 7 & 1 & - & - & - & - \\
\hline \multicolumn{7}{|l|}{ T. scipio (Gosse, 1886)B } \\
\hline T. cf. siamensis Segers \& Polpunthin, 1997 & $23 \mathrm{a}$ & - & - & - & 1 & - \\
\hline T. tenuior (Gosse, 1886$)^{*}$ & $\mathrm{~B}$ & - & - & - & - & - \\
\hline T. tigris (Müller, 1786) & $3,7,30 \mathrm{~b}$ & 1 & - & 1 & 1 & - \\
\hline T. sp. 1 (cf. T.mollis (Edmondson, 1936)) & $1,18 \mathrm{a}$ & 2 & - & - & - & - \\
\hline T. sp. 2 & 36 & - & - & - & - & + \\
\hline
\end{tabular}

\section{GASTOPODIDAE}

Ascomorpha agilis Zacharias, $1893 \quad$ B

Gastropus minor (Rousselet, 1892)* 26, 29a, b, 30b

\section{SYNCHETIDAE}

Polyarthra longiremis Carlin, $1943 \quad 35$

P. minor Voigt, 1904*

$1,5,7,13,18 \mathrm{a}, \mathrm{b}$

P. remata (Skorikov, 1896)*

P. vulgaris Carlin, 1943

Synchaeta pectinata Ehrenberg, 1832

$23 \mathrm{a}, \mathrm{b}, \mathrm{c}$

$4,21 b, c, 34 b$

$23 \mathrm{~b}, \mathrm{c}, 35$

S. tremula (Müller, 1786)

2, 23a, b, c

\section{DICRANOPHORIDAE}

Dicranophorus luetkeni (Bergendal, 1892)* $\quad$ B, H

D. rostratus (Dixon-Nuttall \& Freeman, 1902) 29a

Encentrum arvicola Wulfert, $1936 \quad 25$

E. glaucum Wulfert, 1936 B

E. mustela (Milne, 1885)

E. putorius Wulfert, 1936

Erignatha clastopis (Gosse, 1886)* 15

Paradicranophorus hudsoni (Glascott, 1893) $\quad \mathrm{H}$

\section{MICROCODONIDAE}

Microcodon clavus Ehrenberg, $1830 \quad 1,3,13,18 \mathrm{a}$

TESTUDINELLIDAE

T. aspis Carlin, 1939

Testudinella incisa (Ternetz, 1892)

T. patina (Hermann, 1783)

\section{$\mathrm{H}$}

$18 \mathrm{a}$

36

\section{CONOCHILIDAE}

Conochilus hippocrepis (Schrank, 1830)

$4,19 \mathrm{~b}, \mathrm{c}, 23 \mathrm{c}, 33$

C. unicornis Rousselet, 1892

$12,19 \mathrm{~b}, \mathrm{c}, 23 \mathrm{c}, 33$ 
Table 3. Distribution of species in the habitat categories at the localities surveyed.

\begin{tabular}{lcccc}
\hline Category & I & II & III & IV \\
\hline Number of localities & 10 & 11 & 13 & 12 \\
Number of samples taken & 10 & 11 & 20 & 14 \\
Species found & 43 & 22 & 50 & 46 \\
Species found only here & 16 & 6 & 16 & 14 \\
Maximum species in a sample & 17 & 7 & 15 & 17 \\
Minimum species in a sample & 4 & 2 & 1 & 1 \\
Mean number per sample & 10.5 & 4.4 & 7.3 & 6.7 \\
Species found only once & 9 & 4 & 17 & 8 \\
Species with abundance 2 and 3 & 4 & 2 & 17 & 19 \\
Samples with abundance 2 and 3 & 5 & 3 & 7 & 9
\end{tabular}

Loc. $\mathbf{6 b}$ - a nearby, narrow, flooded ditch in a meadow $-\mathrm{pH}$ 5.5:

Microcodides chlaena (3), Microcodides sp. (2), Euchlanis dilatata, Proalinopsis caudata, Cephalodella gibba, C. ventripes $(3, \mathrm{~m})$, Monommata cf. actices (2), Notommata lenis (2, r. e.), Trichocerca cavia, Synchaeta sp.

Only the abundant Cephalodella ventripes was at both localities. The other species seemed to be confined to the one locality.

\section{Neighbouring localities, river area in Teigdalen}

Loc. 29a - a bend with a grassy shore and clay and mud on the bottom, nearly separated from the river at Sevaldstad - $\mathrm{pH}$ 6.0: Notholca squamula (2), Euchlanis alata, Cephalodella delicata, C. cf. dentata, C. gibba, C. theodora, Notommata. sp., Taphrocampa annulosa, Gastropus minor, Trichocerca longiseta (3), Dicranophorus rostratus

Loc. 29b - a ditch very close by, with rich aquatic and shore vegetation, also nearly separated from the river $-\mathrm{pH} 6.0$ :

Notholca squamula, Euchlanis alata, Lepadella acuminata, L. patella, Proales cf. decipiens, Cephalodella delicata (2), C. cf. dentata, C. gibba, C. ventripes (2), C. sp., Monommata sp., Notommata tripus, N. sp., Taphrocampa annulosa, Trichocerca longiseta, T. porcellus, Gastropus minor

Here, as many as nine species were common to both localities, three of them with a higher abundance level at one of the localities. Eight species were found only in the more varied 29b, and only two in 29a. These were the two most closely situated localities.

\section{Tarns in Eksingedalen}

Loc. 12 - tarn 1 in rocky forest above the river at Bergo - pH 5.25:

Trichotria tetractis caudata, Lecane lunaris, L. stichaea, Proales fallaciosa, Cephalodella auriculata, C. forficata, C. gibba (giant form), C. ventripes, Conochilus unicornis

Loc. 13 - tarn 2 above tarn 1, with outlet to it - pH 5.5:

Keratella serrulata, Euchlanis dilatata, E. triquetra, Trichotria truncata, Lepadella acuminata, Lecane lunaris, Cephalodella auriculata, C. tantilloides, Monommata grandis, Trichocerca longiseta, T. porcellus, Polyarthra minor, Microcodon clavus (2)

Only two species were common to both tarns, despite the outlet from 2 to 1

Loc. 18a - a large tarn on the mountain near Grøndalsvatn $-\mathrm{pH}$ 5.0:

Trichotria sp., Lepadella rottenburgi, L. sp., Lecane lunaris, L. perplexa, Cephalodella gibba, C. tantilloides, Notommata placida, Trichcerca cylindrica, T. sp. 1, Polyarthra minor, Testudinella incisa, Microcodon clavus, Conochilus sp.

Loc. 18b - a small tarn just above 18a - pH 5.25:

Colurella tessellata, Lepadella rottenburgi, Lecane lunaris, $L$. constricta, L. stichaea, Cephalodella tantilloides, Trichocerca cf. collaris, T. gracilis, T. obtusidens, Polyarthra minor, Ptygura sp.

Four species were common to both tarns. Water can probably flow from the highest tarn when ice and snow are melting.

\section{Different dates, almost the same site in the river area in Eksingedalen}

Loc. 3 - Flatekval, shallow water on a river bend in a meadow $-\mathrm{pH}$ 5.5-6.0:

13/6 - after a sunny period: Trichotria tetractis caudata, Cephalodella cf. dentata, C. ventripes (2), C. sp. (the strange one), Notommata lenis, Trichocerca obtusidens (2)

16/6 - after heavy rain (sample higher up on the shore): Euchlanis triquetra, Trichotria tetractis caudata, Cephalodella ventripes, Trichocerca cf. musculus, Microcodon clavus

Only two species were recorded on both dates; one of them was the abundant $C$. ventripes.

10/7 - also flooded: Euchlanis triquetra (2), Lepadella acumonata, Lecane perplexa, Cephalodella auriculata, Taphrocampa annulosa, Trichicerca tigris

Only one of the foregoing species was seen on this occasion.

8/8 - meadow drier (sample lower on the shore): Only Cephalodella megalocephala was found, and this was the only occasion it was found.

Loc. 15 - Nesheimsvatn, vegetation-rich bay in a lake-like stretch of river $-\mathrm{pH}$ 6.0-6.25:

3/7-meadow flooded: Euchlanis dilatata, E. triquetra, Trichotria tetractis caudata, Proalinopsis caudata, Cephalodella auriculata (2), C. delicata, C. cf. dentata, C. harringi, C. forficata, C. ventripes (2), Notommata lenis, Trichocerca lophoessa, $T$. obtusidens, Synchaeta sp., Erignatha clastopis

7/8 - meadow drier (sample lower): Lepadella patella, Monommata dentata, Cephalodella auriculata, C. delicata, C. tantilloides, C. ventripes, Notommata sp., Trichocerca obtusidens, Erignata clastopis.

Only three of the many species were found on the second date, the abundant $C$. ventripes, the rather common $T$. obtusidens, and E. clastopis which was only found at this locality. Six other species were found, however. 
A great disparity in species composition was seen, even between neighbouring and connected localities sampled on the same date. Relatively slow currents or the movement of the rotifers themselves apparently did not distribute the species more evenly along the vegetation-rich shores of lake-like stretches of river or associated pools. However, a new sampling at almost identical sites after a significant rise in the water level causing more rapid flow, showed large differences in the species composition. Most species were probably removed from a site by the moving water, and others were taken to it. A number of species might disappear when the water level sank. When habitats are drying out, many species produce resting eggs before vanishing.

\section{Abundance, diversity and frequency}

Most species were most abundant at the lowest level. The following occurred at levels 2 and 3 (more than one observation is shown in brackets): Notholca labis, N. squamula, Euchanis alata (3x), E. dilatata, E. lyra, E. triquetra (2x), Colurella tessellata, Proales decipiens, Cephalodella auriculata, C. delicata, C. tantilloides, C. ventripes (7x), Monommata $\mathrm{cf}$. phoxa, Notommata falcinella, N. lenis, Trichocerca longiseta, T. obtusidens (2x), T. porcellus, T. tigris, Synchaeta pectinata, S. tremula, S. sp. (2x), Polyarthra remata (3x), P. vulgaris, Erignatha clastopis, Microcodon clavus (2x) and Conochilus unicornis. Altogether 27 species were sometimes abundant, about $1 / 4$ of the total number found; 20 of them were abundant only once, four twice, two three times, and the very common Cephalodella ventripes as many as seven times, with males seen on three occasions.

Most records of relatively high rotifer abundance were from shallow, lake-like stretches of river which were rich in vegetation and had many different micro-habitats, with plenty of food and shelter. The $\mathrm{pH}$ varied between 5.5 and 7.5. The highest values might be due to farm waste, manure, or high photosynthesis of the rich vegetation, all indicating some degree of eutrophy. Even one of the species in the three low-lying, vegetation-rich small lakes and the two small bog pools with $\mathrm{pH}$ 5.0-5.5 had a higher abundance level. Both the abundance and the species diversity could be quite high at several localities in these vegetation-rich areas.

May \& O'Hare (2005), who collected rotifers along a trophic gradient in Loch Lomond, Scotland, concluded that abundance, not species composition, was the most sensitive indicator of eutrophy. The more oligotrophic looking localities in the mountains, with barren surroundings and $\mathrm{pH}$ 5.0-5.5, had no species with an abundance level higher than 1 . However, the three tarns with some grass, sedges and mosses along their shallow shores, had rather high species diversities. Myers (1931) pointed out the high rotifer diversity, with a low abundance of each species, in acid, mineral-poor habitats with Sphagnum and/or other vegetation on the shores. The opposite was seen in alkaline habitats.
For most of the species collected, the frequency of records was very low. Of the 100 different rotifers identified, only 17 were collected at 6 to 11 localities. The most frequently recorded species was the most abundant Cephalodella ventripes found in 15 samples at 11 localities. The others, in a systematic order (localities-samples), are: Kellicottia longispina 6-7, Keratella hiemalis 7-7, Euchanis dilatata 9-10, Euchlanis triquetra 10-102. Trichotria tetractis caudata 6-6, Lepadella acuminata 6-6, Lepadella patella 6-7, Lecane lunaris 11-11, L. stichaea 7-7, Cephalodella auriculata 8-9, C. delicata 7-7, C. cf. dentata 8-8, C. gibba 7-7, C. tantilloides 7-7, Trichocerca obtusidens 10-10, Polyarthra minor 6-6.

Four species were found only twice, as a single specimen or in a small number, but at very distant localities: Euchlanis oroha, Mytilina videns, Cephalodella apocolea, Resticula nyssa. 37 species were found only in a single sample, as a single specimen or in a small number, except for Notholca labis which had abundance level 2.

A similar distribution pattern has been recorded from flood plains and other areas with many enclosed water bodies in other parts of the world. Shiel \& Koste (1983) recorded a remarkable disparity in species composition in the species-rich habitats of ephemeral pools and billabongs along flood plains in northern and eastern Australia. Furthermore, Koste \& Shiel (1986) reported that as many as $81 \%$ of the 63 newly recorded species were found in only one or two of the many, mostly acid, habitats investigated in Tasmania. A restricted distribution of most species was also recorded from Tasmania later (Koste \& Shiel 1987).

\section{FRESHWATER ROTIFERS PREVIOUSLY COLLECTED IN NORWAY}

The 200 species previously found in Norway are in Table 4, with synonyms or other names used. The counties in which the species were collected and the authors who recorded them are listed in chronological order (except the most commonly recorded planktonic and semi-planktonic species). Figure 25 shows the counties.

\section{CONCLUDING REMARKS}

This survey of rotifers recorded in a relatively large area during a short summer season, with the material being examined fresh, certainly does not give a complete and detailed picture of the species diversity and distribution. It is more like a "snapshot" from a journey through the valleys. More samples from more localities, and from different dates and years, would probably have resulted in a considerably longer species list and even 
Table 4. Freshwater rotifers previously found in Norway, mostly with recording authors and the counties where they are found. Author abbreviations (alphabetic): B - Berzins, E - Elgmork, Ha - Halvorsen et al., H. - Hauge, H-K - Huitfelt-Kaas, K - Koksvik, L - Larsson, L-P - Lie-Pettersen, Lø - Løvik, O - Olofsson, R - Reinertsen et al, S - Strøm, T - Thomasson, V - Varga, W \& N -Wærvågen \& Nilssen. Counties investigated: F - Finnmark, T - Troms, N - Nordland, NT - Nord-Trøndelag, ST - Sør-Trøndelag, S - Sogn og Fjordane, H - Hordaland, R - Rogaland, VA - Vest-Agder, AA - Aust-Agder, Te - Telemark, B - Buskerud, O - Oppland, He - Hedmark, A - Akershus.

Species list with other names used by some of the recording authors, added in parenthesis behind the valid name. Recording authors listed in a chrono logical order. (Not for the most common species recorded.)

\begin{tabular}{lll}
\hline Species list & Counties & Recording authors \\
\hline HABROTROCHIDAE & & \\
Habrotrocha bidens (Gosse, 1851) & F, T, N, H & L-P, 1909, -10, V 1936a, -38
\end{tabular}

\section{PHILODINIDAE}

Dissotrocha aculeata (Ehrenberg, 1832)

D. macrostyla (Ehrenberg,1832)

Embata parasitica (Giglioli,1863) (Callidina parasitica)

Mniobia symbiontica (Zelinka, 1886) (Callidina symbiontica)

Philodina citrina Ehrenberg, 1832

P. megalotrocha Ehrenberg, 1832

P. roseola Ehrenberg, 1832

Pleurethra brycei (Weber, 1898)

Rotaria citrina (Ehrenberg, 1838) (Rotifer citrinus)

R. macroceros (Gosse, 1951) (R. macroceros)

R. macrura (Schrank, 1783) (R. macrurus)

R. rotatoria (Pallas,1766) (Rotifer vulgaris)

R. socialis (Kellicott, 1888) (Callidina socialis)

R. tardigrada (Ehrenberg, 1832) (Rotifer tardus)

\section{ADINETIDAE}

Adieta vaga (Davis, 1873)

\section{EPIPHANIDAE}

Epiphanes senta (Müller, 1773) (Hydatinia senta)

Microcodides chlaena(Gosse, 1886)

M. robustus (Glascott, 1892)

\section{BRACHIONIDAE}

Anuraeopsis fissa(Gosse,1851)

Notholca foliacea (Ehrenberg, 1838)

Brachionus angularis Gosse, 1851

B. calyciflorus Pallas, 1776

B. urceolaris Müller, 1773

Kellicottia longispina (Kellicott, 1879) (Notholca longispina)

Keratella cochlearis (Gosse, 1851) (Anuraea cochlearis)

K. hiemalis Carlin1943

K. quadrata quadrata (Müller, 1786) (A. aculeata, Ehrenberg, 1833)

K. q. dispersa Carlin, 1943

K. serrulata (Ehrenberg, 1838) (A. serrulata)

K. ticinensis (Caleiro, 1920)
F, T, N, H

L-P 1909, -10, V 1936a

$\begin{array}{ll}\text { F, H, O } & \text { L-P 1909, V 1938, Lø } \\ \text { F, T } & \text { L-P 1910, V 1938 } \\ \text { F } & \text { L-P 1909 } \\ \text { T, H } & \text { L-P 1909, -10 } \\ \text { F, T, N, H } & \text { L-P 1905, -09, -10, V 1938 } \\ \text { F } & \text { V 1936a } \\ \text { F, T, N, H } & \text { L-P 1909, -10, V 1936b, -38 } \\ \text { F, O } & \text { V 1936b, Lø } \\ \text { F, H } & \text { L-P 1909, V 1938 } \\ \text { T, H } & \text { L-P 1909 } \\ \text { F, T, N, H } & \text { L-P 1909, -10, V 1938 } \\ \text { F, T, N, H } & \text { L-P 1905, -09, -10, V 1936a, -38 } \\ \text { H } & \text { L-P 1909 } \\ \text { F, T, N, H } & \text { L-P 1909, -10 }\end{array}$

$\begin{array}{ll}\text { N } & \text { L-P } 1909 \\ \text { F } & \text { L-P } 1909 \\ \text { H } & \text { L-P } 1909\end{array}$

F

F L-P 1909 O

F, O V 1936a, S 1944

N-T R

F, N-T, H, He L-P 1905, -09, K, R

Common species

Common species

S-T, S, O B B, T, L 1978, Lø

Common species

S-T

$\mathrm{T}$

Common species

$\mathrm{AA} / \mathrm{Te}$ 
Table 4. Continued.

Species list

K. valga (Ehrenberg, 1834) (A. aculeata var. valga Ehrenberg)

Notholca acuminata (Ehrenberg, 1832) (N. labis, Gosse (L-P 1905),

N. striata var. labis (L-P, 1909))

N. labis Gosse, 1887

N. squamula (Müller, 1786) (N. striata Müller, N. striata var. jugosa Gosse)

Platyias quadricornis (Ehrenberg, 1832) (Noteus quadricornis)

\section{EUCLANIDAE}

Diplois daviesiae Gosse, 1886

Euchanis deflexa Gosse, 1851

E. dilatata Ehrenberg, 1832 (E. macrura)

E. oropha Gosse, 1887( E. parva)

E. pyriformis Gosse, 1851

E. triquetra Ehrenberg,1838 (E. pellucida Harring)

\section{MYTILINIDAE}

Lophocaris oxysternon (Gosse, 1851) (Metopidia oxysternon)

Mytilina bisulcata (Lucks, 1912) (Diplax bisulcata)

M. compressa (Gosse, 1851)

M. mucronata (Müller, 1773) (Salpinia mucronata, S. sulcata)

M. trigona (Gosse,1851) (Diplax trigona)

M. ventralis brevispina(Ehrenberg, 1832) (Salpina brevispina)

M. videns (Levander, 1894) (Diplax videns)

Macrochaetus subquadratus (Perty,1850) (Ploychaetus subquadratus)

\section{TRICHOTRIDAE}

Trichotria pocillum (Müller, 1776) (Dinocharis pocillum)

T. tetractis (Ehrenberg, 1830) (D. tetraactis)

T. truncata (Whitelegge,1889) (D. intermedia Bergendal)

\section{COLURELLIDAE/LEPADELLIDAE}

Colurella adriatica Ehrenberg, 1831 (Colurus caudatus Ehrenberg, 1838, Colurus leptus Gosse, 1887

C. colurus colurus (Ehrenberg, 1830) (Colurella colurus)

C. c. compressa (Lucks, 1912) (C. compressa)

C. obtusa (Gosse, 1886)

C. sulcata (Stenroos, 1898)

C. uncinata uncinata (Müller, 1773) (C. uncinata)

C. u. f. bicuspidata (Ehrenberg,1832) (Colurus bicuspidatus)

C. u. f. deflexa (Ehrenberg, 1834) (C. deflexus)

Lepadella acuminata (Ehrenberg, 1832) (Metopidia acuminata)

L. cristata (Rousselet, 1893)

L. ehrenbergi (Perty, 1850) (Metopidia ehrenbergi)

L. imbricata Harring, 1914

L. patella patella (Müller, 1786) (M. lepadella, M. oblonga (L-P -10))

L. p. oblonga (Ehrenberg, 1834) (L. oblonga)
F, T, H

Common species Common species

F, T, N, H

$\mathrm{F}$

F, T, N, H

F, S-T

F, T, S-T, H, O

$\mathrm{F}$

-P 1909, -10, O, T, L

L-P 1909

L-P 1909, -10, V

L-P 1909, -10. V 1936a, 1938

L-P 1909

L-P 1909, -10, O, V 1936a, -38

L-P 1909

V 1938

V 1938

L-P 1909

L-P 1909

L-P 1909, -10, V 1936a

V 1938

L-P 1909

F, O

F, N, H

$\mathrm{H}$

L-P 1909, O, V 1936a. Lø

L-P 1909, V 1938

L-P 1909

$\begin{array}{ll}\text { F, T, N, H } & \text { L-P 1905, -09,-10 } \\ \text { F, O } & \text { V 1938, L 1978 } \\ \text { F } & \text { V 1936a } \\ \text { F, H } & \text { L-P 1909, V 1938 } \\ \text { F } & \text { V 1938 } \\ \text { F } & \text { V 1936a, -38 } \\ \text { F, T, N, H } & \text { L-P 1905, -09. -10 } \\ \text { F, H } & \text { L-P 1909, V 1938 } \\ \text { F, T, N, S, H, O } & \text { L-P 1909, -10, O, V 1936a, B, L 1978 } \\ \text { F } & \text { V 1936a } \\ \text { F, H } & \text { L-P, 1909, V 1938 } \\ \text { O } & \text { L 1978 } \\ \text { F, T, N, H } & \text { L-P 1909, -10, V 1938 } \\ \text { F } & \text { V 1936a, 1938 }\end{array}$


Table 4. Continued.

\begin{tabular}{lll}
\hline Species list & Counties & Recording authors \\
\hline L. ovalis (Müller, 1786) (M. solidus, Gosse) & F, T, N, H, O & L-P 1909, -10, V 1936a, L 1978 \\
L. quadricarinata (Stenroos, 1898) (M. quadricarinata) & F & O \\
L. rhomboides (Gosse, 1886) (M. rhomboides) & F, H & L-P 1909, V 1938 \\
L. triptera (Ehrenberg, 1838) (M. triptera) & F, T, N, H & L-P 1909, -10, V 1838 \\
Squatinella longispinata (Tatem, 1867) (Stephanops longispinatus) & F, T, N, H & L-P 1909, -10 \\
S. mutica (Ehrenberg,1846) (S. muticus) & F & L-P 1909 \\
S. rostrum (Schmarda, 1846) (S. lamellaris Müller) & H & L-P 1909
\end{tabular}

\section{LECANIDAE}

Lecane bulla (Gosse,1851) (Monostyla bulla)

F, N, T, H, S H-K, L-P 1909, V 1936a, -36b, -38

L. closterocerca (Schmarda, 1859) (Monostyla cornuta Ehrenberg (L-P 1909) M. closterocerca)

F, H

F

F, T, H

$\mathrm{F}$

O

$\begin{array}{ll}\text { F, ST } & \text { O, T } \\ \text { H } & \text { L-P 1909 } \\ \text { F, H } & \text { L-P 1909, V } 1938\end{array}$

Common species

Common species

$\mathrm{F}$

F

V 1938

V 1938

$\begin{array}{ll}\text { F } & \text { V } 1938 \\ \text { F } & \text { V } 1938\end{array}$

O L 1978

F, T, N, H L-P 1909, -10

H L-P 1909

Lindia truncata (Jennings, 1894) (Notommata truncata)
L-P 1909, -10, V 1938

$\mathrm{V} 1936 \mathrm{a},-36 \mathrm{~b}$

V 1938

V 1936a, -38

L-P 1909, -10, V 1936a, -38

L-P 1909, -10, V 1936a, -38

L-P 1909, -10, O, V 1936a

L-P 1909, -10, V 1936a

$\mathrm{V} 1936 \mathrm{a},-38$

V 1936a, -38

L-P 1909, -10 
Table 4. Continued.

\begin{tabular}{|c|c|c|}
\hline Species list & Counties & Recording authors \\
\hline Eosphora ehrenbergi,Weber, 1918 (Notommata najas Ehrenberg) & $\mathrm{F}, \mathrm{N}, \mathrm{H}$ & L-P 1909 \\
\hline E. najas Ehrenberg, 1830 (Euspora najas, E. digitata) & $\mathrm{F}, \mathrm{T}, \mathrm{H}$ & L-P 1909, -10 \\
\hline Itura aurita (Ehrenberg, 1830) & $\mathrm{F}$ & V 1938 \\
\hline I. viridis (Stenroos, 1898) & $\mathrm{F}$ & V 1938 \\
\hline Monommata grandis Tessin, 1890 (Furcularia grandis) & $\mathrm{F}, \mathrm{T}, \mathrm{H}$ & L-P 1909, -10, V 1938 \\
\hline M. longiseta (Müller, 1786) $(F$. longiseta) & $\mathrm{F}, \mathrm{T}, \mathrm{N}, \mathrm{H}$ & L-P 1909, -10, V 1936a, -38 \\
\hline Notommata aurita (Müller, 1786) & F, N, H & L-P 1909 \\
\hline N. brachyota (Ehrenberg, 1832) & $\mathrm{T}, \mathrm{H}$ & L-P 1909, -10 \\
\hline N. cerberus (Gosse,1886) (Copeus cerberus) & $\mathrm{F}, \mathrm{T}, \mathrm{N}, \mathrm{H}$ & L-P 1909, -10 \\
\hline N. collaris Ehrenberg, 1886 & $\mathrm{H}$ & L-P 1909 \\
\hline N. cyrtopus Gosse, 1886 & $\mathrm{H}$ & L-P 1909 \\
\hline N. pachyura (Gosse, 1886) (Copeus pachyurus) & $\mathrm{F}, \mathrm{N}, \mathrm{H}$ & L-p 1909, V 1938 \\
\hline N. pseudocerberus De Beauchamp, 1907 & $\mathrm{~F}$ & V 1938 \\
\hline N. saccigera Ehrenberg, 1832 & $\mathrm{~F}, \mathrm{H}$ & L-P 1909, V 1936a, -38 \\
\hline N. tripus Ehrenberg, 1838 (N. pilarius Gosse) & $\mathrm{F}, \mathrm{T}, \mathrm{N}, \mathrm{H}$ & L-P 1909, -10 \\
\hline Pleurotrocha petromyzon Ehrenberg, 1830 (Proales petromyzon) & $\mathrm{F}, \mathrm{N}, \mathrm{H}$ & L-P 1909, V 1938 \\
\hline Scaridium longicaudum (Müller, 1786) & F, T, N, H & L-P 1909, -10, V 1938 \\
\hline Taphrocampa annulosa Gosse, 1851 & $\mathrm{~F}, \mathrm{~T}, \mathrm{~N}, \mathrm{H}$ & L-P 1909, -10 \\
\hline \multicolumn{3}{|l|}{ TRICHOCERCIDAE } \\
\hline Elosa worallii Lord, 1891 & $\mathrm{~F}, \mathrm{H}$ & L-P 1909, V 1938 \\
\hline T. brachyura (Gosse, 1851) (Diurella brachyurus) & $\mathrm{F}, \mathrm{N}, \mathrm{H}$ & L-P 1909, V 1938 \\
\hline \multicolumn{3}{|l|}{ T. capucina (Wierzejski \& Zacharias,1893) (Rattulus capucinus, } \\
\hline Mastigocerca capucina) & $\mathrm{F}, \mathrm{S}, \mathrm{O} / \mathrm{He}$ & H-K, L-P 1909, V 1938 \\
\hline T. cavia (Gosse, 1886) (Diurella cavia) & $\mathrm{F}, \mathrm{H}$ & L-P 1909, V 1938 \\
\hline T. collaris (Rousselet,1896) (D. collaris) & $\mathrm{F}, \mathrm{N}, \mathrm{H}$ & L-P 1909, V 1936a \\
\hline T. cylindrica (Imhof, 1891) & $\mathrm{H}$ & $\mathrm{H}$ \\
\hline T. elongata (Gosse, 1886) & $\mathrm{F}$ & V 1938 \\
\hline T. gracilis (Tessin,1890) (Rattulus gracilis) & $\mathrm{N}, \mathrm{H}$ & L-P 1909 \\
\hline T. longiseta (Schrank, 1802) (R. longiseta, Mastigoserca bicornis) & $\mathrm{F}, \mathrm{T}, \mathrm{N}, \mathrm{H}$ & H-K, L-P 1909, -10, O, V 1936a, -38 \\
\hline T. porcellus (Gosse, 1851) (Diurella porcellus, Coelopus porcellus) & F, T, N, H, R & H-K, L-P 1909, -10, O \\
\hline T. pusilla (Jennings, 1903) & $\mathrm{B}$ & S 1932 \\
\hline T. rattus (Müller, 1776) (Rattulus rattus, $R$. carinatus) & F, T, N, H & L-P 1909, -10, O, V 1936a, -38 \\
\hline T. scipio (Gosse, 1886) (R. scipio) & $\mathrm{H}$ & L-P 1909 \\
\hline T. sejunctipes (Gosse, 1886) (Diurella sejunctipes) & $\mathrm{H}$ & L-P 1909 \\
\hline T. tenuior (Gosse, 1886) (D. tenuior) & $\mathrm{F}$ & V 1936a \\
\hline T. tigris (Müller, 1786) (D. tigris) & $\mathrm{F}, \mathrm{T}, \mathrm{N}, \mathrm{H}$ & L-P 1909, O, V 1936a, -38 \\
\hline T. weberi (Jennings, 1903) & $\mathrm{F}$ & V 1936a, $-36 b,-38$ \\
\hline
\end{tabular}

\section{GASTROPODIDAE}

Ascomorpha ecaudis Perty, 1850 (Sacculus viridis Gosse)

A. ovalis (Bergendahl, 1892) (Anapus ovalis, A. testudo Lauterborn)

Common species

$\begin{array}{ll}\text { F, T, N, H } & \text { L.P 1909, -10 } \\ \text { F, T } & \text { L-P, 1910, V 1938 } \\ \text { F, T, H, AA/Te } & \text { L-P 1909, -10, W\&N }\end{array}$

Gastropus minor (Rousselet, 1892)

G. stylifer Imhof, 1891

F, T, H, AA/Te L-P 1909, -10, W\&N

\section{SYNCHAETIDAE}


Table 4. Continued.

\begin{tabular}{|c|}
\hline Species list \\
\hline
\end{tabular}

P.truncatum (Levander, 1894)

Polyarthra dolicoptera (Idelson, 1925)

P. major (Burckhardt, 1900)

P. minor Voigt, 1904

$P$. remata (Skorikov, 1896)

P. vulgaris Carlin, 1943 (P. trigla Ehrenberg, P. platyptera)

Synchaeta grandis Zacharias

S. kitina (Rousselet, 1902)

S. longipes Gosse, 1887

S. oblonga Ehrenberg, 1831

S. pectinata Ehrenberg, 1832

S. stylata Wierzejski, 1893

S. tremula (Müller, 1786) (S. truncata von Hofsten)

\section{ASPLANCHNIDAE}

Asplanchna brightwelli (Gosse, 1851)

A. herricki De Guerne, 1888

A. priodonta Gosse, 1850

Asplanchnopus multiceps (Schrank, 1793) (A. myrmeleon (Ehrenberg)
Counties

F, T, H, R

F, H, B

AA/Te, B

S, B

$\mathrm{F}, \mathrm{AA} / \mathrm{Te}$

AA/Te, B

Common species

F, B

O, A

F,B

$\mathrm{O} / \mathrm{He}$

Common species

B

Common species

H, O, He, A

B

Common species

$\mathrm{F}$

L-P 1909

$\begin{array}{ll}\text { H } & \text { L-P } 1909 \\ \text { F } & \text { V } 1938\end{array}$

$\begin{array}{ll}\text { F, T, N, H } & \text { L-P 1909, -10 } \\ \text { F } & \text { V } 1938 \\ \text { F, H } & \text { L-P } 1909 \\ \text { F } & \text { V } 1938 \\ \text { F, H } & \text { L-P 1909, V 1836a, -38 } \\ \text { F } & \text { V } 1938 \\ \text { F } & \text { V } 1938 \\ \text { F } & \text { V } 1938\end{array}$

F, T, N, H L-P 1909, -10

$\begin{array}{ll}\text { F } & \text { V } 1938 \\ \text { H } & \text { L-P 1909 } \\ \text { F, T, N, H, R } & \text { H-K, L-P 1905, -09, -10, V } 1938 \\ \text { F, T, N, H } & \text { L-P 1909, -10, V 1938 }\end{array}$

H-K, L-P 1909, -10, V 1936 a

L-P 1909, V 1936a, E

E, W\&N

V 1936a, W\&N

E, W\&N

L-P 1909, V 1936a, -38, E

L 1971, Lø

V 1938, H

$\mathrm{Ha}$

E

H-K, L-P 1909

E

P 1909

1938

\section{TESTUDINELLIDAE}

Testudinella incisa (Ternetz, 1892)

T. parva (Ternetz, 1892) (Pterodina bidentata)

T.patina (Hermann, 1783) (Pterodina patina)

T. reflexa (Gosse, 1887) (P. reflexa)
D. forcipatus (Müller, 1786) (Cercaria forcipata, Diglena forcipata

(Ehrenberg), D. grandis (Ehrenberg))

D. lütkeni (Bergendal, 1892)

Encentrum permolle (Gosse, 1886) (Diglena permollis)

E. saundersiae (Hudson, 1885)

Parencentrum lutetiae (Harring \&Myers, 1928)

P. plicatum (Eyferth, 1878)

MICROCODONIDAE

Microcodon clavus Ehrenberg, 1830

\section{FLOSCULARIIDAE}

Floscularia janus (Hudson, 1881) (Melicerta janus)

Ptygura brachiata (Hudson, 1886)

$\begin{array}{ll}\text { N, H } & \text { L-P } 1909 \\ \text { F } & \text { V } 1938 \\ \text { H } & \text { L-P } 1909\end{array}$


Table 4. Continued.

\begin{tabular}{|c|c|c|}
\hline Species list & Counties & Recording authors \\
\hline P. pilula (Cubitt, 1872) (O. pilula) & $\mathrm{H}$ & L-P 1909 \\
\hline P. rotifer (Stenroos, 1898) (O. rotifer) & $\mathrm{T}$ & L-P 1909 \\
\hline P. velata (Gosse, 1851) (O. velata) & $\mathrm{H}$ & L-P 1909 \\
\hline \multicolumn{3}{|l|}{ Sinantherina socialis (Linne, 1758) (Megalotrocha alboflavicans } \\
\hline Ehrenberg) & $\mathrm{T}$ & L-P 1910 \\
\hline \multicolumn{3}{|l|}{ CONOCHILIDAE } \\
\hline Conochilus dossuarius (Hudson 1875) & $\mathrm{F}, \mathrm{H}$ & L-P 1909, V 1938 \\
\hline C. hippocrepis (Schrank, 1830) (C. volvox Ehrenberg) & Common species & \\
\hline C. unicornis Rousselet, 1892 & Common species & \\
\hline \multicolumn{3}{|l|}{ HEXARTHRIDAE } \\
\hline Hexarthra mira (Hudson, 1871) & $\mathrm{AA} / \mathrm{Te}$ & $\mathrm{W} \& \mathrm{~N}$ \\
\hline \multicolumn{3}{|l|}{ FILINIDAE } \\
\hline Filinia longiseta (Ehrenberg, 1834) (Triarthra longiseta) & Common species & \\
\hline F. passa (Müller,1786) (T. mystacina Ehrenberg) & $\mathrm{H}$ & L-P 1909 \\
\hline F. terminalis (Plate, 1886) & $\mathrm{AA} / \mathrm{Te}, \mathrm{O}, \mathrm{A}$ & L 1971, Lø, W\&N \\
\hline \multicolumn{3}{|l|}{ COLLOTHECIDAE } \\
\hline C. ambigua (Hudson, 1883) (Floscularia ambigua, C.algicola) & $\mathrm{H}, \mathrm{F}$ & L-P 1909, V 1938 \\
\hline C. campanulata (Dobie, 1849) (C. longicaudata) & $\mathrm{H}, \mathrm{F}$ & L-P 1909, V-36b, -38 \\
\hline C. coronetta (Cubitt, 1868) (Floscularia coronetta) & $\mathrm{H}$ & L-P 1909 \\
\hline C. heptabranchiata (Schoch, 1869) & $\mathrm{F}$ & V 1938 \\
\hline C. libera (Zacharias, 1894) & $\mathrm{F}, \mathrm{O}, \mathrm{A}$ & V 1936b, L 1971, -78 \\
\hline C. mutabilis (Hudson, 1885) (F. mutabilis) & $\mathrm{F}, \mathrm{N}, \mathrm{H}, \mathrm{O}, \mathrm{He}, \mathrm{A}$ & L-P 1909, L 1971, -78, Нa \\
\hline C. ornata (Ehrenberg, 1832) (F. cornuta) & $\mathrm{F}, \mathrm{T}, \mathrm{N}, \mathrm{H}$ & L-P 1909, -10, V 1936b, -38 \\
\hline C. trilobata (Collins, 1872) (F. trilobata) & $\mathrm{H}$ & L-P 1909 \\
\hline Stephanoceros fimbriatus (Goldfuss, 1820) (S. eichhorni Ehrenberg) & $\mathrm{F}, \mathrm{H}$ & L-P 1909 \\
\hline
\end{tabular}

extended the distribution pattern in the area. Seasonal or interannual variations in the species composition could be observed. Walsh et al. (2007) assumed that a dramatic underestimation of the richness of species was possible when only single samples were taken or projects were short term.

The many shallow pools, bends and narrow streams investigated along the shores of lake-like, vegetation-rich, stretches of river have demonstrated the presence of a rich biodiversity. These habitats would be totally separated from the river and would dry out during longer periods without rain and flowing water. The many resting stages which accumulate at such times represent the "seed bank" of an area. They depend, however, on a high water level in the river if they are to hatch and continue life, and also require flowing water to spread to wider areas. Extensive river regulations, with changes in river-flow regimes, have a deleterious effect on flood-plain communities (Shiel et al. 1998).
Following the regulation in the areas described here, there is normally less water flowing in the rivers. However, during the spring thaw, and after heavy rain, the river areass still fill up a great deal. Thresholds were also constructed at the end of the shallow, lake-like stretches of river in Eksingedalen to keep more stable conditions for the fish. Nesheimsvatn, a lake with very varied fauna and flora, has been protected as a nature reserve. The water there is relatively stagnant, and sedges grow on its banks. The water flow in Teigdalen varies more, but a small threshold has been constructed below Mæstadvatn. The influence of the regulation on the number of habitats and the diversity of their microfauna does not seem to be very deleterious. However, a new investigation is required to confirm that. 


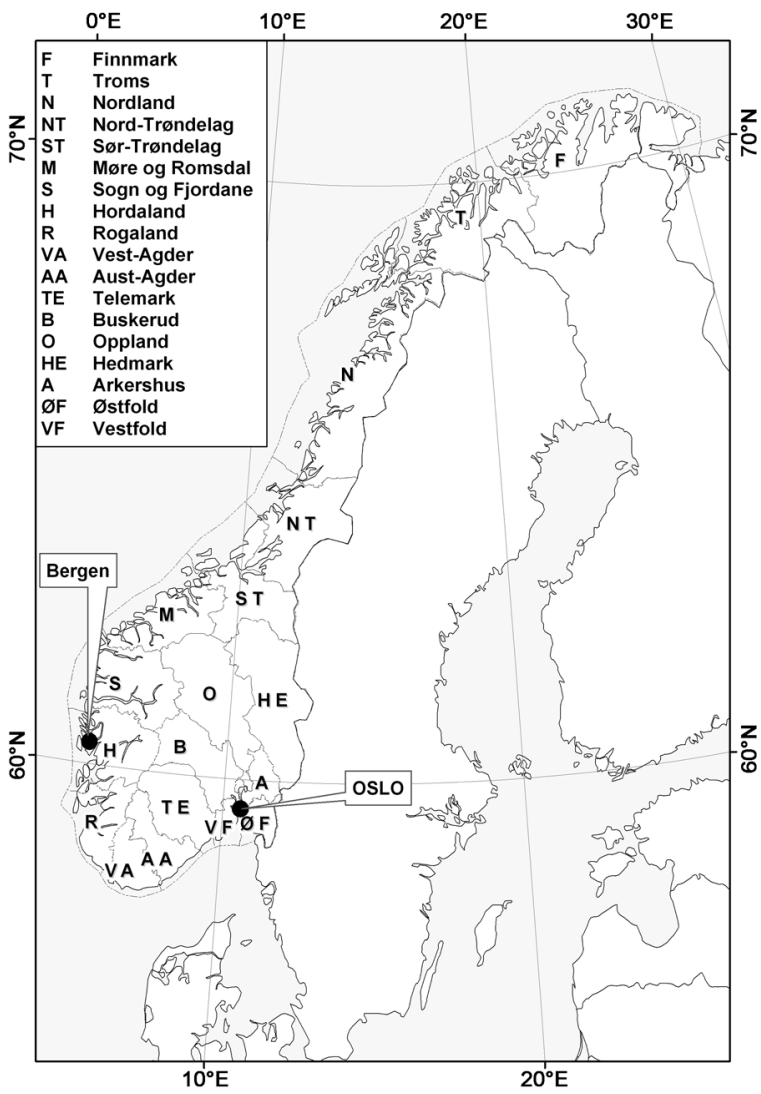

Figure 25. Map of Norway, showing the counties.

\section{ACKNOWLEDGEMENTS}

I wish to thank those who have encouraged me or given me advice and help in this comprehensive updating and writing process, especially Lita Greve Jensen, formerly senior curator at the Zoological Museum in Bergen, Kaare Aagaard, Torkild Bakken and Jan Ivar Koksvik, senior curators at the Museum of Natural History and Archaeology, Norwegian University of Science and Technology, Trondheim, senior academic librarian Hege Folkestad and senior librarian Asta Lunde Nord at the University Library in Bergen, Professor Per Gøran Krüger, zoologist and friend, and finally my son, Stig Godske Bjørklund, who has given me practical help with the computer.

\section{REFERENCES}

Berzins B. 1952. Contributions to the knowledge of the marine Rotatoria of Norway. Årbok for Universitetet i Bergen 1951, matematisk-naturvitenskapelig rekke 6: 1-11.

Berzins B, Pejler B. 1987. Rotifer occurrence in relation to $\mathrm{pH}$. Hydrobiologia 147: 107-116.

Berzins B, Pejler B. 1989. Rotifer occurrence in relation to trophic degree. Hydrobiologia 182(2): 171-180.

Bjørklund BG. 1972a. The rotifer fauna of rock-pools in the
Tvärminne archipelago, Southern Finland. Acta Zoologica Fennica 135: 1-30.

Bjørklund BG. 1972b. Taxonomic and ecological studies of Notholca (Rotatoria) found in sea and brackish water, with description of a new species. Sarsia 51: 25-66.

Bjørklund BG. 1996. Rotatoria Hjuldyr. In: Aagaard, K. and Dolmen, D. (eds). Limnofauna Norvegica. Tapir forlag. Pp. 58-69.

De Smet WH. 1988. Rotifers from Bjørnøya (Svalbard), with the description of Cephalodella evabrodei n. sp. and Synchaeta lakowitziana arctica n. subsp. Fauna Norvegica. Serie A 9: $1-18$.

De Smet WH. 1993. Report on rotifers from Barentsøya, Svalbard (78 30 N). Fauna Norvegica Serie A 14: 1-26.

De Smet WH. 1996. The Proalidae (Monogononta). In: Dumont HJF (ed). Guides to Identification of the Microinvertebrates of the Continental Waters of the World. SPB Academic Publishing bv 4. pp 102.

De Smet WH. 1997. The Dicranophoridae (Monogononta). In: Dumont HJF (ed). Guides to Identification of the Microinvertebrates of the Continental Waters of the World. SPB Academic Publishing bv 5. pp 318.

De Smet WH. 2001. Freshwater Rotifera from plankton of the Kerguelen Islands (Subantarctica). Hydrobiologia 446/447: 261272.

De Smet WH, Van Rompu EA, Beyens L. 1988. Contribution to the Rotifers and aquatic Tardigrada of Edgeøya (Svalbard). Fauna Norvegica. Serie A 9: 19-30.

Donner J. 1950. Radertiere der Gattung Cephalodella aus Sudmahren. Archiv für Hydrobiologie. 42: 304-328.

Dumont J, Coussement M. 1976. Rotifers from Rio Oro (NorthWestern Sahara). Hydrobiologia 51: 109-112.

Edmondson WT. 1936. New Rotatoria from New England and New Brunswick. Transactions of the American Microscopical Society 55 (2): 214-222.

Edmondson WT. 1948. Two new species of Rotatoria from sand beaches, with a note on Collotheca Wiszniewskii. Transactions of the American Microscopical Society 67: 149-152.

Elgmork K. 1964. Dynamics of zooplankton communities in some small inundated ponds. Folia limnologica scandinavica 12: $1-83$.

Eriksen BG. 1968. Marine rotifers found in Norway, with description of two new and one little known species. Sarsia 33: 23-34.

Eriksen BG. 1969. Rotifers from two tarns in southern Finland, with a description of a new species, and a list of rotifers previously found in Finland. Acta Zoologica Fennica 125: 1-36.

Halvorsen G, Dervo B, Papinska K. 2004. Zooplankton of Lake Atnsjøen 1995-1997. Hydrobiologia 515: 149-175.

Harring HK. 1913. Synopsis of the Rotatoria. Washington. pp 226.

Harring HK, Myers FJ. 1922. The rotifer fauna of Wisconsin. Trans. Wis. Acad. Sci. Arts. Lett. 20: 553-662.

Hauer J. 1935. Rotatorien aus dem Schluchsemoor und seiner Umgebung. Ein Beitrag zur Kenntnis der Rotatorienfauna der Schwarzwaldhochmoore. Verh. Naturw. Ver. Karlsruhe 29: 47-130.

Hauge HV. 1957. Vangsvatn and some other lakes near Voss. A limnological survey in western Norway. Folia limnologica scandinavica (9): 1-189. 
Hofsten N von. 1923. Rotatorien der Nordschwedischen Hochgebirge. Naturwissenschaftlische Untersuchungen der Sarekgebirge. 4(8): 829-894.

Huitfelt-Kaas H. 1906. Planktonundersøgelser i norske vande. Christiania. National trykkeriet. pp 199.

Jersabek CD. 2002. A case of considerable confusion in rotifer taxonomy: the Cephalodella crassipes complex. Arch. Hydrobiol. Suppl. 139/2, Monogr. Stud.: 265-274.

Koch-Althaus B. 1961. Cephalodella theodora n. sp., ein neues Rotator dem Stechlinsee. Zoologischer Anzeiger 166: 219-221.

Koch-Althaus B. 1962. Weitere neue und bemerkenswerte Rotarorien aus dem Stechlinsee. Limnologica 1: 65-82.

Koksvik JI. 1985. Ørretbestanden i Innerdalsvatnet, Tynset kommune, de tre første årene etter regulering. Kongelige norske Videnskabers Selskab Museet Rappoort Zoologisk Serie 1985,5: 1-35.

Koste W. 1978. Rotatoria. Die Rädertiere Mitteleuropas begründet von Max Voigt. Monogononta. Stuttgart. Gebrüder Borntraeger. I, 673 p, II, 234 pl.

Koste W, Shiel RL. 1986. New Rotifera (Aschelminthes) from Tasmania. Transactions of the Royal Society of South Australia 110 (3): 93-109.

Koste W, Shiek RL. 1987. Tasmanian rotifera: Affinities with the Australian Fauna. Hydrobiologia 147: 31-43.

Koste W, Shiel RL. 1992. Rotifera from Australian inland waters VII Trichocercidae. Transactions of the Royal Society of South Australia 116: 1-27.

Koste W, Janetzky W, Vareschi E. 1993. Zur Kenntnis der limnischen Rotatorienfauna Jamaikas (Rotatoria: Aschelminthes). Teil I. Osnabrücker naturwissenschaftliche Mitteilungen 19: 243-149.

Koste W, Terlutter H. 2001. Die Rotatorienfauna einiger Gewässer des Naturschutzgebietes "Heilige Meer" im Kreis Steinfurt. Osnabrücker Naturwissenschaftliche Mitteilungen 27: 113-127.

Larsson P. 1968. Vertical distribution of planktonic rotifers in a meromictic lake: Blankvatn near Oslo, Norway. Norwegian Journal of Zoology 19: 47-75.

Larsson P. 1978. The life cycle dynamics and production of zooplankton in øvre Heimdalsvatn. Holarctic Ecology 1: 162-218.

Lie-Pettersen OJ. 1905. Beitrage zur Kenntnis der marinen Rädertierfauna Norwegens. Bergens Museums Aarbog (10): $1-44$.

Lie-Pettersen OJ. 1909. Zur Kenntnis der Süsswasser-RädertierFauna Norwegens. Bergens Museums Aarbog (15): 1-100.

Lie-Pettersen OJ. 1910. Rotatoriefaunaen paa Tromsø. Tromsø Museums Aarshefte 33: 41-73.

Løvik JE. 1980. Dyreplankton i Randsfjorden. Fauna 33: 18-28.

Løvik JE. 1984. Dyreplanktonsuksesjon i Jarenvatnet, ein eutrof innsjø på Hadeland. Fauna 37: 26-33.

May L, O'Hare M. 2005. Changes in rotifer species composition and abundance along a trophic gradient in Loch Lomond, Scotland, UK. Hydrobiologia 546:397-404.

Myers F. 1930. The rotifer fauna of Wisconsin. V. The genera Euchlanis and Monommata. Trans. Wis. Acad. Sci Arts. Lett. 25: 353-413.

Myers F. 1931. The distribution of Rotifera on Mount Desert Island. American Museum Novitates (494): 1-12.

Nogrady T. 1980. Canadian Rotifers II. Parc Mont Tremblant, Quebec. Hydrobiologia 71: 35-46.
Nogrady T, Pourriot R. 1995. The Notommatidae. In: Dumont HJF (ed).Guides to identification of the Microinvertebrates of the Continental Waters of the World. SPB Academic Publishing bv 3. pp 229.

Olofsson O. 1917. Süsswasser-Entomostraken und Rotatorien vom der Murmanküste und aus dem nördlichsten Norwegen. Zoologiska Bidrag Uppsala 5: 259-294.

Olofsson O. 1918. Studien über die Süsswasserfauna Spitsbergens. Zoologiska Bidrag Uppsala 6: 183-648.

Pejler B. 1957. Taxonomical and ecological studies on planktonic Rotatoria from Central Sweden. Kungliga svenska Vetenskapsakademiens Handllingar Ser 4, 6 (7): 1-52.

Pejler B. 1997. Termlist Rotifera. Nordic Code Centre. Swedish Museum of Natural History.

Reinertsen H, Haug A, Koksvik JI. 1997. Effects of fish elimination on the phytoplankton and zooplankton in a small eutrophic lake. Verh. Internat. Verein. Limnol. 26: 593-598.

Sanoamuang L, Stout VM. 1993. New records of rotifers from the South Island lakes, New Zealand. Hydrobiologia 255/256: 481-490.

Segers H. 1993. Rotifera of some lakes in the floodplain of the River Niger (Imo State, Nigeria) I New species and other taxonomic considerations. Hydrobiologia 250: 39-61.

Segers H. 1995. The Lecanidae Monogononta. In: Dumont HJF (ed). Guides to identification of the Microinvertebrates of the Continental Waters of the World. SPB Academic Publishing bv 2: $226 \mathrm{p}$.

Segers H. 2003. A biogeographical analysis of rotifers of the genus Trichocerca Lamarck, 1801 (Trichocercidae, Monogononta, Rotifera), with notes on taxonomy. Hydrobiologia 500: 103-114.

Segers H. 2007. Annotated checklist of the rotifers (Phylum Rotifera). Zootaxa 1564: 1-104.

Segers H, Polpunthin P. 1997. New and rare Rotifera from ThaleNoi Lake, Pattalang Province, Thailand, with a note on the taxonomy of Cephalodella (Notommatidae). Annls. Limnol. 33 (1): $13-21$.

Shiel RJ, Koste W. 1983. Rotifer communities of billabongs in northern and south-eastern Australia. Hydrobiologia 104: 4147.

Shiel RJ, Green JD, Nielsen DL. 1998. Floodplain biodiversity: why are there so many species? Hydrobiologia 387/388: 39-46.

Smirnov NS. 1927. Neue und interessante Rotatoria aus dem Gouvernement Kostroma. Gidrobiol. Zurnal. 6: 224-228. (In Russian; German Summary.)

Stenroos K. 1898. Das Tierleben im Nurmijärvi-See. Acta Soc. Fauna et Flora Fennica 17(1): 1-259.

Strøm KM. 1921. The phytoplankton of some Norwegian lakes. Skrifter Videnskabsselskapet i Christiania Matematisk-naturvidenskabelig Kl. 1(4): 1-51.

Strøm KM. 1926. Norwegian mountain algae. An account of the biology, ecology and distribution of the algae and pelagic invertebrates in the region surrounding the mountaincrossing of the Bergen railway. Skrifter Videnskabsselskapet i Christiania Matematisk-naturvidenskabelig K1. 2 (6): 1-264.

Strøm KM. 1927. Plankton from Finmark lakes. Tromsø Museums Årshefter 49 (1):1-23.

Strøm KM. 1930. Limnological observations on Norwegian lakes. Archiv für Hydrobiologie 21: 97-124.

Strøm KM. 1931. Feforvatn. A physiogeographical and biological 
study of a mountain lake. Archiv für Hydrobiologie 22: 491536.

Strøm KM. 1932. Tyrifjord. A limnological study. Skrifter Videnskabsselskapet i Christiania Matematisk-naturvidenskabelig K1. 3:1-84.

Strøm KM. 1944. High mountain limnology. Some observations on stagnant and running waters of the Rondane area. Avhandlinger Det Norske videnskaps-akademi i Oslo, Matematisk-naturvitenskapelig klasse 1944(8): 1-24.

Thomasson K. 1956. Reflections on arctic and alpine lakes. Oikos 7(1): 117-143.

Varga L. 1936a. Beiträge zur Limnologie und zur Kenntnis der Rotatorien-Fauna des norwegischen Lapplandes. I. Limnologisches und Rotatorien aus der Umgebung des AltenFjordes. Archiv für Hydrobiologie 29: 130-136.

Varga L. 1936b. Beiträge zur Limnologie und zur Kenntnis der Rotatorien-Fauna des Norwegischen Lapplandes. II. Limnologisches und Rotatorien aus der Umgebung des Porsanger-Fjordes. Archiv für Hydrobiologie 30: 371-378.

Varga L. 1938. Beiträge zur Limnologie und zur Kenntnis der Rotatorien-Fauna des norwegischen Lapplandes. III. Limnologisches und Rotatorien aus der Umgebung von Assebakte. Archiv für Hydrobiologie 32: 100-114.

Voigt M. 1957. Rotatoria. Die Rädertierfauna Mitteleuropas. Berlin - Nikolassee. I, 508 p II, 115 pl.

Walsh EJ, Schröder T, Arroyo ML. 2007. How well do single samples reflect rotifer species diversity? A test based on interannual variation of rotifer communities in Big Bend National Park (Texas, USA). Hydrobiologia 593: 39-47.

Wiszniewski J. 1954. Materiaux relatifs à la nomenclature et à la bibliographie des Rotifères. Polskie Archiwum. Hydrobiologii II(XV) 2: 7-260.

Wulfert K. 1936. Beiträge zur Kenntnis der Rädertierfauna Deutschlands. II Dicranophoridae. Archiv für Hydrobiologie 30: 401-437.

Wulfert K. 1937. Beuträge zur Kenntnis der Rädertierfauna Deutschlands. III Cephalodella. Archiv für Hydrobiologie 31: 592-635.

Wulfert K. 1940. Rotatorien einiger ostdeutscher Torfmoore. Archiv für Hydrobiologie 36: 552-587.

Wulfert K. 1951. Das Naturschutzgrbiet auf dem Glatzer Schneeberg. Die Rädertiere des Naturschutzgebietes. Archiv für Hydrobiologie 44: 441-471.

Wulfert K. 1960. Die Rädertiere saurer Gewässer der Dübener Heide. I. Die Rotatorien des Zadlitzmoors und des Wildenheiner Bruchs. Archiv für Hydrobiologie 56 (3): 261-298.

Wulfert K. 1961. Die Rädertiere saurer Gewässer der Dübener Heide. III. Die Rotatorien des Presseler und des Winkelmühler Teiches. Archiv für Hydrobiologie 58 (1): 72-102.

Wærvågen SB, Nilssen JP. 2003. Major changes in pelagic rotifers during natural and forced recovery from acidification. Hydrobiologia 449: 63-82. 